Portland State University

PDXScholar

\title{
A stratigraphic and geochemical investigation of ferruginous bauxite deposits in the Salem Hills, Marion County, Oregon
}

Charles William Hoffman

Portland State University

Follow this and additional works at: https://pdxscholar.library.pdx.edu/open_access_etds

Part of the Geochemistry Commons, and the Stratigraphy Commons Let us know how access to this document benefits you.

Recommended Citation

Hoffman, Charles William, "A stratigraphic and geochemical investigation of ferruginous bauxite deposits in the Salem Hills, Marion County, Oregon" (1981). Dissertations and Theses. Paper 3201.

https://doi.org/10.15760/etd.3192

This Thesis is brought to you for free and open access. It has been accepted for inclusion in Dissertations and Theses by an authorized administrator of PDXScholar. Please contact us if we can make this document more accessible: pdxscholar@pdx.edu. 
AN ABSTRACT OF THE THESIS OF Charles William Hoffman for the Master of Science in Geology presented June 10, 1981.

Title: A Stratigraphic and Geochemical Investigation of Ferruginous Bauxite Deposits in the Salem Hills, Marion County, Oregon.

APPROVED BY MEMBERS OF THE THESIS COMMITTEE:

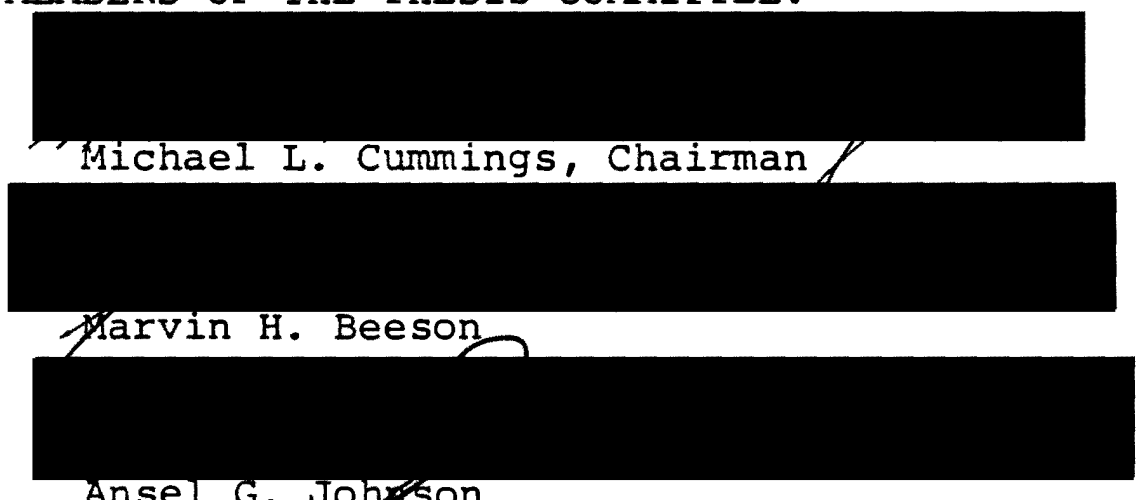

Pacific Northwest ferruginous bauxite deposits have formed in four main areas of northwestern Oregon and southwestern Washington by laterization of flows of the Columbia River Basalt Group (CRBG). The deposits, averaging 36.38 $\mathrm{Al}_{2} \mathrm{O}_{3}, 31.88 \mathrm{Fe}_{2} \mathrm{O}_{3}$, and $5.98 \mathrm{SiO}_{2}$, generally occur near the surface of hilltops in gently rolling areas. Two very different views have been advanced regarding the setting in which the deposits have formed. The first hypothesis calls for a blanket-type laterization by erosion of much of the original deposit upon uplift and dissection of the area. 
The second proposes that laterization followed uplift and only a limited amount of bauxite developed. Deposits found within the Salem Hills provide insight into this question and into questions involving the conditions under which the deposits formed and the role parent material played in controlling the distribution and composition of ferruginous bauxite. A very strong correlation, both in plan and section view, exists between the distribution of the informal Kelley Hollow flow of the Frenchman Springs Member of the Wanapum Basalt Formation and the occurrence of ferruginous bauxite. Geochemical variation for 12 major, minor, and trace elements in 3 laterite profiles is markedly greater in the weathering products of the Kelley Hollow flow than those of the underlying high Mgo Grande Ronde flow and appears to be related to structural and textural properties of the two flows. La, Sm, and Ce; Hf, Th, and Sc; and Co and MnO form three groups of elements which display sympathetic geochemical variation in concentration or depletion relative to parent material concentration within the laterite profiles. $\mathrm{Al}_{2} \mathrm{O}_{3}$ and $\mathrm{Fe}_{2} \mathrm{O}_{3}$ relative concentrations tend to vary oppositely though both are significantly concentrated in most samples. $\mathrm{SiO}_{2}$ and $\mathrm{Cr}$ variations do not relate to any of the other elements. Eh-pH equilibria for the $\mathrm{Al}-\mathrm{Fe}-\mathrm{H}-\mathrm{O}$ system suggest that $\mathrm{pH}$ within the weathering environment was generally above 3-4 but less than $8-10$ and that Eh was generally greater than 0 . Silica depletion, the key process to the 
development of these ferruginous bauxites, was dependent upon removal of leachate by ground water flushing action, a process which would presumably require topographic relief. Well developed, lateral ground water flow above a clay-rich interbed at the base of the Kelley Hollow flow further enhanced the flushing action. The deposits developed after deposition of the Kelley Hollow flow and after the development of an active ground water system in the area. The mineralogy of the laterite profiles requires a climate having alternating wet and dry seasons during the development of the deposits. The ferruginous bauxite may have been more extensive than it presently is but a blanket type laterization is not supported by the evidence produced in this study. 


\title{
A STRATIGRAPHIC AND GEOCHEMICAL INVESTIGATION OF FERRUGINOUS BAUXITE DEPOSITS IN THE SALEM HILLS, IIARION COUNTY, OREGON
}

\author{
by \\ Charles William Hoffman
}

A thesis submitted in partial fullfillment of the requirements for the degree of

MASTER OF SCIENCE

in

GEOLOGY

Portlanc State University

1981 
TO THE OFFICE OF GRADUATE STUDIES AND RESEARCH:

The members of the Committee approve the thesis of Charles William Hoffman presented June 10, 1981.

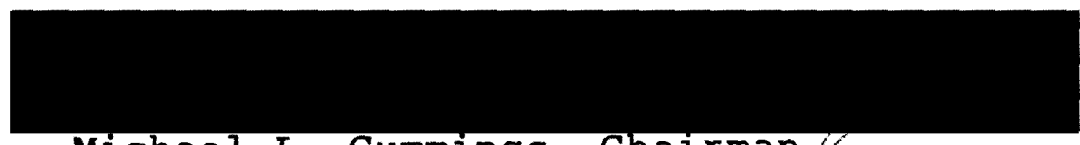

Michael L. Cummings, Chairman

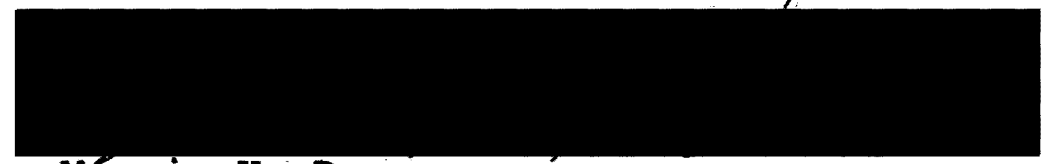

Marvin $\mathrm{H}$. Beeson

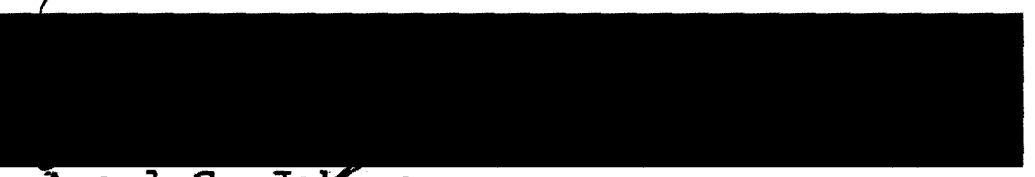

Ansel G. Jghnson

\section{APPROVED:}

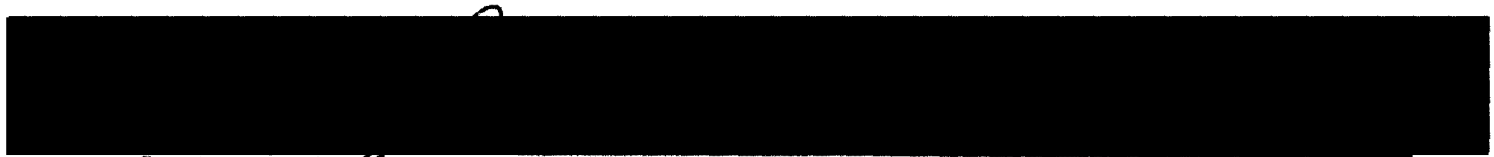

Ansel G. Johrson, Head, Department of Earth Sciences

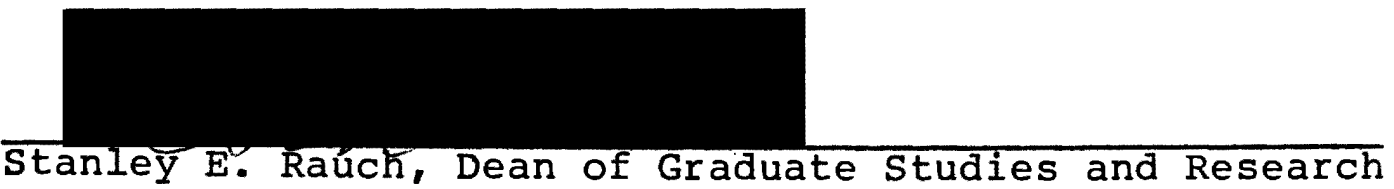




\section{ACKNOWLEDGEMENTS}

A great many people and organizations are deserving of thanks for their support, advice, and assistance in the completion of this thesis. The Oregon Department of Geology and Mineral Industries, the William Rockie Scholarship Fund of the Portland State University Earth Sciences Department, and Sigma $\mathrm{Xi}$, the Scientific Research Society provided financial assistance. Some of the field mapping and chemical analyses were completed as part of a Columbia River basalt mapping project through which I was employed by the U.S. Geological survey during the summer of 1980 . Other chemical analyses were provided by personel at the Oregon Graduate Center.

Dr. Michael Cummings has been instrumental in nearly every phase of the thesis and unending in his encouragement to complete the work in a timely manner. Dr. Marvin Beeson provided instruction in Columbia River basalt stratigraphy which was critical to the field portion of the thesis. The time investment of these two gentlemen has been great and it is something that I value highly. Dr. Ansel Johnson has provided helpful comments and advice on several occasions and freely given his time to serve as a committee member. John Hook, an authority on Pacific Northwest ferrugin- 
ous bauxite deposits, was quite helpful as well. His special knowledge of the deposits was a valuble resource. I am further indebted to many other members of the Earth Sciences Department who have aided this research in one way or another.

Finally, I would like to dedicate this thesis to my wife, Paula, whose needed support and encouragement over the past two years has been unfailing. 
TABI.E OF CONTENTS

PAGE

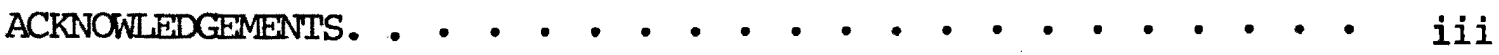

LIST OF FIGURES . . . . . . . . . . . . . . . . . viii vi

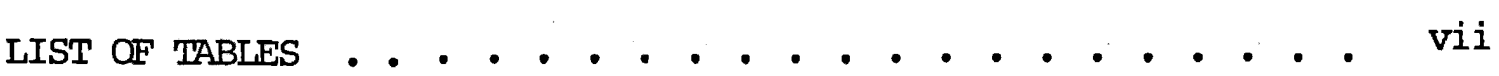

INTRODUCTION . . . . . . . . . . . . . . . 1

General . . . . . . . . . . . . 1

Physical and Cultural Setting . . . . . . . 3

Geomorphology . . . . . . . . . . . . . 4

Previous Work . . . . . . . . . . . 5

Field Work. . . . . . . . . . . . 12

Scope ................. 18

REGIONAL GEOLOGY • • • • • . • • • . • . . 19

GEOLOGY OF THE SALEM HILLS . . . . . . . . . . . . 24

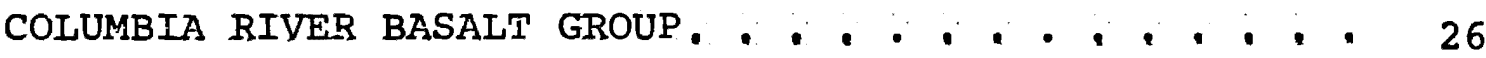

General ............... 26

Stratigraphy. . . . . . . . . . . . . 26

Grande Ronde basalt

Wanapum basalt

Basalt Geochenistry . . . . . . . . . 37

Discussion. . . . . . . . . . . . . 43 
RELATIONSHIP OF FERRUGINOUS BAUXITE TO BASALT. • • • • . 54 IATERITE AND FERRUGINOUS BAUXITE STRATIGRAPHY. • • • • 57 General •. . . . . . . . . . . . . 57 Turner Freeway Profile. . . . . . . . . . . 59 Prospect Hill Profile . . . . . . . . . . . 67 Reese Hill Profile. . . . . . . . . . . 69 Enchanted Forest Traverse. . . . . . . . . 71

GEOCHEMISTRY OF LATERITE PROFILES. • • • • • • • • . 75

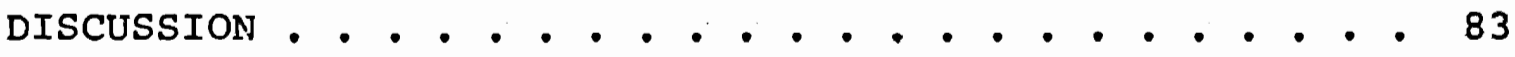
CONCLUSIONS. . • • • • • • • • • • • . • • • • . . 96 REFERENCES . . . . . . . . . . . . . . . . . . 100 APPENDIX A . . . . . . . . . . . . . . . . . 106 APPENDIX B . . . . . . . . . . . . . . . . . . 107 APPEINDIX C . . . . . . . . . . . . . . . . . 116 


\section{LIST OF TABLES}

TABLE

PAGE

I Comparison of Average Major Oxide Concentrations

for the low Mgo, high MgO, and Frenchman

Springs Chemical Types in the Salem Hills to

Average Concentrations Reported in other

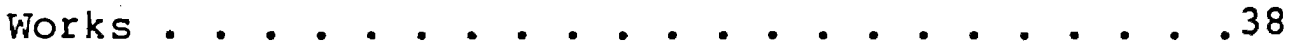

I Comparison of Average INAA Determined Fe and

Selected Trace Element Concentrations for the

low MgO, high MgO, and Frenchman Springs

Chemical Types in the Salem Hills to Average

Concentrations Reported in Other Works. . . . . . 42

II INAA Results. . . . . . . . . . . . . . . . . 110

IV INAA Standards Analyses . . . . . . . . . . . 114

V INAA Duplicate Samples Analyses • • • • • • • • 115

VI Reference Values for Bauxite Standards. • • • • 117

VII X-Ray Fluoresence Data with Comparisons to

Results of other Analytical Methods . . . . 119 


\section{LIST OF FIGURES}

FIGURE

PAGE

1. Location of Study Area and Distribution of

Pacific Northwest Ferruginous Bauxite

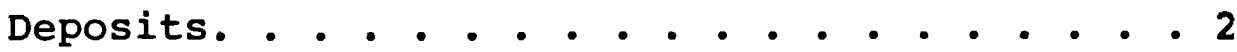

2. Grade-tonnage Estimates of Pacific Northwest

Ferruginous Bauxite Deposits. . . . . . . 10

3. Drive Core Taken as Part of Drilling Operation . . 16

4. Regional Setting of Salem Hills with Generalized

Distribution of the Columbia River Basalt Group . . . . . . . . . . . . . .20

5. Columbia River Basalt Group Stratigraphy . . . . 27

6. Columbia River Basalt Stratigraphy within the Salen Hills . . . . . . . . . . . . . 29

7. High MgO Bculders Exposed Behind Fred Meyers Department Store in Salem . . . . . . . .33

8. Baked Contact Zone Between Winter Water and High Mgo Flows Behind Southgate Shopping Center in Salem . . . . . . . . . . . . . . . 34

9. Yellowish-orange Weathered Kelley Hollow Flow overlying reddish-brown Weathered high Mgo Flow. - . . . . . . . . . . . . . . . 37 
10. Mgo Variation Diagrams for Salem Hills Columbia River Basalt Flows Compared to Average Values Determined by other Workers for the low MgO, high Mgo, and Frenchman Springs Chemical Types. . . . . . . . . . . . . . . 40

11. INAA Determined Concentrations of Selected Elements for Samples of the Three Basalt Chemical Types Found in the Salem Hills . . . . . . . . . .41 1.2a. Distribution of Unnamed Low MgO $\mathrm{N}_{2}$ Flow. . . . . .45 12b. Distribution of the Winter Water Flow. . . . . .46 12c. Distribution of the High MgO Flow. . . . . . . . .47 12d. Distribution of the Ginkgo Flow. . . . . . . . . .48 12e. Distribution of the Kelley Hollow Flow . . . . . .49 13. Comparison of Ore Thicknesses in Two Holes of Corcoran and Libbey (1956) and the Reese Hill Profile Hole of this Stuày . . . . . . . .58

14. Generalized Ferruginous Bauxite Stratigraphy . . . .60 15. Turner Freeway Laterite Profile. . . . . . . . . 61 16. "Draping" of Redaish-brown Horizon in a Roadcut on the East Side of I-5 just South of the Sunnyside Interchange. . . . . . . . . 63

17. Weathered Pillows at Base of Kelley Hollow Flow Along I-5 Frontage Road just South of Sunnysicie Interchange. . . . . . . . . . . . 65 
18. Clay-filled Fractures in Basaltic Corestone From the High Mgo Flow of the Turner Freeway Profile. . . . . . . . . . . . . 66

19. Prospect Hill Laterite Profile. . . . . . . .68

20. Reese Hill Laterite Profile. . . . . . . . . 69

21. Enchanted Forest mraverse Sampling Scheme and

Major Oxide Concentrations . . . . . . . .72

22. Vesicular Seprolite of Enchanted Forest mraverse • .74

23a. Turner Freeway Geochenical Profile . • • • . . 76

23b. Prospect Hill Geochemical Profile. . . . . . . . .77

23c. Reese Hill Geochenical Profile . . . . . . .78

24. Eh-pH Stability for the Systems F-O-H and Al-0-H . .86

25. Combined Diagrams of Figure 24. . . . . . . . . 86 


\section{INTRODUCTION}

\section{GENERAL}

Ferruginous bauxite deposits have developed in southwestern Washington and northwestern Oregon by laterization of flows of the Miocene Columbia River Basalt Group. These deposits occur in the upland areas of gently rolling terrain in Marion, Multnomah, Washington, and Columbia Counties, Oregon, and Cowlitz and Wahkiakum Counties, Washington. This study mainly concerns those deposits located in the Salem Hills, Marion County, Oregon, which comprise parts of the U.S.G.S. Rickreal, Salem West, Salem East, Monmouth, Sidney, Turner, and Crabtree 7-1/2 minute quadrangle maps. A large part of the thesis area lies within T.8 S., R. $3 \mathrm{~W}$. of the Willamette Meridian (Figure 1).

The term "ferruginous bauxite" was applied to the high-iron, high-aluminum laterites of the Pacific Northwest by Libbey, Lowry, and Mason (1945). "Laterite", which is a highly weathered, red subsoil rich in secondary oxides of iron or aluminum (or both) and nearly devoid of alkalies and primary silicates, was deemed too general a term because it lacked specific mineral connotation. 


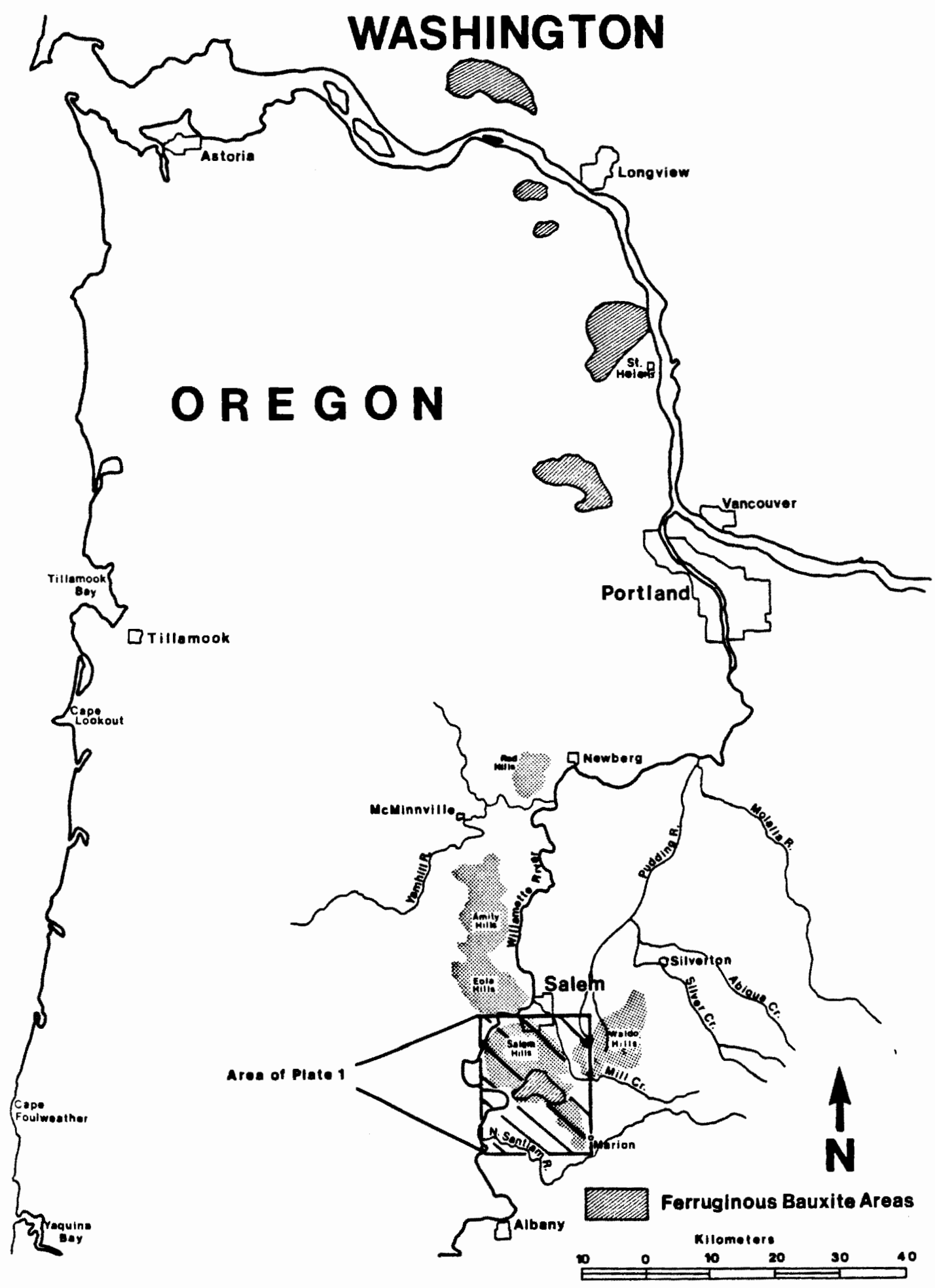

Figure 1. Location of study area and distribution of Pacific Northwest ferruginous bauxite deposits (distribution date after Hook, 1976). 
The abundance of the bauxite minerals gibbsite and boehmite, usually in excess of the hydrous iron oxides, was cited to justify the use of "ferruginous bauxite".

The term "ore" has been used in an informal sense by several previous workers in referring to zones within the ferruginous bauxite having greater than $30 \%$ alumina and less than 108 silica (Jackson, 1971). Exploration drilling, primarily by Alcoa and Reynolds Metals Company, has yielded an estimate of 56 million long dry tons of ore, averaging $36.268 \mathrm{Al}_{2} \mathrm{O}_{3}, 31.778 \mathrm{Fe}_{2} \mathrm{O}_{3}$, and $5.90 \%$ $\mathrm{SiO}_{2}$ (Hook, 1976).

\section{PHYSICAL AND CULTURAL SETTING}

The climate in the Salem area is temperate with mild rainy winters and comparatively dry summers. Mean annual rainfall and temperature at Salem are $101.1 \mathrm{~cm}$ and $11.7^{\circ} \mathrm{C}$, respectively. Most of the annual precipitation occurs during the five month period of November through March with only 68 falling during the three summer months. Nearly all of this precipitation falls as rain with, on the average, only three to four days of the year having measurable amounts of snowfall. The seasonal temperature range is about $15.5^{\circ}$ from a monthly low of $3.8^{\circ}$ in January to a monthly high of $19.2^{\circ}$ in July (NOAA, 1979). 
A general cooling and drying climatic trend, common to much of North America, has been shown to have occurred in Oregon since Eocene time (Chaney, 1948; Durham, 1950).

Most of the deposits in the Salem area are located outside of the Salem city limits in areas which are primarily in agricultural use. This picture is changing, however, and will probably continue to change as growth pressures push development farther south. Certainly a growing percentage of this resource will become unavailable for potential development as urban and suburban expansion proceeds.

\section{GEOMORPHOLOGY}

The Salem Hills are part of the Eola geomorphic unit, a northwesterly to northerly trending topographically high area within the Willamette Valley. The Eola surface is the oldest geomorphic surface within the willamette valley and is represented by crests and upper parts of the Salem Hills, Waldo Hills, Eola Hills, Red Hills of Dundee, and the unnamed hills in the vicinity of Lacomb (Balster and Parsons, 1968). Mill Creek, to the east, and the Willamette River, to the west and northwest, separate the Salem Hills from the Waldo Hills and the Eola Hills, respectively. 
Up to 125 meters of Columbia River Basalt flows form a resistant cap for the Salem Hills. A steep scarp, very prone to landsliding in the past, has developed on the west side of the upland where the Willamette River has eroded into marine sedimentary rocks underlying the basalts.

Maximum elevation within the thesis area is 342 meters at Prospect Hill along the western margin of the area. The average topographic relief from the ridge that defines this margin to the river level below is about 260 meters. The gentle $\left(1-2^{\circ}\right)$ northeastward slope from the western margin is very nearly a dip slope of the capping basalt. The general rolling character of this surface is more likely attributable to erosional effects rather than geologic structure. Several streams, Rodgers Creek and Battle Creek in particular, have cut well developed valleys into the Salem Hills.

\section{PREVIOUS WORK}

The first comprehensive report on Pacific Northwest ferruginous bauxite deposits was a reconnaissance investigation of northwestern Oregon deposits by Libbey, Lowry, and Mason (1945) of the Oregon Department of Geology and Mineral Industries (DOGAMI). Stratigraphic sections of 
mineralogic and major element chemistry profiles were developed for ferruginous bauxite localities throughout their known occurrences in Oregon. A major difference in the stratigraphy of the laterites was noted between the two main areas, Marion County and Columbia County. The southern occurrences tend to lack an solitic or pisolitic horizon within the bauxite profile while they contain a relative abundance of hard gibbsitic nodules as float material.

Libbey, Lowry and Mason hypothesized that the ferruginous bauxite developed after the last outpouring of basalt and prior to epierogenic uplift of the region, which they believed occurred in the Pliocene epoch. Thus the deposits were viewed as being essentially erosional remnants of a once much more extensive laterite horizon.

The initial report of potentially economic bauxite deposits in the Pacific Northwest stimulated further investigation by government and private industry. The U.S. Geological Survey, U.S. Bureau of Mines, and the State of Oregon sponsored additional work during 1945 and 1946. Alcoa Mining Company undertook an exploration program, the results of which were later acquired by Reynolds Metal Company. 
In 1948, Victor T. Allen published a petrographic study on the formation of bauxite from basalt in which he concluded that the ferruginous bauxite was the result of a two-stage weathering process. The first stage involves the transformation of the primary basalt minerals to alumina or iron clays such as kaolinite, halloysite, or nontronite. In the second stage, silica is leached from the upper portion of the clay section to yield the primary bauxite mineral, gibbsite. Allen studied samples from an Alcoa Mining Company hole drilled to 60 meters and analyzed for $\mathrm{Al}_{2} \mathrm{O}_{3}, \mathrm{Fe}_{2} \mathrm{O}_{3}, \mathrm{SiO}_{2}$ and $\mathrm{TiO}_{2}$ on 0.6 meter intervals.

Work by DOGAMI geologists continued in 1953 and 1954 with a shallow drilling and hand augering program in the Salem Hills. The U.S. Bureau of Mines laboratory in Albany, Oregon cooperated in the study. The findings were published in 1956 by Corcoran and Libbey. The Waldo Hills and Eola Hills were summarily investigated but the widely scattered and apparently lean deposits of these areas failed to warrant drilling. This study tended to examine the laterites more from a geochemical rather than a mineralogical standpoint as compared to previous studies and one improtant observation was that the upper portions of Salem Hills laterites, in apparent contrast to those of Columbia 
County, tend to be more ferruginous than the lower portions.

Corcoran and Libbey proposed their genetic model largely from work done by Sherman (1949) on the formation of laterites from Hawaiian basalts. Sherman contended that low-iron bauxites (aluminous laterites) are formed in areas having a continuously wet climate and ferruginous laterites are formed as a results of alternating wet and dry seasons because, in the later case, iron and titanium oxides will concentrate in the upper portions of the weathering profile through capillary action. Corcoran and Libbey, citing the fact that Oregon's paleoclimate was warmer and wetter, hypothesized that it was "possible that a sufficient amount of rainfall occurred throughout the year during the early laterization of the basalt to cause the formation of a fairly thick section of low-iron bauxite." Later, with a change to an alternating wet and dry climate, "the upper part of the remaining original bauxite section in the zone of seasonal dehydration became more ferruginous".

Deposits in southwestern Washington were investigated by Livingston (1966) for the Washington Division of Mines and Geology. This report suggests that the onset of laterization was shortly after the final basalt deposition and that it probably continued until the area was covered 
by a 15- to 20-meter thick mantle of silt (loess) during the early to middle Pleistocene. Livingston cited an angular unconformity between silt and the underlying bauxite as being indicative that epierogenical uplift preceeded the silt deposition but he does not exclude the possibility that laterization is an ongoing process.

In 1970, Reynolds Metal Company's exploration efforts culminated with the mining of a 45,000-metric ton plant-run sample from a number of pits at several different bauxite localities. Ron Jackson, a Portland State University graudate student working closely with Reynolds geologist John Hook, was afforded several unparalleled ferruginous bauxite exposures. He reported his observations in a short paper in The ore Bin (1971) and in an unpublished Master's Thesis (1974). Unfortunately for geologists interested in the Pacific Northwest laterites, the sample sites were filled and recontoured shortly after the bulk samples were recovered.

Hook (1976), utilizing previously confidential company information, compiled an excellent overview of the ferruginous bauxites. His report included area-by-area grade and tonnage estimates (Figure 2 ) and a generalized laterite stratigraphic section. The section consisted of essentially four main zones, the relict basalt, finegrained, nodular and pisolitic zones. The relict basalt 


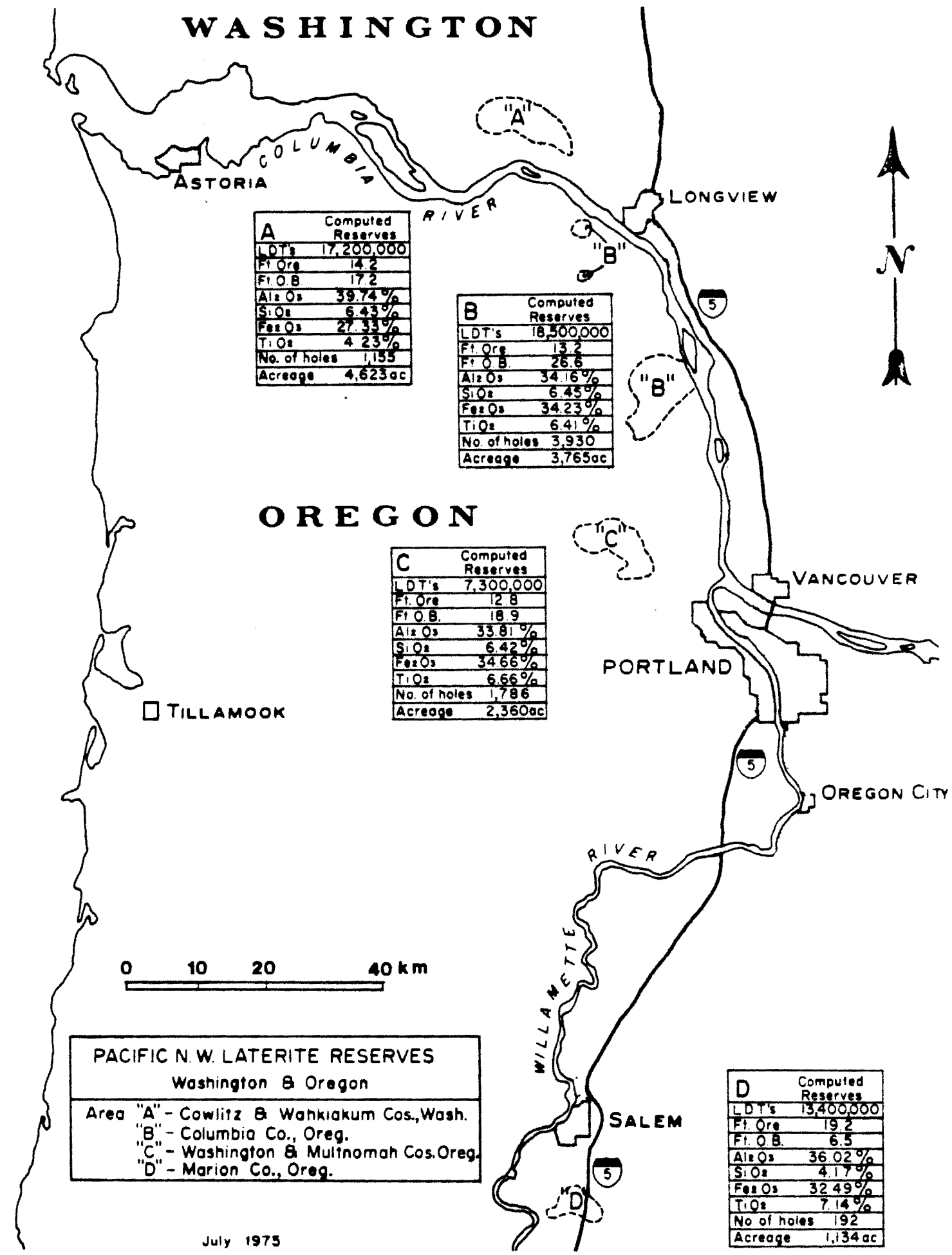

Figure 2. Grade-tonnage estimates of Pacific Northwest ferruginous bauxite deposits (after Figure 1 of Hook, 1976). 
zone grades upward from slightly weathered material to varicolored soft clay with relict basalt texture. The overlying fine-grained zone retains no relict texture and consists of gibbsitic clay and magnetite, which are also abundant in the overlying nodular zone that contains scattered hard gibbsitic nodules and fragments in the clay matrix. The pisolitic zone is of uncertain origin and contains friable bauxitic clay and pisolites or oblites composed of iron or iron/titanium oxides.

A significant aspect of the Hook report was his alternative hypothesis to the origin of the ferruginous bauxites. He proposed that the development of bauxite was in response to the development of youthful topography on the basalt. Hook observed that the depth of laterization and the grade of bauxite seemed to increase down valley in the Mill Creek drainage system of Wahkiakum County, Washington and that low-silica bauxites occurred only on the lower portions of the slope, where dissection was greatest, rather than on the upland portions of the area.

A major difference therefore exists between Hook's hypothesis and the blanket hypothesis subscribed to by previous workers. The implications of this difference bear considerable importance in terms of the potential distribution of the deposits. Ideas held by the various 
investigators as to the process that formed the ferruginous bauxites do not contrast as sharply. A two-stage process involving an initial breakdown of basalt to kaolinitic clays, which are then leached of their silica to yield bauxitic clays, is generally accepted by all previous workers. Corcoran and Libbey add percolation of iron into the upper portions of the section as a third step.

\section{FIELD WORK}

Field work for this study was conducted during the late summer and early fall of 1980. The first part of the summer was spent investigating the stratigraphy and structure of the Columbia River Basalt Group (CRBG) in other areas of western Oregon with Dr. Marvin Beeson as part of a U.S. Geological Survey preliminary reconnaissance CRBG mapping project under Interagency Agreement No. EW-78I-06-1978 with the U.S. Department of Energy.

Basalt was sampled during the field study in an effort to gain maximum stratigraphic control. Hand sample specimens and chips for geochemical analysis were collected from available exposures. The center portion of a flow was the sampling target, however, this objective was often compromised because of incomplete or weathered exposure. Due to the advanced weathering of the basalts, spheroidal boulders were often the only solid rock available for 
sampling. The interiors of these spheroids usually contains fresh basalt. Such spheroids would usually be isolated in a clay matrix, so knowing how close they were to being in place was often difficult. With experience though, and increasing control from good exposures, I developed a better base from which to make assumptions concerning the float materials. In fact, much was learned about the weathering products and the relative size and shape of the weathering spheroids proved to be useful field identification tools.

As would be expected in an area of such limited exposure, tectonic structures are difficult to discern in the field. Aside from a few apparent dip readings, attitudes were not measurable. Faults were not observable although stratigraphic correlation dictated displacement along certain linear features.

Laterite was sampled by power augering and by HQ wireline core drilling, both of which were executed with a truck mounted State of Oregon Highway Department rotary drilling rig. The drilling goal was to recover complete core sample from surface through the laterite zone to fresh basalt for the purpose of petrographic, mineralogical, and geochemical analysis. The limiting constraint on the achievement of this goal was a budget that allowed for only two days of rig rental. 
Three drill sites were selected on the basis of accessibility and stratigraphic control (Plate 1). Drill stie \#l was located near Rainbow Lane on Reese Hill in the SW $\frac{1}{4}$ SW $\frac{1}{4}$ sec. 22, T.8 S., R. 3 W., between holes \#23 and \#27 of Corcoran and Libbey (1956). The basalt stratigraphy of the site was well known from mapping and the presence of ferruginous bauxite was indicated by the previous study. Thus, I would be able to compare the laterite to its parent material and also compare my results to those of the previous investigation. Unfortunately, coring proved to be only moderately successful in terms of sample recovery and nearly prohibitive in terms of time. The main problem was that lateritic clays plugged the core barrel and caused the section below to be washed out of the hole rather than taken into the barrel. The net result was about a $40 \%$ core recovery over a total depth of about 14 meters in one work day. Nevertheless, the core recovered did prove useful in the study.

Power augering was chosen as the sampling method for the next day in order to gain drilling speed but at the expense of being able to see basalt textures. Drillsite \#2

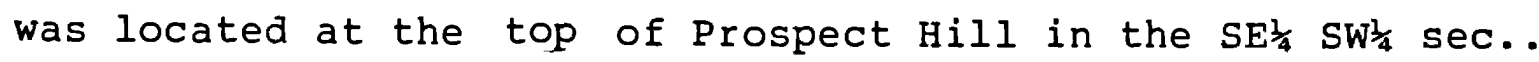
24, T.8 S., R.3 W. The presence of gibbsite nodules and the Corcoran and Libbey report indicated the presence of laterite although the previous workers did not find 
favorable concentrations of alumina or silica or both to warrant calling the laterite a ferruginous bauxite. Such a non-ore profile was desirable for the purpose of comparing a bauxitic laterite to a non-bauxitic one. Also I had a question as to which particular basalt flow capped this ridge and was curious as to whether I would be able to determine such information from laterite sampling. The augering proved to be a quick and reliable method of sampling. Approximately 12 meters of hole was drilled in just a few hours. By continuing to rotate the auger after each section was fully extended loose cuttings and cave in material was cleaned out of the hole in order to protect against mixing of samples from different zones. For particularly interesting zones the augering steel could be pulled out of the hole and replaced by a regular drill string with a split-core barrel attached at the bottom. A heavy weight would then be dropped repetitively on the upper end of the drill string, thus driving the coring tool into the next one-half meter of section at the bottom of the hole. Upon its return to the surface the core barrel would be opened longitudinally to yield a several centimeter diameter core (Figure 3 ). Five such cores were taken in holes \#2 and \#3. 


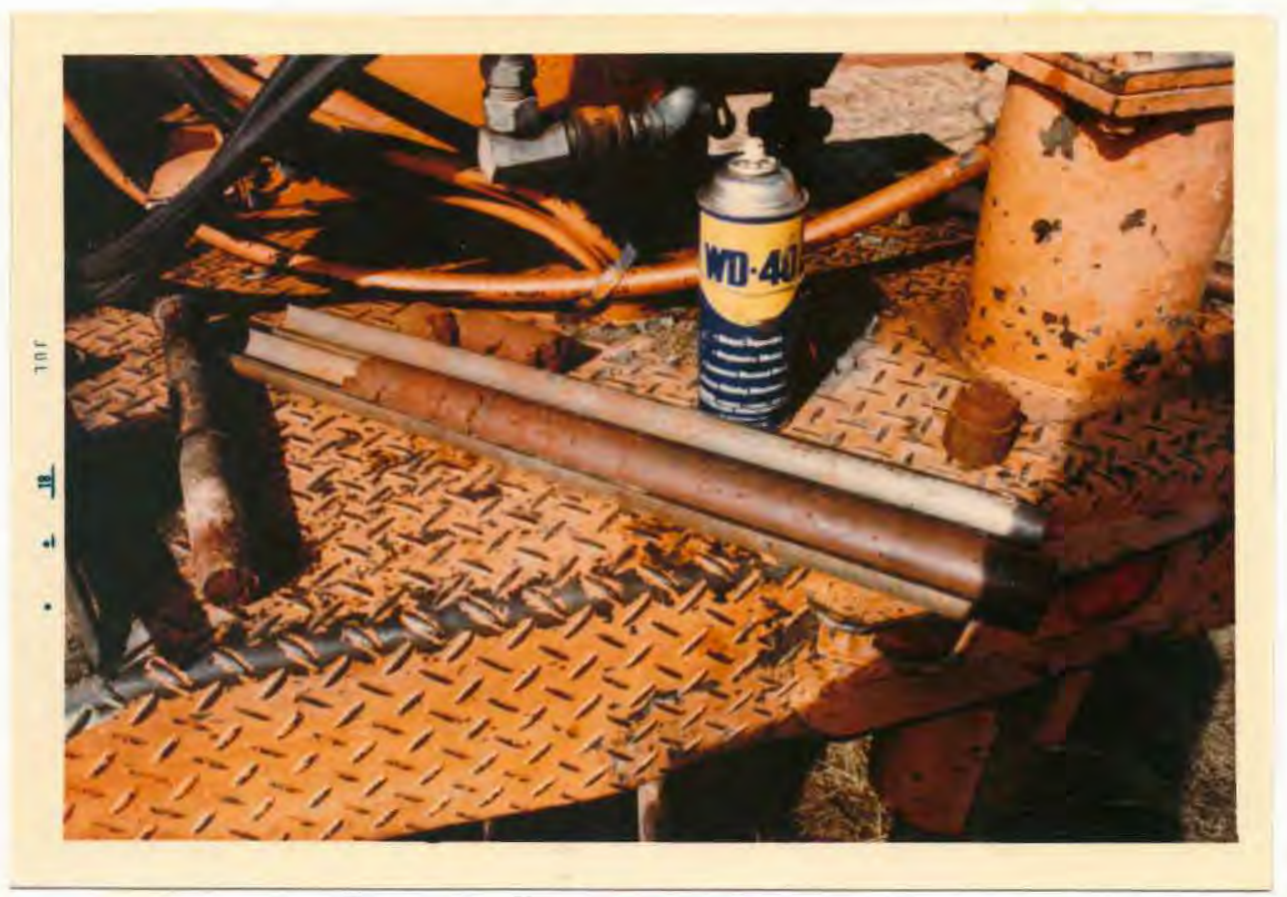

Figure 3. Drive core taken as part of drilling operation.

Drill site \#3 was located on the eastern edge of Interstate 5 right-of-way adjacent to the Turner Freeway Baptist Church just south of the Sunnyside highway exit. This is in the SW $\frac{1}{4}$ SW $\frac{1}{4}$ sec. 25, T. 8 S., R. 3 W. Fresh cuts into this hillside for I-5 construction had exposed a laterite profile during mid-summer. The total thickness of the exposure approached 40 meters and it encompassed a deep reddish-brown zone at the top that graded downward into varicolored clays and a weathered basalt zone consisting of scattered, fractured, medium-gray boulders in a varicolored clay matrix. Corcoran and Libbey did not sample this hilltop, so the quality of the laterite was not known. For this reason and for lack of access to another drill site it was 
decided to sample this lateritic horizon. Total auger depth was just over 25 meters, but sample recovery was poor below about 16 meters, where a water saturated zone was encountered. The lower part of this section was sampled via a traverse among the construction activity in progress at that time.

Finally, a lateral sampling traverse was made along a contact zone exposed on the east side of the upper level of the parking lot of the Enchanted Forest roadside attraction on I-5 about 1.75 kilometers south of the sunnyside exchange. At this locality, a vesicular saprolite is overlain by a reddish-brown soil. The upper material penetrates downward into the saprolite along fractures. Three samples, on a 10meter horizontal spacing, were taken in the upper zone about 1 meter above the interface. A fourth soil sample was taken about 1-1/2 meters below the interface in one of the thicker fracture zones. The purpose of this traverse was to evaluate the lateral chemical variability of weathered materials.

A total of 37 basalt and 44 weathered basalt samples were collected from sparse outcrops and quarries and approximately 52 meters of core drilling or power augering. The ultimate objective of obtaining a complete stratigraphic section from ferruginous bauxite down through a transitional 
relict basalt zone and into fresh basalt was not achieved. To do so would have probably required some kind of drive core capability in the laterite section and several days to core through to fresh basalt, neither of which was available to this project.

\section{SCOPE}

This study will relate Columbia River Basalt Group stratigraphy to the distribution of ferruginous bauxite deposits within the Salem Hills and examine the behavior of selected elements and minerals within the laterite profile. The physiochemical conditions of laterite profiles, the role of parent material, and some possible controls in ferruginous bauxite development will be interpreted from the primary data. Instrumental Neutron Activation Analysis (INAA) for selected minor and trace element concentrations, $x-r$ ay fluoresence for selected major element concentrations, and $x$-ray diffraction for minerology are the main analytical techniques employed. 


\section{REGIONAL GEOLOGY}

The Salem Hills are within the willamette Valley, the southern portion of a north-south trending lowland that extends from the San Juan Islands of northwestern Washington to the junction of the Cascade Range, Coast Range, and the Klamath Mountains of southern oregon. The Willamette Valley is a structural depression, the nature of which is uncertain due to extensive Quaternary cover, that lies between the Cascade Range and the Coast Range of Oregon (Figure 4). The valley, which heads near Eugene, is drained by the Willamette River which flows northward approximately 200 kilometers to its confluence with the Columbia River.

The willamette Valley is divided into two physiographic sections by the Salem Hills. The lower section of the valley is typified by areas of moderate relief separating alluvium filled basins and by relatively greater incision by the willamette River and its tributary streams. South of the Salem Hills the upper Willamette valley is characteristically of lower relief versus the northern valley except where the valley begins to narrow toward its head (Baldwin, 1981). 


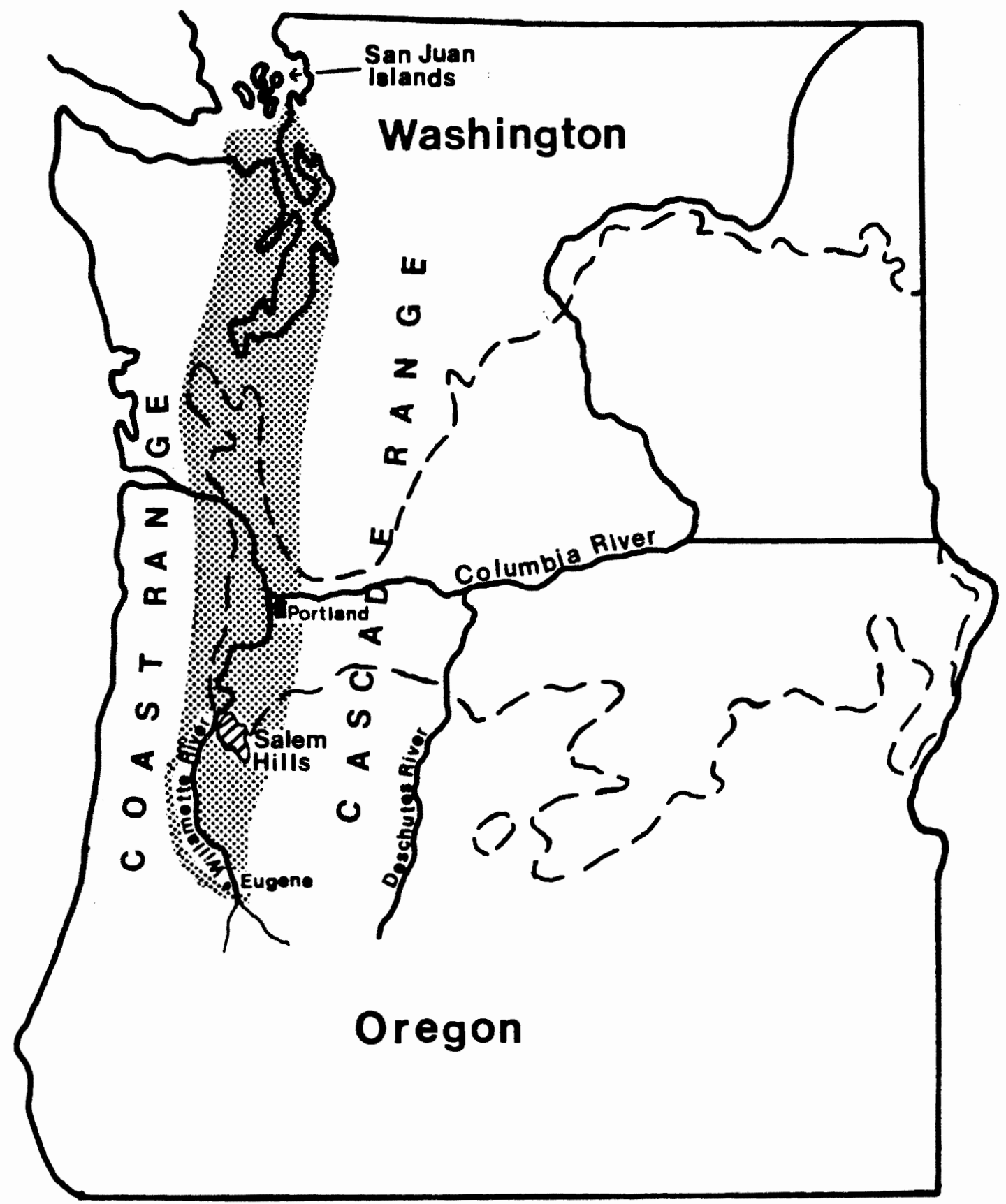

Puget-Willamette Trough

$\checkmark \sim$ Approximate extent of Columbia River Basalt Group (Waters,1961; Swanson and others,1979)

Figure 4. Regional setting of Salem Hills with generalized distribution of the Columbia River Basalt Group. 
The oldest rocks exposed in the Willamette Valley are early Eocene submarine volcanics known as the Siletz River Volcanics (Snavely and Baldwin, 1948). They occur along the central-western margin of the Willamette Valley. Middle Eocene submarine sedimentary rocks of the Flournouy Formation overlie the Siletz River Volcanics and extend southward to the Eugene area. In the southern part of the valley these formations presumably extend beneath the valley toward the margin of the Cascade Range (Baldwin, 1981) where they are overlain by late Eocene marine and nonmarine sedimentary rocks of the Spencer and Fisher Formations. In the northern portion of the willamette valley the late Eocene is represented by a sequence consisting of marine to nonmarine sedimentary rocks of the Yamhill, Cowlitz, and Keasey Formations and the Goble Volcanics.

The Oligocene formations of the Willamette valley include the Pittsburg Bluff Formation in the north and the Eugene Formation in the south. Both are marine sedimentary units which include substantial tuffaceous materials. The Eugene Formation is intruded by a number of sills of dioritic to basaltic composition that are believed to be latest Oligocene in age. The Pittsburg Bluff Formation is overlain in the northern part of its extent, in northwestern Oregon, by the Scappoose Formation, a unit generally believed to be late oligocene in age. Recent 
work by Kelty (oral communication), however, has discovered middle Miocene Columbia River Basalt Group clasts in channels within Scappoose Formation beds, thus indicating a possible younger age for this unit.

Early Miocene marine sedimentary rocks, which crop out near Scotts Mills, and limestone, near Marquam, have been interpreted to indicate that "Oligo-Miocene seaways evidently extended through southwestern Washington into the Willamette Valley" (Baldwin, 1981). These seaways may have persisted well into the Miocene as evidenced by a marine interbed in 14 - $16 \mathrm{~m} \cdot \mathrm{y}$. old Columbia River Basalt Group flows in the Amity Hills (Beeson, oral communication).

Middle Miocene flows of the Columbia River Basalt Group were erupted from fissure systems in eastern Oregon, western Idaho, and southwestern Washington from about 16.5 to 6 million years ago with the most voluminous sections being erupted between about 16 and 14 million years ago (Watkins and Baksi, 1974, Mckee and others, 1977). The Columbia River Basalt Group entered the Willamette Valley province from the Columbia River Plateau through a northeasttrending structural low in the ancestral Cascade Range that apparently extended from the present Clackamas River drainage on the south to the present Columbia River Gorge 
on the north (Beeson \& Moran, 1979; Beeson and others, in prep).

Reconnaissance mapping of the Columbia River Basalt Group in western oregon by Beeson, Tolan, and the author for the U.S. Geological Survey has produced a wealth of new information regarding the history of the Columbia River Basalt Group. Highlights of this information which pertain to this study are given in the following section. The U.S.G.S. open-file report with map should be published following the 1981 field season (Swanson, oral communication). Within the Willamette Valley, Columbia River basalt caps hills and underlies younger alluvial and lacustrine deposits from Portland to as far south as the scio area. Basalts previously mapped as Columbia River Basalt Group in the Albany, Lebanon, and Sweethome areas (Wells and Peck, 1961) have proven not to be of the Columbia River Basalt Group.

Post Columbia River basalt deposits within the Willamette Valley are predominately stream alluvium and lacustrine. Thick accumulations of these materials filled basins in the lower valley and veneered older rocks in the upper valley. 


\section{GEOLOGY OF THE SALEM HILLS}

The oldest rocks exposed in the study area are marine sedimentary rocks consisting of medium-grained tuffaceous sandstone with some intercalated beds of coarser tuff (Baldwin, 1981). These rocks are considered by Baldwin (1981) to be of equivalent age to the Keasey Formation and to be overlain by the Eugene Formation, a sequence of fossiliferous, marine, tuffaceous sandstone and siltstone. Schlicker and Deacon (1968) in a map of the geology and surficial deposits of Marion County did not differentiate Eocene-oligocene marine sedimentary rocks.

The best exposures of the Eugene Formation within the Salem Hills are on the steep scarp which is formed along the southwestern and western margin of the area as a result of erosion by the willamette River and along the western side of I-5 just north of the Jefferson exchange. The beds dip between 5 and 13 degrees northward within these exposures.

Flows of the Columbia River Basalt Group unconformably overlie the Eugene Formation and are the uppermost unit of the geologic section in the Salem Hills. The average thickness of basalt is approximately 125 meters. The basalt dips 
at an average of 2-3 degrees to the northeast in the main section of the Salem Hills and then flattens and thickens slightly in the northeast section.

Drill hole data (Schlicker and Deacon, 1968) from the general area and my own structural interpretation agree with Thayer's (1939) conclusion that the Salem Hills are essentially a homocline dipping to the northeast. The strike varies systematically from about $\mathrm{N} 40^{\circ} \mathrm{W}$ to $\mathrm{N} 20^{\circ} \mathrm{W}$ from the southern to the northern parts of the Salem Hills.

A number of faults have been interpreted in the Salem Hills on the basis of basalt stratigraphy (Plate 1). Inferred vertical displacements range from about 15 to 30 meters (mapping resolution is near the lower end of this range). These faults apparently control most of the drainage development within the area. Direct observation of faulting is everywhere obscured by weathering or vegetation. 


\section{COLUMBIA RIVER BASALT GROUP}

\section{GENERAL}

Extensive data, gathered and interpreted by a great number of workers over many years, has led to the evolution of a detailed CRBG stratigraphy which was presented by Swanson and others (1979). Figure 5 summarizes the stratigraphic relationships of the various formal CRBG units and informal units mapped in this study.

The five formations and the many members as well as many other informal units may be distinguished on the basis of lithology, jointing characteristics, magnetic polarity, and geochemistry. Only flows belonging to the Yakima Basalt Subgroup are known to occur in western Oregon (Beeson and Moran, 1979).

\section{STRATIGRAPHY}

Within the Salem Hills a total of 6 flows, all belonging to either the Grande Ronde Basalt Formation or the Frenchman Springs Member of the Wanapum Basalt Formation, occur. The total thickness of the composite section is estimated to be approximately 200 meters, not counting a Frenchman Springs intracanyon flow. The most flows 


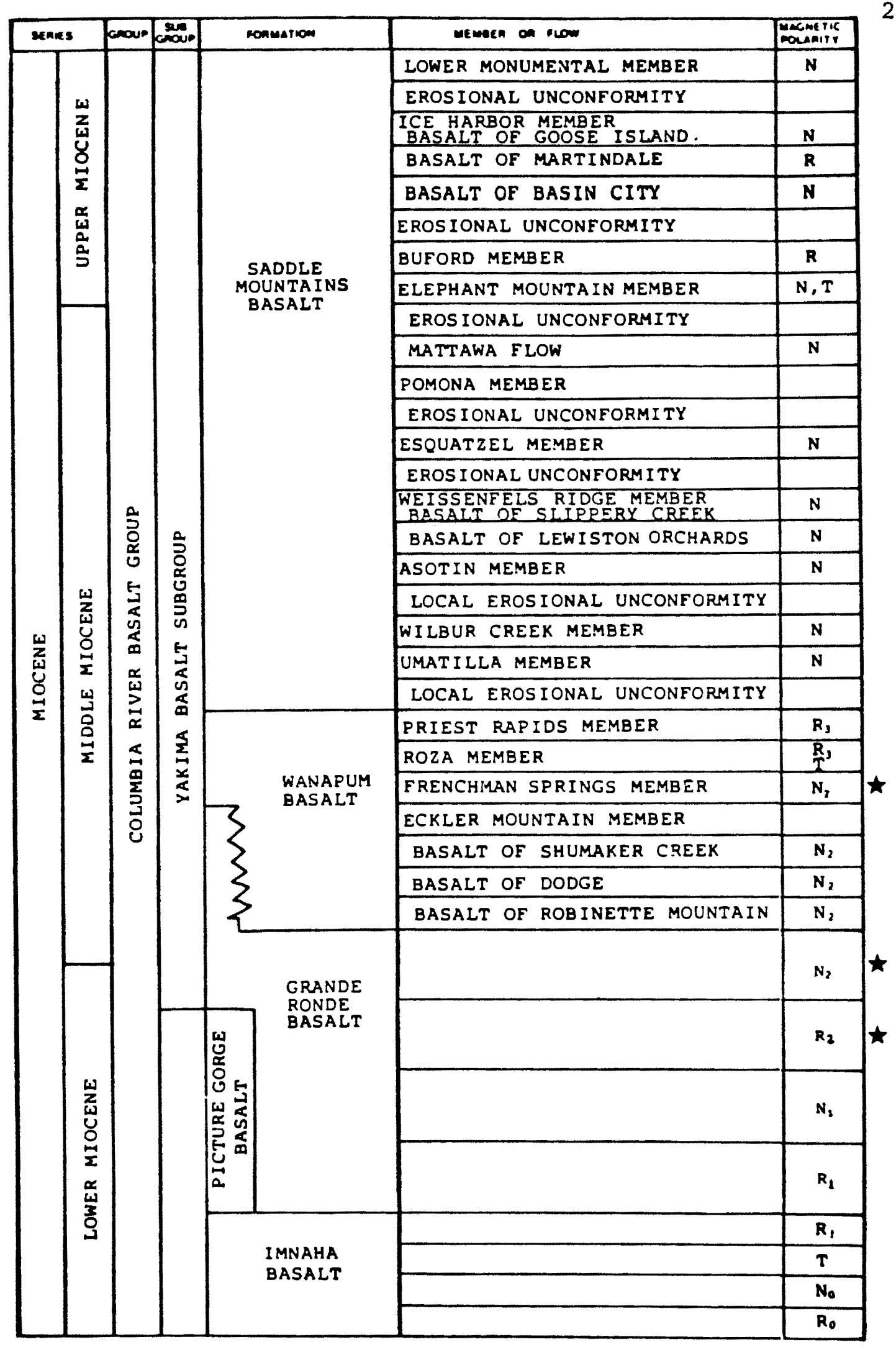

Figure 5. CRBG stratigraphy (Swanson et.al.,1979), starred units are present in the salem Hilis 
occurring within section at any one place is four. Figure 6 shows the Salem Hills basalt stratigraphy along with identification keys. Plate 1 will be a useful reference throughout the remainder of this section.

\section{Grande Ronde Basalt}

As is common throughout most other areas covered by the CRBG, the Grande Ronde basalt accounts for most of the section. Both the $R_{2}$ and $\mathrm{N}_{2}$ magnetostratigraphic units (Swanson and others, 1979) are recognized on the basis of flux-gate magnetometry in the field.

The $R_{2}$ unit is represented by a single flow that is exposed in the southeastern portion of the map area in a cut approximately 200 meters from the upper terminus of Centerwood Road within a new, unnamed housing subdivision off Parrish Gap Road. The exposure consists of moderately weathered, hackly entablature approximately 10 meters thick. The inferred total thickness of the unit is 15 meters based on the location of an exposure of older sedimentary rocks in another cut a short distance down slope from the basalt outcrop. The basalt-sediment contact is not exposed. The $R_{2}$ flow is black, fine-grained, and aphyric and has a strong reversed polarity. This flow can be classified as a low Mgo chemical type, an informal subdivision of the Grande Ronde Basalt on the basis of MgO content. 


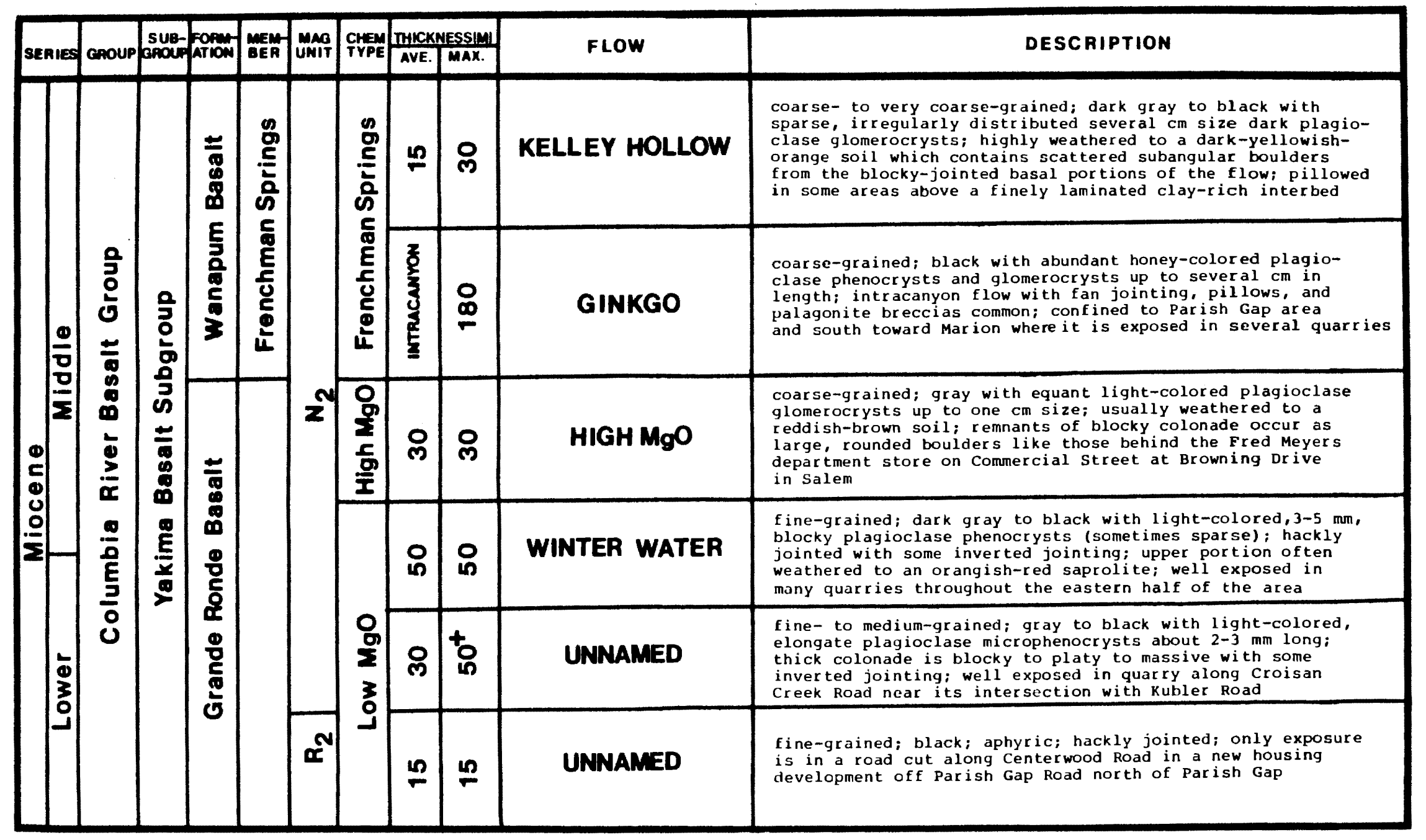

Figure 6. Columbia River Basalt Group stratigraphy within the Salem Hills. 
The $\mathrm{N}_{2}$ magnetostratigraphic unit is exposed throughout the study area. Its Grande Ronde portion can be subdivided into 3 informal, mappable units on the basis of major element chemistry, lithology, and/or jointing characteristics. The major subdivision is into high Mgo and low MgO chemical types (Wright, Groiler, \& Swanson, 1973; Beeson \& Moran, 1979; Swanson and others, 1979; Bentley and others, 1980).

Within the $\mathrm{N}_{2}$ Grande Ronde section the low Mgo type consists of two flows. The lower flow is best exposed in the northwestern part of the area in a quarry along croisan Creek Road about 500 meters south of Kubler Road. Approximately 50 meters of this flow is exposed here. Light colored, elongate plagioclase microphenocrysts, 2-3 mm long, set in a fine-to medium-grained gray to black matrix characterize the flow within the area. The jointing patterns vary markedly within the quarry exposure and among different outcrops. Jointing in the lower part of the flow varies from blocky to massive to platy. Grain size is slightly coarser and the color is generally lighter gray in the lower portions of the flow. The flow grades upward to a fine-grained, dark gray to black entablature with some inverted jointing being exhibited in the upper several meters. The flow is not exposed to the east and south of this area except where it is upfaulted along Rodger's Creek in the east central portion of the study area and where 
it occurs as a thin unit above the $R_{2}$ flow in the vicinity of Parrish Gap. The distribution and varied thickness of the first low Mgo type flow has apparently been controlled by an older topographic high that crops out below and along the margin of the basalt throughout the southern part of the area.

Overlying this high of marine sedimentary rocks and the first low MgO flow is a second low Mgo type flow. The stratigraphic position of this flow, just below the low MgOhigh Mgo chemical discontinuity and its distinctive, blocky, light colored plagioclase phenocrysts (about 3-5 mm) set in a dense, fine-grained dark gray to black matrix, correlate with the informal Winter Water flow (Powell, 1978; Bentley and others, 1980). The winter water is a relatively uniform 50 meters thick throughout the study area but it also thins and laps out against older sedimentary rocks to the south as can be seen in the I-5 highway cut approximately 5-1/2 kilometers south of the Sunnyside exchange. Numerous quarries throughout the Salem Hills area are developed in this predominately hackly jointed flow. In some exposures the jointing is blocky, either toward the base or at the top or both. This inverted jointing habit is well exposed in a rock quarry just west of the community of Turner. The upper portions of the Winter Water flow are often weathered to an 
orangish-red saprolite with relict basalt textures, especially vesicular texture, being preserved.

One flow of the high Mgo chemical type overlies the winter water flow. It is as widely distributed as the winter Water flow and maintains a relatively uniform thickness of about 30 meters. In most areas the high Mgo flow is weathered to a dark reddish-brown soil. Scattered weathering spheroids, the remnants of large blocky-jointed parts of the flow, are often the only source for making positive identification as the interiors of these spheroids contain fresh basalt. This flow is generally coarser grained and lighter gray than the low Mgo Grande Ronde flows and it locally exhibits a diktytaxitic or open texture. Cream colored plagioclase glomerocrysts, up to one centimeter in diameter, are common in this flow throughout the area. The distribution density of the glomerocrysts is about 10-15 per square meter. The best example of the high Mgo flow within the area is not in situ. Large boulders, several meters in diameter, which are probably remnants of large columns in the basal portion of the flow are positioned as rip-rap material on a bank behind the Fred Meyers Department Store on Commercial Street at Browning Drive in Salem (Figure 7). Their source was excavation for the building adjacent and to the east of the Fred Meyers store (local information). Many of the boulders have been blasted open and afford excellent fresh-surface exposure. 


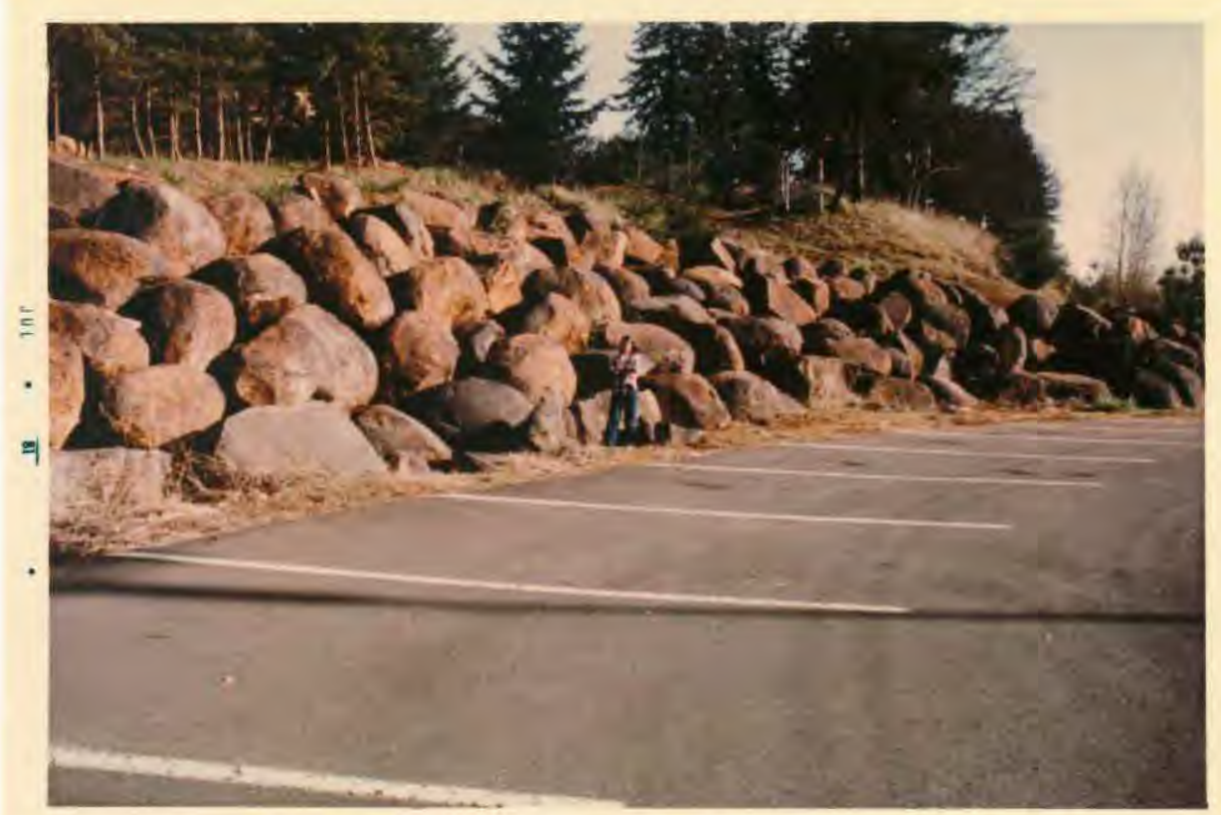

Figure 7. High MgO boulders exposed behind Fred Meyers department store in Salem.

The low MgO - high MgO contact zone is exposed at several localities along Commercial street from about Vista Drive to the 12th Street Cutoff. The baked contact zone on the north side of the Tom-Tom Restaurant parking lot is at the base of the now deeply weathered high Mgo flow. A second exposure occurs behind the laundromat in the Southgate Shopping Center on the northwest corner of Browning Drive and Commercial Street. Here, weathering has penetrated a relatively deep $(5 \mathrm{~m}$ ) vesicular zone (possibly relict scoria) at the top of the winter water flow. Evidence of baking is present at the top of this zone and a few high MgO weathering spheroids occur as float above the baked contact (Figure 8). Fresh, vesicular winter water 
flow crops out farther south, across Commercial Street from the 12th Street Cutoff.

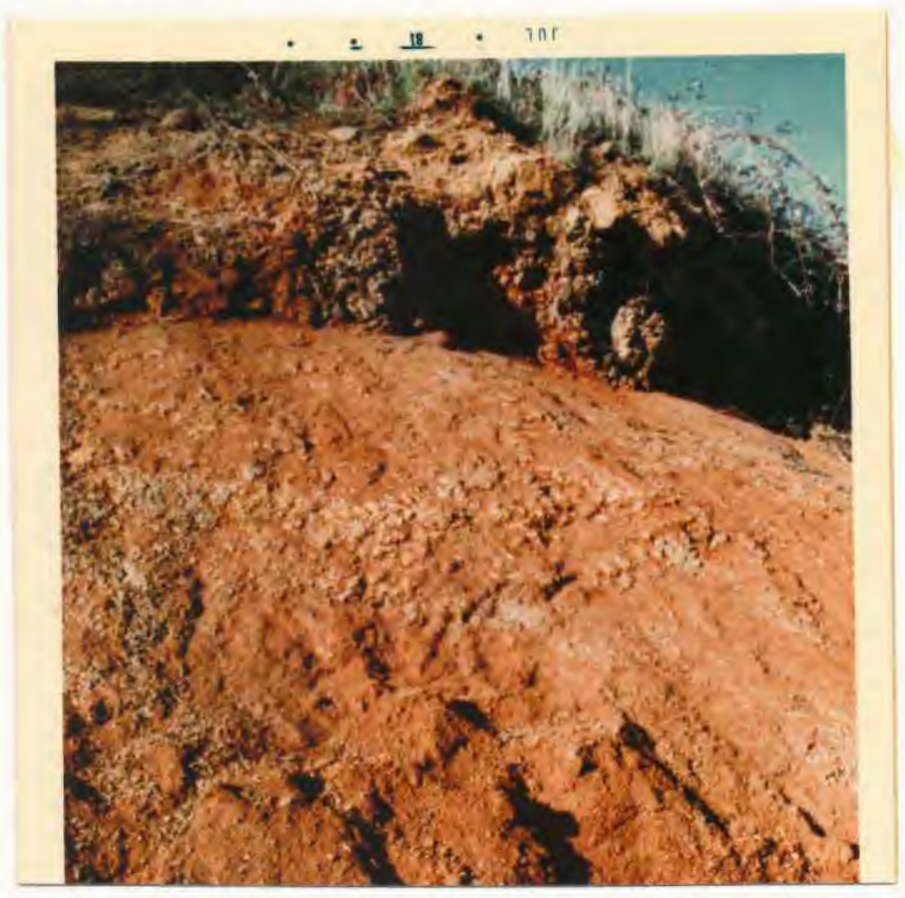

Figure 8. Baked contact zone between Winter Water and high MgO flows behind Southgate Shopping Center in Salem.

\section{Wanapum Basalt}

Two flows of the Frenchman Springs Member of the Wanapum basalt occur in the study area. These flows are distinguished from other basalt types on the basis of chemistry and lithology and from each other by their lithology. Both flows are within the $\mathrm{N}_{2}$ magnetostratigraphic unit (Swanson and others, 1979).

The first Frenchman Springs flow to enter the Salem Hills area was the Ginkgo flow (Mackin, 1961; Bentley and 
others, 1980). Abundant honey colored plagioclase phenocrysts and glomerocrysts, up to several centimeters in length, set in a coarse-grained, dark gray to black matrix make this flow one of the most distinctive of the CRBG. Lateral variation in the concentration of the phenocrysts and glomerocrysts produces local, moderately phyric exposures. Beeson and the author, during preliminary reconnaisance mapping of the CRBG in western Oregon during the summer of 1980, have traced this flow as an intracanyon flow from the Molalla River drainage through the Butte Creek, Abiqua, and Silver Creek (Norman, 1980) drainages and into the southeastern part of the Salem Hills. Locally the flow overfilled its canyon and occurs in section between high MgO Grande Ronde basalt and younger Frenchman Springs basalt flows. The best exposures of this flow are in the southernmost extension of the Salem Hills, near the village of Marion. Several quarries expose the fan jointing and pillow palagonite breccia complexes typical of intracanyon basalt flows of this scale.

The second Frenchman Springs basalt flow is tentatively identified as the informal Kelley Hollow flow (Bentley, 1977) which is believed to be the same as the Maryhill flow of Hammond and others, 1977 (Bentley and others, 1980). This flow is coarse- to very coarse-grained, dark gray, with sparce, irregularly distributed, several centimeter sized plagioclase 
glomerocrysts. The lithology of this flow and the stratigraphic position as seen to the east in the Waldo Hills, i.e. below a younger sparsely phyric Frenchman Springs flow, support the identification as Kelley Hollow. Thickness of the Kelley Hollow flow varies from several meters to 30 meters and averages 10-15 meters. It occurs as a deeply weathered capping on many of the hills in the study area but does not overlie the Ginkgo flow. Much of the Kelley Hollow flow has been removed by erosion. Locally, the Kelley Hollow weathering product is a distinctive dark yellowish orange which contrasts markedly with the reddish brown of the underlying weathered high Mgo unit (Figure 9). Weathering spheroids, usually more angular than those of the Grande Ronde flows, again serve as the only positive identification tool.

The Kelley Hollow-Grande Ronde contact is the most difficult one to map in this area. A several meter thick, finely laminated, micaceous, clay-rich interbed marks the horizon in the east central part of the map area and, along an $I-5$ roadcut where the base of the flow is pillow basalt. The extension of the kelley Hollow to the southwestern margin of the study area is based on chemical data from Prospect Hill auger samples and topographic patterns extrapolated from control areas. 


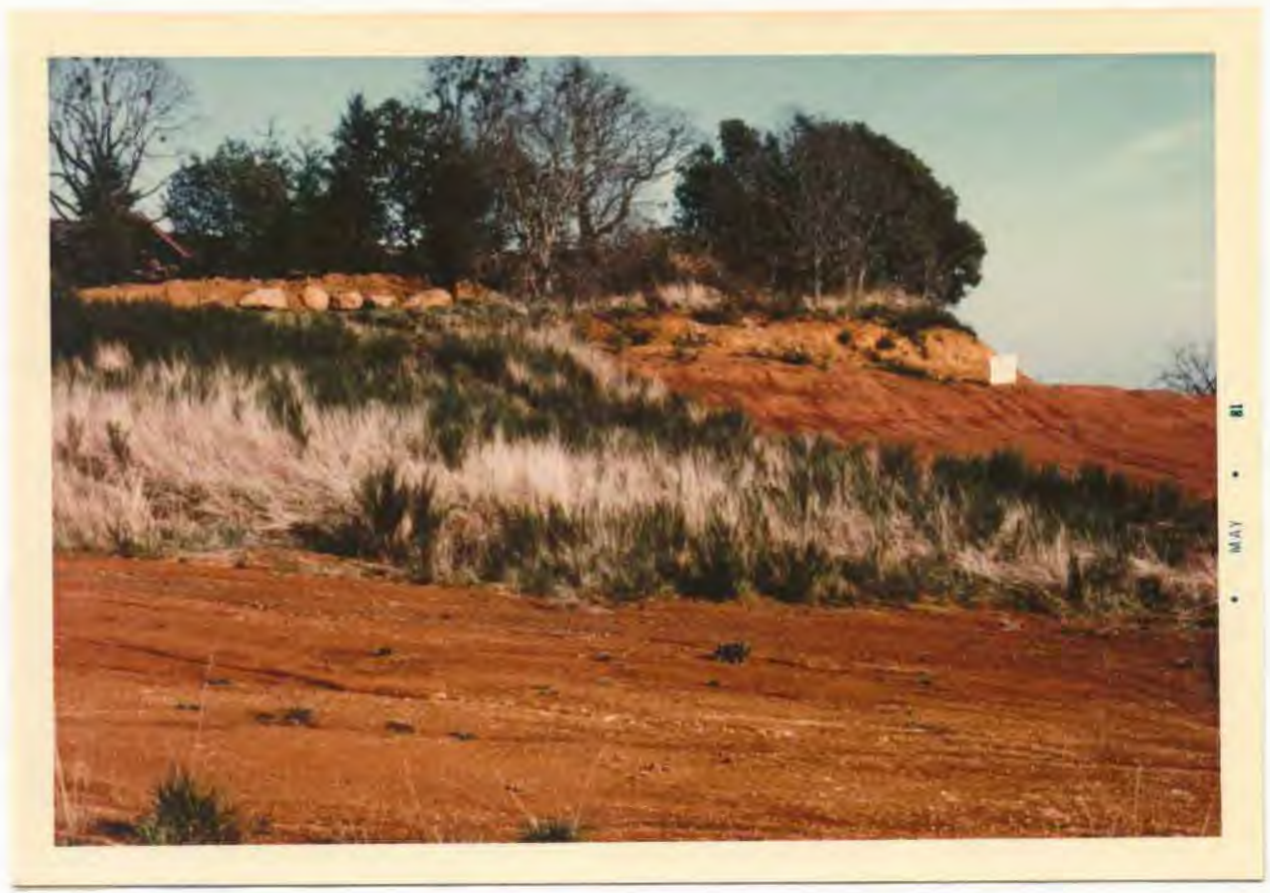

Figure 9. Yellowish-orange weathered Kelley Hollow flow overlying reddish-brown weathered high Mgo flow in housing development at intersection of Mildred Lane and Sunnyside Road in Salem.

\section{BASALT GEOCHEMISTRY}

The U.S.G.S. mapping project provided major element geochemical analyses. Peter R. Hooper of Washington State University determined the concentration values by $\mathrm{x}$-ray fluorescence. The results for the 23 samples analyzed are given in Appendix $\mathrm{A}$ and average concentration values are given in Table $I$. In Figure 10 variations of $\mathrm{SiO}_{2}, \mathrm{P}_{2} \mathrm{O}_{5}$, and total $\mathrm{Fe}$ as $\mathrm{FeO}$ versus $\mathrm{MgO}$ are compared against the low MgO and high MgO Grande Ronde basalt and Frenchman Springs Member values obtained by previous workers. The three chemical types fall into three distinct fields, thus 
COMPARISON OF AVERAGE MAJOR OXIDE CONCENTRATIONS FOR THE LOW MgO, HIGH MgO, AND FRENCHMAN SPRINGS CHEMICAL TYPES IN THE SALEM HILLS TO AVERAGE

CONCENTRATIONS REPORTED IN OTHER WORKS

\begin{tabular}{|c|c|c|c|c|c|c|c|c|c|c|c|c|}
\hline & This $w$ & $k, 198$ & & $\begin{array}{l}\text { Wright } \\
\text { Swanso }\end{array}$ & $\begin{array}{c}\text { Groile } \\
1973\end{array}$ & , and & $\begin{array}{l}\text { Swanson } \\
1979\end{array}$ & and of & ers, & $\begin{array}{l}\text { Bentley } \\
1980\end{array}$ & and ot & rs, \\
\hline & $\begin{array}{l}\text { Iow } \\
\text { Mgo } \\
\end{array}$ & $\begin{array}{l}\text { high } \\
\text { MgO } \\
\end{array}$ & F.S. & $\begin{array}{l}\text { Iow } \\
\text { Mgo } \\
\end{array}$ & $\begin{array}{l}\text { high } \\
\text { MgO } \\
\end{array}$ & F.S. & $\begin{array}{l}\text { low } \\
\text { MgO }\end{array}$ & $\begin{array}{l}\text { high } \\
\text { MgO } \\
\end{array}$ & F.S. & $\begin{array}{l}\text { Iow } \\
\text { MgO }\end{array}$ & $\begin{array}{l}\text { high } \\
\text { MgO } \\
\end{array}$ & F.S. \\
\hline $\mathrm{SiO}_{2}$ & 56.19 & $\overline{53.18}$ & $\overline{51.36}$ & $\overline{55.98}$ & $\overline{54.09}$ & $\overline{51.14}$ & 55.94 & $\overline{53.78}$ & 52.29 & 55.66 & $\overline{53.92}$ & 50.94 \\
\hline $\mathrm{Al}_{2} \mathrm{O}_{3}$ & 15.19 & 14.83 & 14.19 & 13.76 & 14.33 & 13.71 & 14.04 & 14.45 & 13.21 & 14.93 & 15.21 & 14.00 \\
\hline $\mathrm{Fe}_{2} \mathrm{O}_{3}$ & 12.38 & 13.15 & 16.27 & 13.67 & 12.69 & 15.73 & 11.77 & 11.35 & 15.96 & 12.78 & 12.68 & 16.36 \\
\hline MgO & 3.35 & 4.63 & 4.23 & 3.38 & 4.90 & 4.19 & 3.36 & 5.25 & 4.04 & 3.55 & 4.68 & 4.38 \\
\hline $\mathrm{CaO}$ & 6.98 & 8.23 & 7.78 & 7.11 & 8.72 & 8.46 & 6.88 & 7.07 & 7.90 & 7.17 & 8.69 & 8.34 \\
\hline $\mathrm{Na}_{2} \mathrm{O}$ & 2.77 & 2.58 & 2.64 & 3.27 & 2.84 & 2.86 & 3.14 & 2.83 & 2.67 & 2.40 & 2.32 & 2.44 \\
\hline $\mathrm{K}_{2} \mathrm{O}$ & 1.70 & 1.33 & 1.18 & 1.78 & 1.17 & 1.33 & 1.99 & 1.05 & 1.41 & 1.84 & 1.22 & 1.22 \\
\hline $\mathrm{TiO}_{2}$ & 2.15 & 2.01 & 3.05 & 2.20 & 1.78 & 3.00 & 2.27 & 1.78 & 3.17 & 2.06 & 1.83 & 2.97 \\
\hline $\mathrm{P}_{2} \mathrm{O}_{5}$ & 0.34 & 0.32 & 0.51 & 0.39 & 0.31 & 0.56 & 0.43 & 0.28 & 0.71 & 0.33 & 0.30 & 0.52 \\
\hline Mno & 0.25 & 0.22 & 0.22 & 0.21 & 0.20 & 0.24 & 0.19 & 0.19 & 0.22 & 0.20 & 0.21 & 0.25 \\
\hline
\end{tabular}

t total $\mathrm{Fe}$ as $\mathrm{Fe}_{2} \mathrm{O}_{3}$ 
indicating the value of chemical variation as a CRBG identification tool (Wright, Groiler, and Swanson, 1973). Relatively wide scatter for some of the literature values is quite likely due to the different number of flows and different particular flows being sampled.

Minor and trace element geochemistry was determined for 13 basalt samples by the author via Instrumental Neutron Activation Analysis (INAA) at Portland State University. The INAA technique, results and possible errors are discussed in Appendix B. Figure 11 is a plot of INAA determinations of several key elements. Varying degrees of overlap in the values for two or three of the chemical types is apparent for all elements except Thorium, where the three types do not overlap. In the $\mathrm{Fe}, \mathrm{La}, \mathrm{Cr}$, and Ce plots, however, one of the types segregated from the other two. Thus a variety of Cartesian plots, each of which would separate the three basalt types into three distinct fields as the Mgo plots of Figure 10 did, could be constructed for this data.

Even though the relative average concentration values of the various elements determined in this study by INAA are consistent with those of other studies (see Table II), absolute values do vary considerably. Such variations certainly inhibit the establishment of any quantitative 

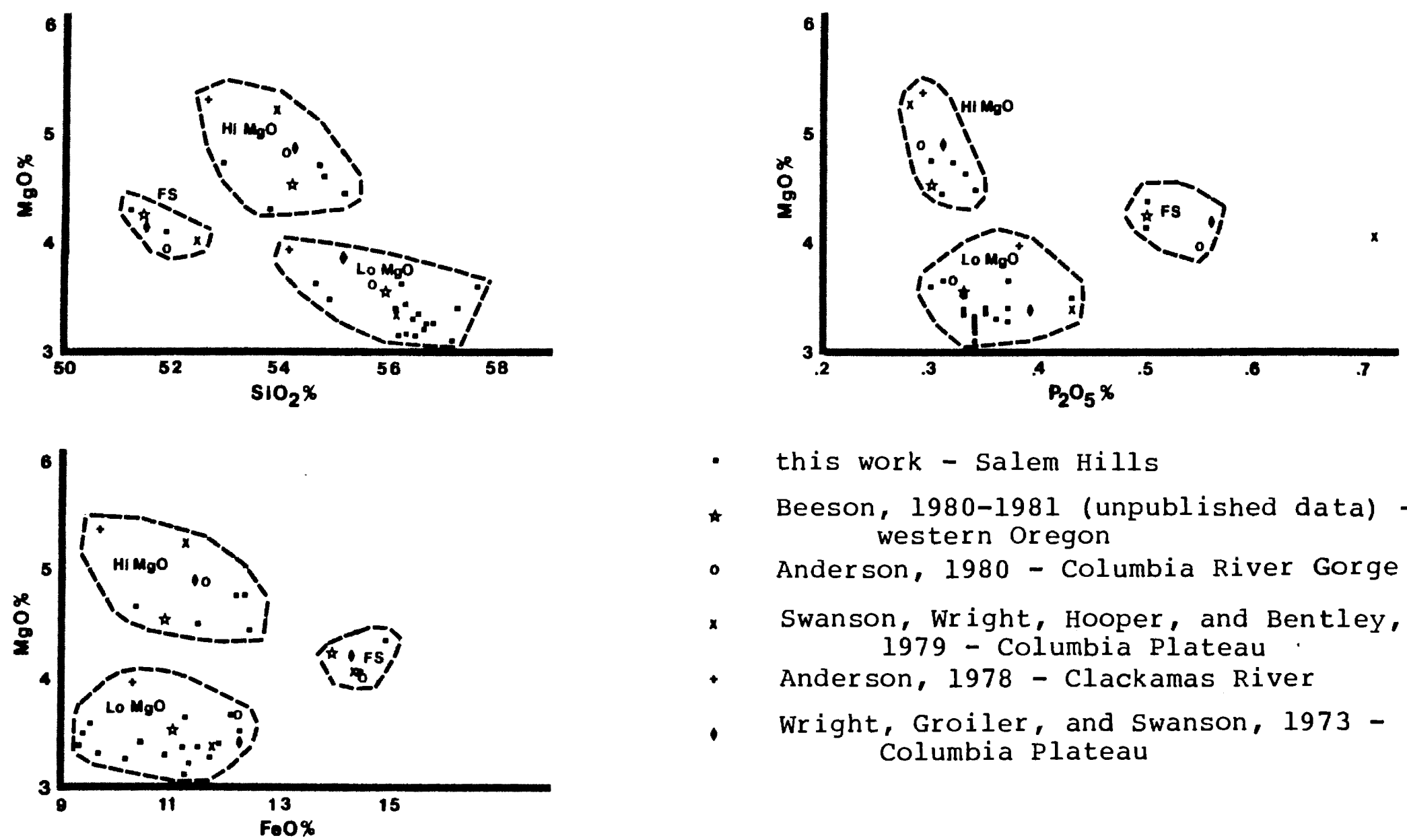

- this work - Salem Hills

* Beeson, 1980-1981 (unpublished data) western Oregon

- Anderson, 1980 - Columbia River Gorge

x Swanson, Wright, Hooper, and Bentley, 1979 - Columbia Plateau

- Anderson, 1978 - Clackamas River

- Wright, Groiler, and Swanson, 1973 Columbia Plateau

Figure 10. MgO variation diagrams for Salem Hills CRBG flows compared to average values determined by other workers for the low Mgo, high Mgo, and Frenchman Springs chemical types 


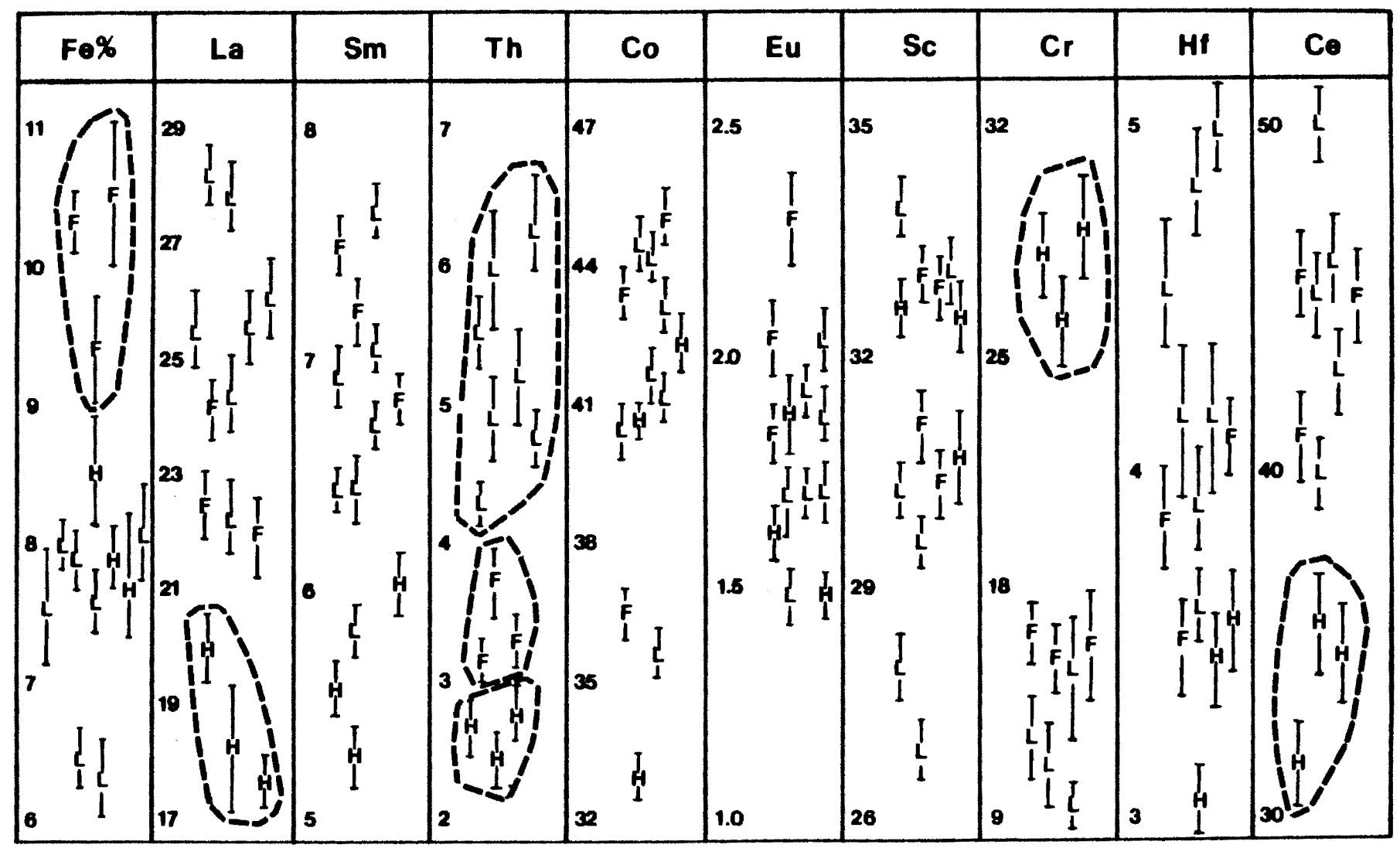

$\mathbf{H}=$ high Mgo chemical type

$\mathbf{L}=$ low MgO chemical type

$\boldsymbol{F}=$ Frenchman Springs chemical type

Figure 11. INAA determined concentrations of selected elements for samples of the three basalt chemical types found in the Salem Hills. 
COMPARISON OF AVERAGE INAA DETERMINED Fe AND SELECTED TRACE ELEMENT CONCENTRATIONS FOR THE LOW MgO, HIGH MgO, AND FRENCHMAN SPRINGS CHEMICAL TYPES IN THE SALEM HILLS TO AVERAGE CONCENTRATIONS REPORTED IN OTHER WORKS

\begin{tabular}{|c|c|c|c|c|c|c|c|c|c|}
\hline & \multicolumn{2}{|c|}{$\begin{array}{l}\text { This Work } \\
\text { Salem Hills }\end{array}$} & \multirow[b]{2}{*}{$\begin{array}{l}\text { Frenchman } \\
\text { Springs } \\
\end{array}$} & \multicolumn{3}{|c|}{$\begin{array}{l}\text { Swanson and Wright (1981) } \\
\text { Columbia Plateau }\end{array}$} & \multicolumn{3}{|c|}{$\begin{array}{l}\text { Nathan and Frutchter (1974) } \\
\text { Tygh Ridge }\end{array}$} \\
\hline & $\begin{array}{l}\text { low } \\
\text { MgO }\end{array}$ & $\begin{array}{l}\text { high } \\
\text { MgO }\end{array}$ & & $\begin{array}{l}\text { low } \\
\text { MgO }\end{array}$ & $\begin{array}{l}\text { high } \\
\text { MgO } \\
\end{array}$ & $\begin{array}{l}\text { Frenchman } \\
\text { Springs } \\
\end{array}$ & $\begin{array}{l}\text { low } \\
\text { MgO } \\
\end{array}$ & $\begin{array}{l}\text { high } \\
\text { MgO } \\
\end{array}$ & $\begin{array}{l}\text { Frenchman } \\
\text { Springs } \\
\end{array}$ \\
\hline $\mathrm{Fe}$ & 7.46 & 8.07 & 10.07 & 9.15 & 8.82 & 11.18 & NR & NR & NR \\
\hline $\mathrm{La}$ & 25.60 & 18.80 & 23.10 & 28.70 & 18.20 & 26.50 & 24 & 19 & 24 \\
\hline $\mathrm{Sm}$ & 6.70 & 5.62 & 7.06 & 7.70 & 5.40 & 7.20 & 6.9 & 5.3 & 7.4 \\
\hline Sc & 30.10 & 31.90 & 32.20 & 31.20 & 37.04 & 36.39 & 31 & 33 & 34 \\
\hline Th & 5.28 & 2.68 & 3.38 & 6.10 & 3.50 & 3.70 & 5.8 & 3.5 & 3.7 \\
\hline Co & 41.00 & 38.50 & 41.80 & 36.90 & 41.30 & 39.40 & 34 & 38 & 39 \\
\hline $\mathrm{Eu}$ & 1.76 & 1.69 & 1.94 & 2.18 & 1.68 & 2.27 & NR & NR & NR \\
\hline $\mathrm{Cr}$ & 11.10 & 27.60 & 15.30 & 11.70 & 100.10 & 33.10 & 15 & 36 & 30 \\
\hline Hf & 4.28 & 3.24 & 3.84 & 5.20 & 3.70 & 4.35 & NR & NR & NR \\
\hline $\mathrm{Ce}$ & 44.40 & 32.80 & 43.90 & 58.00 & 38.00 & 52.50 & NR & NR & NR \\
\hline
\end{tabular}

NR not reported

values in PPM except $\mathrm{Fe}$ which is in 8 
criteria for identifying CRBG chemical types on the basis of INAA results. MY experience with several INAA runs has been that intra-experimental consistency is quite good but that inter-experimental consistency is not always good (Appendix B).

Another problem that must be dealt with in studies of basalt geochemistry is flow inhomogeneity. Chemical variation within a single, 11 meter thick Icelandic tholeiite flow has been studied by Watkins and others (1970) and Lindstrom and Haskin (1981). Major and trace element variations through vertical sections of the flow were found to substantially exceed those expected from analytical uncertainties and to be random with respect to position within the flow. Mathematical modeling by Lindstrom and Haskin indicates that intraflow trace element inhomogeneity was as great as interflow compositional differences in their study.

\section{DISCUSSION}

Observations related to the distribution and geometry of the respective Columbia River Basalt Group flows suggest that topography and the development of structural relief before and during basalt deposition were the main controlling factors of basalt distribution. Several of the flows found in the Salem Hills and in areas to the east reflect a 
pattern whereby a given flow would fill or partially fill the existing topographic lows, as evidenced by overthickened portions of the flow, and cause the subsequent flow to follow a different route, usually in a newly developed low area. This pattern appears to be most strongly developed in the post Grande Ronde flows (which happen to be the best exposed flows, allowing relatively good estimates of thickness variations throughout their distribution). Figure 12 shows the general inferred distribution of the informal basalt units in and adjacent to the study area.

Most flows have apparently followed a southwesterly course into the Salem area from a gap in the ancestral Cascades through which they entered western Oregon (Beeson and Moran, 1979). Goodwin (1973), after Snavely and Wagner (1963), projected a major drainage along this same orientation as the conduit for the volcaniclastic contribution to the Yaquina Formation, a late oligocene deltaic sequence located about $75 \mathrm{kilometers} \mathrm{to} \mathrm{the} \mathrm{southwest} \mathrm{of} \mathrm{Salem.}$

The oldest flows of the Salem area are not well enough exposed to provide any clue to the possible existance of a major drainage at the time they flowed westward from the Columbia Plateau. The $R_{2}$ flow is very sparsely exposed in several areas both east and north of the Salem Hills but not to a thickness that might indicate 


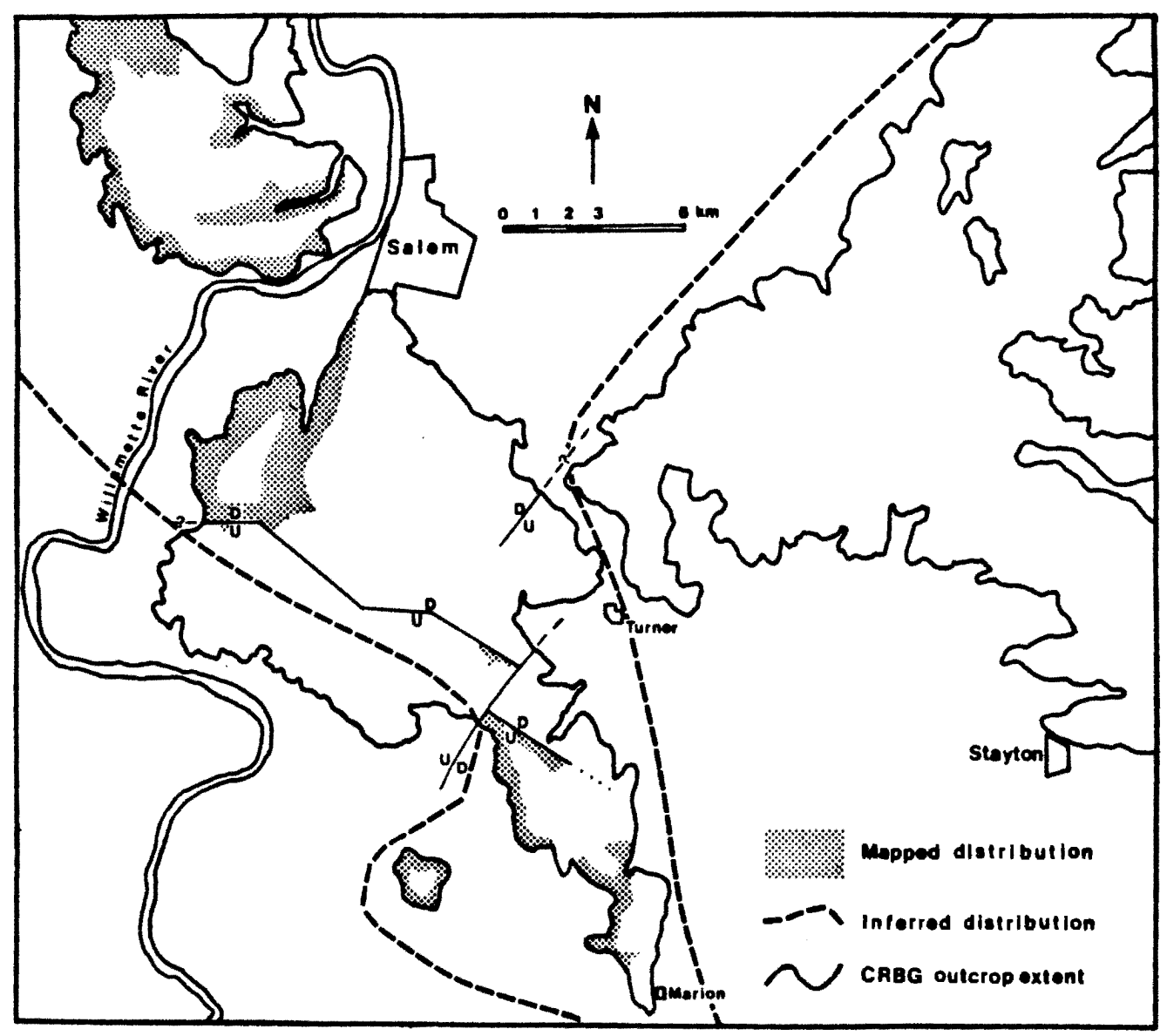

Figure 12a. Distribution of unnamed low $\mathrm{MgO} \mathrm{N}_{2}$ flow 


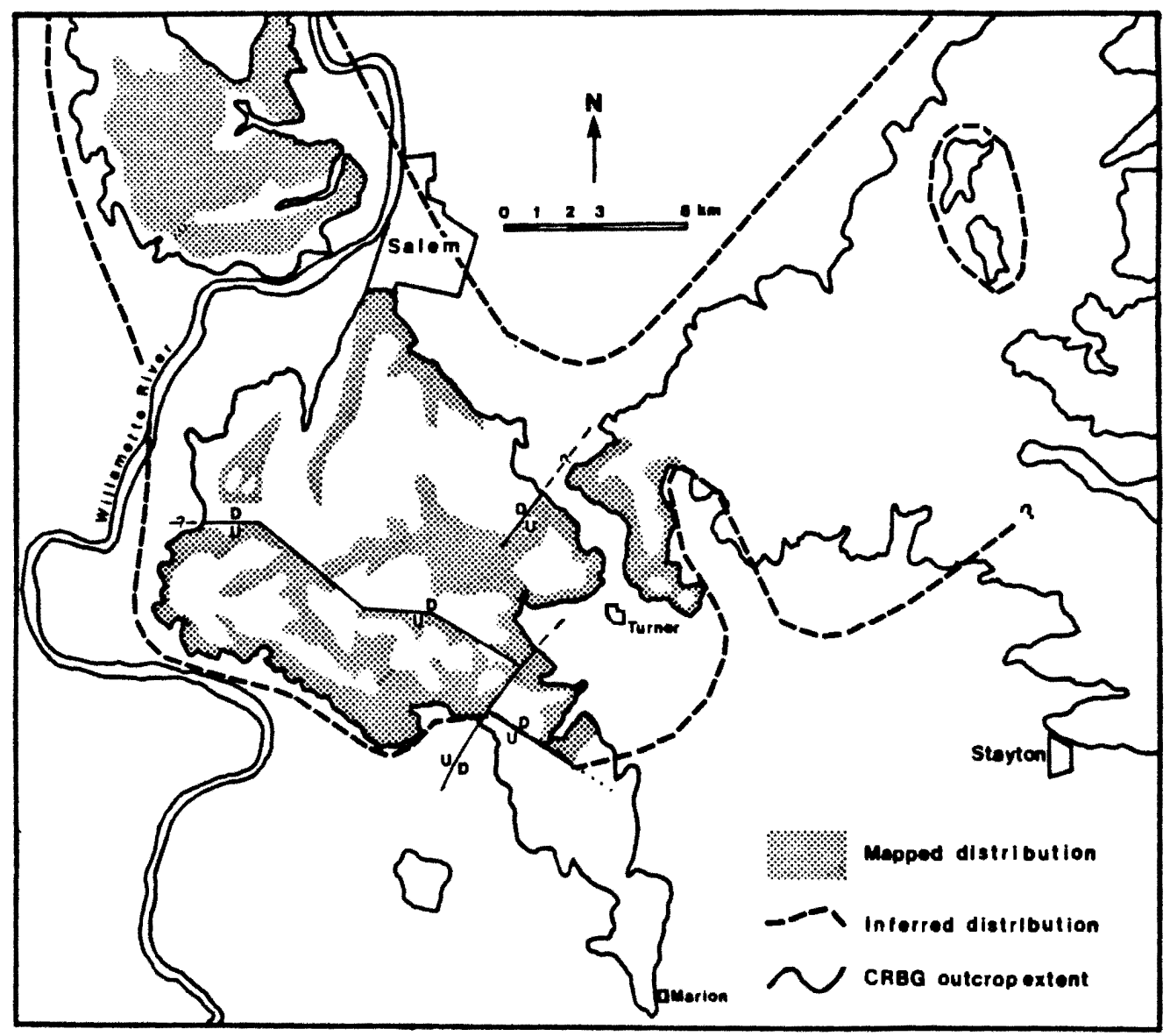

Figure 12b. Distribution of the winter water flow 


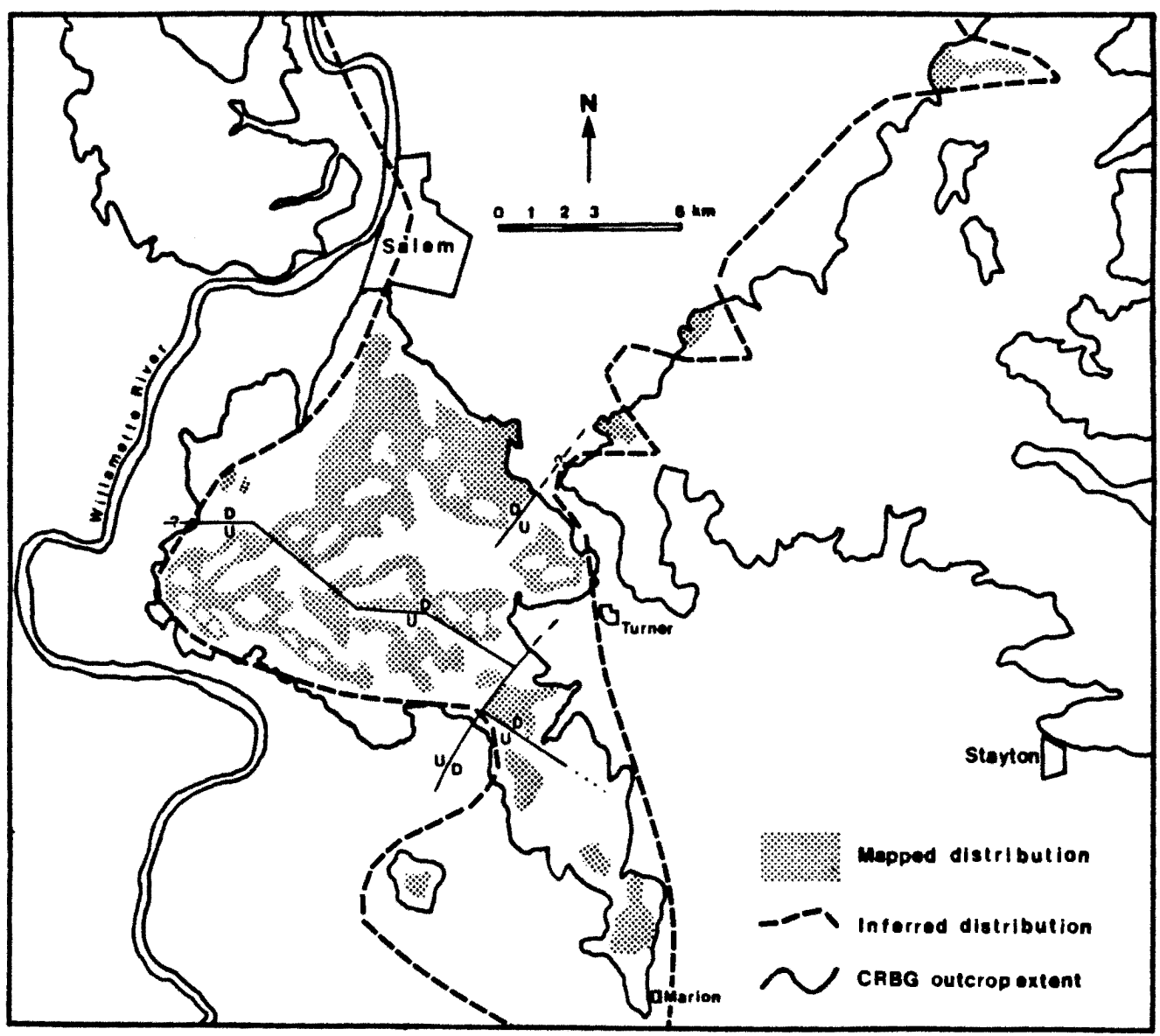

Figure 12c. Distribution of the high MgO flow 


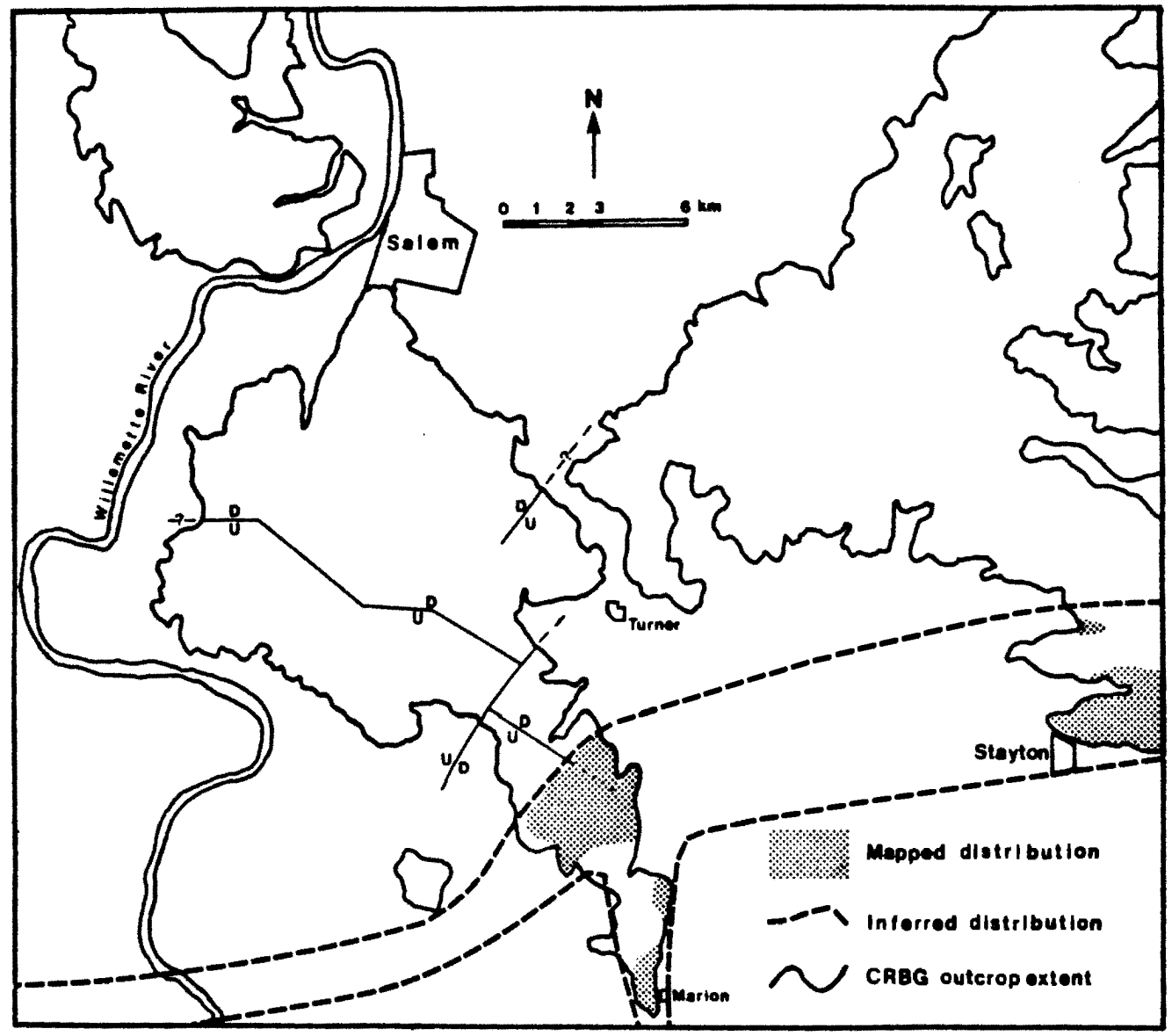

Figure 12d. Distribution of the Ginkgo flow 


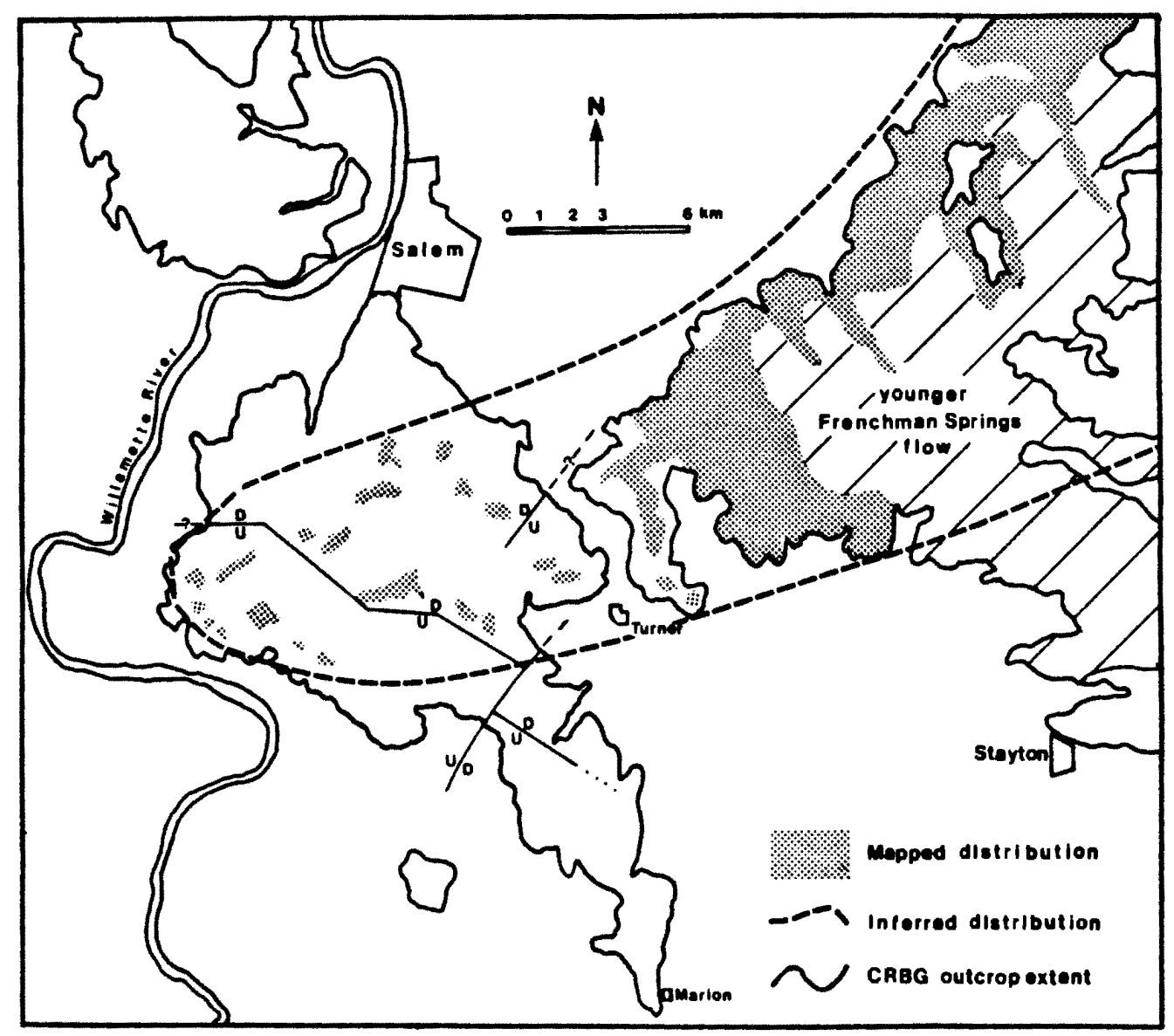

Figure 12e. Distribution of the Kelley Hollow flow 
it was filling a substantial drainage. The lowest $\mathrm{N}_{2}$ flow (Figure 12a) does thicken considerably to the north both within the study area and into the Eola Hills; but this seems to be due more to a topographic high to the south at the time of deposition rather than to an erosional low to the north.

The next flow to enter the Salem area was the winter Water flow (Figure 12b). It occurs over a wide area as a fairly uniform sheet, thus indicating little topographic relief to the area at the time of its deposition - except for the high area in the south against which it thins and laps out. The reason for the Winter Water flow's absence in the Parrish Gap area is unclear but may be related to some relative uplift due to faulting prior to its deposition

The high Mgo flow (Figure 12c), like the winter water flow, is also a relatively uniform thickness throughout the area. A noticeable exception is in the Waldo Hills where the high MgO flow is missing from the section in most places Either the area was a high around which the high Mgo flowed or the high Mgo flow was deposited and then eroded away before deposition of younger flows on the winter water flow. Evidences are present to support both hypotheses. 
Following the high Mgo deposition a hiatus to basalt deposition in western oregon took place. During this time a major canyon was eroded, primarily along the southern margin of earlier deposited basalt flows, from (at least) the present Molalla River drainage to the Salem Hills. The contact between the hard basalt and relatively soft sedimentary strata apparently controlled the location of this drainage. An exception is seen within the present Silver Creek drainage where the canyon was cut entirely within older basalt flows (Norman, 1980). A sedimentary inlier to the Columbia River Basalt Group is in close proximity to this shift but the relationship between the drainage shift and the inlier is not known. In the salem Hills, the canyon is again near the margin of the earlier basalt flows.

This canyon became a channel for the voluminous Ginkgo flow (Figure 12d) which, probably due to hydraulic damming, completely overfilled the canyon in some areas. The southern extension of the Salem Hills past Marion and toward Jefferson consists mainly of this flow, but here the flow did not fill the main canyon, but a 75 meter deep tributary to the primary drainage. The lava flowed for at least 5 kilometers southward in this valley, developing a thick zone of interbedded palagonite and lava. The general trend of the main drainage at its westernmost exposure 
is slightly south of west, toward Cape Foulweather on the Oregon coast.

The Ginkgo flow obviously produced major disruption in local drainage patterns. There is no evidence from succeeding flows to indicate re-establishment of another significant valley in the area before their deposition. In fact, pillowing and a fairly uniform thickness of the Kelley Hollow flow along with the presence of a finely laminated interbed below the flow are good evidences for ponding of water and, hence, poorly developed drainage at the time of its deposition. The Kelley Hollow flow follows a parallel course to the Ginkgo along its northern margin (Figure 12e). A significant aspect of the Kelley Hollow's geometry within the study area is the general thickening to the northeast which suggests an angular unconformity between the Kelley Hollow and high MgO flows. This would indicate that folding of the homocline may have started prior to deposition of the Kelley Hollow flow and have some important implications to the main ferruginous bauxite models.

Thus, detailed stratigraphy of the Columbia River Basalt Group can reveal the complicated interplay of topography and basalt deposition and lead to conclusions regarding the development of tectonic structures and 
erosional patterns. The relationship between the major Cascade drainage of Goodwin (1973) and the Ginkgo intracanyon drainage is a significant question that warrants consideration. Chemcial analysis of the basalt constituent of the Yaquina Formation would help establish whether the two drainages could be related. If a Columbia River Basalt Group component is present then some rethinking of ages would be in order for the Yaquina delta. If a Columbia River Basalt Group component is not present then the mouth of the Ginkgo Canyon is yet to be found. 


\section{RELATIONSHIP OF FERRUGINOUS BAUXITE TO BASALT}

Corcoran and Libbey (1956) produced a map showing the distribution of lateritic horizons, nearly all of which contain ferruginous bauxite, within the Salem Hills. Their data is superimposed on the data of Plate 1 in Plate 2 of this report. Their distribution data were based on field reconnaissance and data obtained from 25 hand augered holes to an average depth of 6.5 meters. Average thickness of the ferruginous bauxite deposits is 4.4 meters and they were observed to thicken slightly to the northeast. The thickest ferruginous bauxite section, over 13 meters, is located in the SW $\frac{1}{4}$ sec. 26, T.8 S., R. 3 W. (Hook, oral communication). Most of the deposits are centrally located within the salem Hills with the largest concentration being an area compassing sections $21,22,27$, and 28, T.8 S., R. 3 W.

A comparison of the ferruginous bauxite distribution to the distribution of the various CRBG flows demonstrates a very strong association between ferruginous bauxite occurrence and the distribution of the kelley Hollow flow. In several areas there is not a coincidence between ferruginous bauxite and the Kelley Hollow flow. This may be explained in a number of ways. First, as in the case of sections 19 and 29, just east of Prospect Hill, 
the Kelley Hollow high MgO contact simply was not inferred downslope. Control on the location of the contact in this area is poor. The three patches of ferruginous bauxite located in sections 28,34 , and 35, T.8 S., R.3 W. are apparently not associated with the Kelley Hollow flow at all. According to Hook (oral communication) however, these deposits are not more than a less than 1 meter thick crust of gibbsite nodules. These are believed to be remnants after the erosion of thicker ore zones which may well have formed within the Kelley Hollow flow. After faulting, the Kelley Hollow flow and the ferruginous bauxite may have been stripped from this trend by erosion. The hilltops in the eastern side of the main section of the Salem Hills, in sections 24 and 25, T. 8 S., R. 3 W., and sections 29 and 30, T.8 S., R.2 W. are surprising in that they are capped by a relatively thick section of Kelley Hollow flow yet are not reported to contain ferruginous bauxite. These hills may have been overlooked by Corcoran and Libbey (1956) as no augering is reported for them.

In addition to the association suggested by planimetric distributions, the thicknesses of the two units vary sympathetically. The general thickening trend of the laterites to the northeast parallels a similar trend for the Kelley Hollow flow. In fact, the thickest section of ferruginous bauxite in the Salem Hills occurs within one 
of the thickest sections of the Kelley Hollow flow. Despite the uncertainties involved in Corcoran and Libbey's well data extrapolation and in my location of geologic contacts in weathered materials, the spacial association observed for the ferruginous bauxite and the Kelley Hollow flow is interpreted to reflect a real stratigraphic correlation between the distribution of the ferruginous bauxite deposits and the Kelley Hollow flow.

An important implication of this interpretation regards the temporal aspect of lateritization. All previous workers have agreed that laterization post-dates basalt deposition. The correlation of the laterites to a particular basalt flow allows establishment of a maximum absolute age for the onset of laterization to form ferruginous bauxites. This age is approximately 15 million years B.P., the age of the Frenchman Springs Member of the Wanapum Basalt (Swanson and others, 1979). However, the development of a soil zone between the low MgO and high Mgo chemical types, as evidenced by a baked contact along Commercial street, suggests that weathering was an active process in this area prior to the deposition of the Kelley Hollow. The question of how long laterization continued or if it is still active cannot be answered for this area with the available data. 


\section{LATERITE AND FERRUGINOUS BAUXITE STRATIGRAPHY}

\section{GENERAL}

Penetration of ferruginous bauxite ore horizons by drilled and augered holes in this study was moderately successful. The Reese Hill profile contained approximately 7.5 meters of ferruginous bauxite ore, the greatest thickness sampled. The Prospect Hill and Turner Freeway profiles include about 2 meters and 1 meter of ferruginous bauxite ore, respectively.

The term "ore" is used informally in this study as has been done in previous reports, but is defined as ferruginous bauxite with less than $15 \%$ silica and greater than $28 \%$ alumina. This definition is in contrast to the less than $10 \%$ silica and greater than $30 \%$ alumina cut-offs used by previous workers and is necessitated by apparent discrepancies in analytical results, particularly for silica, between this study and previous studies. The nature of and possible explanations for these analytical differences are discussed in Appendix C. Each group of analyses is thus treated as being internally consistent and, although "ore" is subject to different definition, the thickness of ore horizons in the Reese Hill hole and the nearby holes number 23 and 27 of Corcoran and Libbey (1956) are similar (Figure 13). 


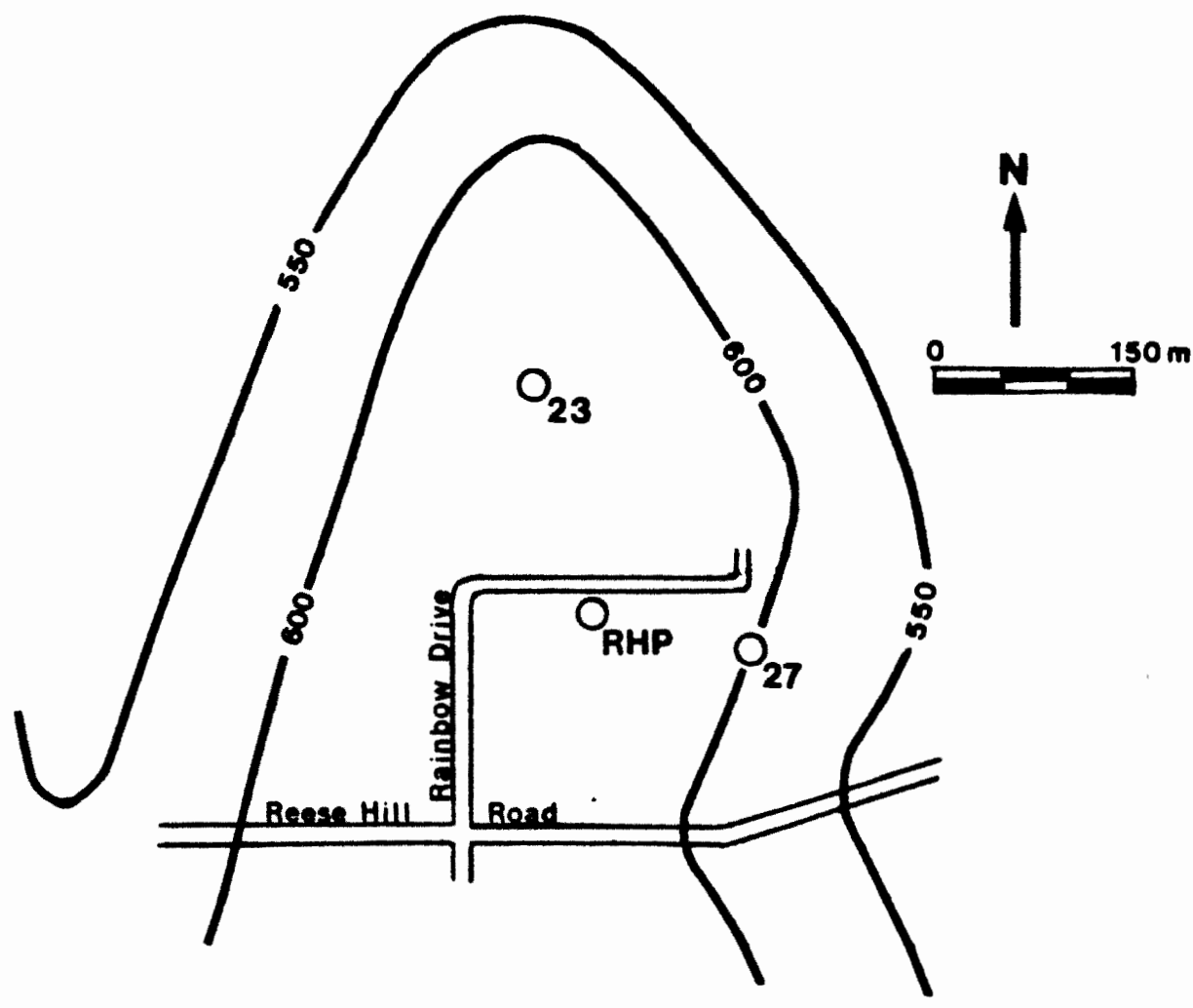

Overburden

$$
\begin{aligned}
& \text { Hole \#23 } \\
& \text { Hole \#27 } \\
& \text { Reese Hill } \\
& \text { Profile (RHP) }
\end{aligned}
$$

$0.6 \mathrm{~m}$

$5.0 \mathrm{~m}$
Ore

$8.5 \mathrm{~m}$

$5.5 \mathrm{~m}$

$7.5 \mathrm{~m}$
Depth

$$
9.6 \mathrm{~m}
$$

$6.1 \mathrm{~m}$

$13.5 \mathrm{~m}$

Figure 13. Comparison of ore thicknesses in two holes of Corcoran and Libbey (1956) and the Reese Hill profile hole of this study 
The stratigraphy of the Salem Hills ferruginous bauxite deposits is somewhat different from Hook's generalized ferruginous bauxite stratigraphy (Figure 14). The silty clay overburden and pisolitic zones are not found in the upper portions of ferruginous bauxite sections in the Salem Hills. In some areas, particularly along the northwest-southeast trending ridge of sections 28, 34, and 35, T.8 S., R.3 W. which includes Jackson Hill, matrix material from the nodular zone and much or all of the fine-grained zone has been removed by erosion. The result is a relatively high concentration of gibbsite nodules occurring within a high silica matrix in the upper soil zone. These nodules are particularly evident in plowed fields over such horizons.

\section{TURNER FREEWAY PROFILE}

The Turner Freeway profile (Figure 15) was developed from auger and outcrop samples. Excavation for a church building located on this hill unearthed numerous blocky, angular, up to boulder size gibbsite nodules from the upper 1 - 2 meters of deep reddish-brown soil. A sample (PHN 1) of these nodules contained $41.88 \mathrm{Al}_{2} \mathrm{O}_{3}$ and $1.18 \mathrm{Fe}_{2} \mathrm{O}_{3} ; \mathrm{SiO}_{2}$ was not determined. The reddish-brown matrix material, however, contained $27.28 \mathrm{Al}_{2} \mathrm{O}_{3}, 17.98 \mathrm{Fe}_{2} \mathrm{O}_{3}$, and $32.28 \mathrm{SiO}_{2}$ (sample TFB 3-8) and x-ray diffraction patterns did not contain peaks for gibbsite. Kaolinite was the chief clay 


\begin{tabular}{|c|c|c|c|c|c|}
\hline \multicolumn{2}{|c|}{ Thickness } & Zone & Composition & Profile & Description \\
\hline renges & Avereopo & & \multirow{3}{*}{ 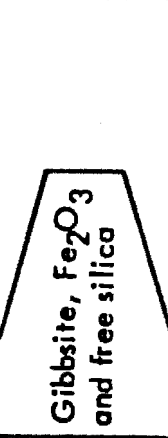 } & \multirow{3}{*}{ 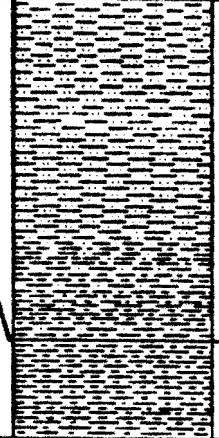 } & \multirow{3}{*}{$\begin{array}{l}\text { Tan silt, loose, soft; grades to red } \\
\text { silty clay, dense, plastic, with thin } \\
\text { silt beds }\end{array}$} \\
\hline & 6 & $\begin{array}{l}\text { Silty Clay } \\
\text { Overburden }\end{array}$ & & & \\
\hline & 1 & $\begin{array}{l}\text { Pisolitic } \\
\text { Zone }\end{array}$ & & & \\
\hline & 4 & $\begin{array}{l}\text { Nodular } \\
\text { Zone } \\
\text { Fine-grained } \\
\text { Zone }\end{array}$ & 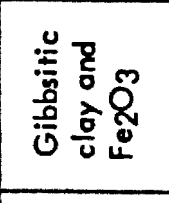 & 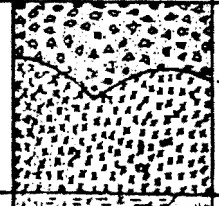 & $\begin{array}{l}\text { Hard gibbsitic and limonitic nodules } \\
\text { or fragments, subrounded to angular } \\
\text { Fine-grained, brown, ferruginous } \\
\text { bauxite with magnetite and ilmenite } \\
\text { crystals }\end{array}$ \\
\hline \multirow{3}{*}{ 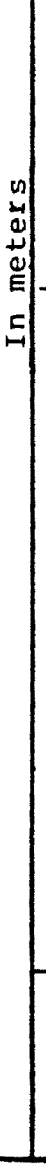 } & 6 & $\begin{array}{l}\text { Upper Relic } \\
\text { Basalt Zone }\end{array}$ & 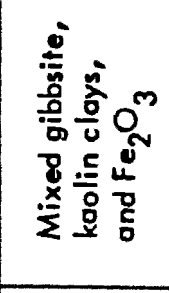 & 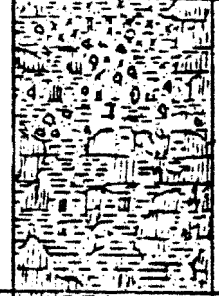 & $\begin{array}{l}\text { Varicolored, soft clay with relic basalt } \\
\text { texture. Some spheroidal weathering } \\
\text { with occasional hard basalt boulders at } \\
\text { center of spheroids. Mangonese oxides } \\
\text { increase toward bottom. }\end{array}$ \\
\hline & \multirow[t]{2}{*}{ ? } & $\begin{array}{l}\text { Lower Relic } \\
\text { Basalt Zone }\end{array}$ & 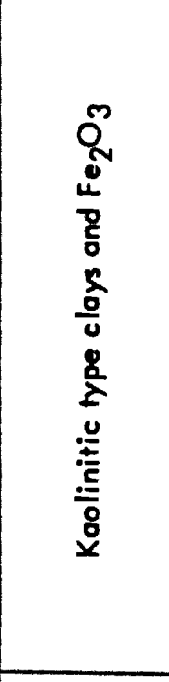 & 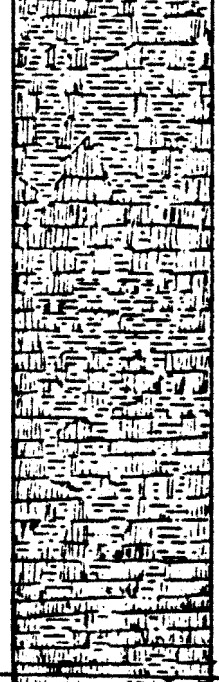 & $\begin{array}{l}\text { Clay-altered basalt, dark-gray to } \\
\text { brownish with orange to pink halloysite } \\
\text { and black manganese oxides in joints. } \\
\text { This zone is generally a firm saprolite } \\
\text { but may have hard, unaltered basalt } \\
\text { boulders. }\end{array}$ \\
\hline & & Basolt & & 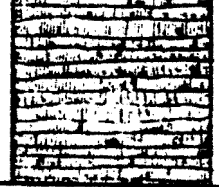 & Hard, black basalt \\
\hline
\end{tabular}

Figure 14. Generalized ferruginous bauxite stratigraphy (after Figure 2 of Hook, 1976) 


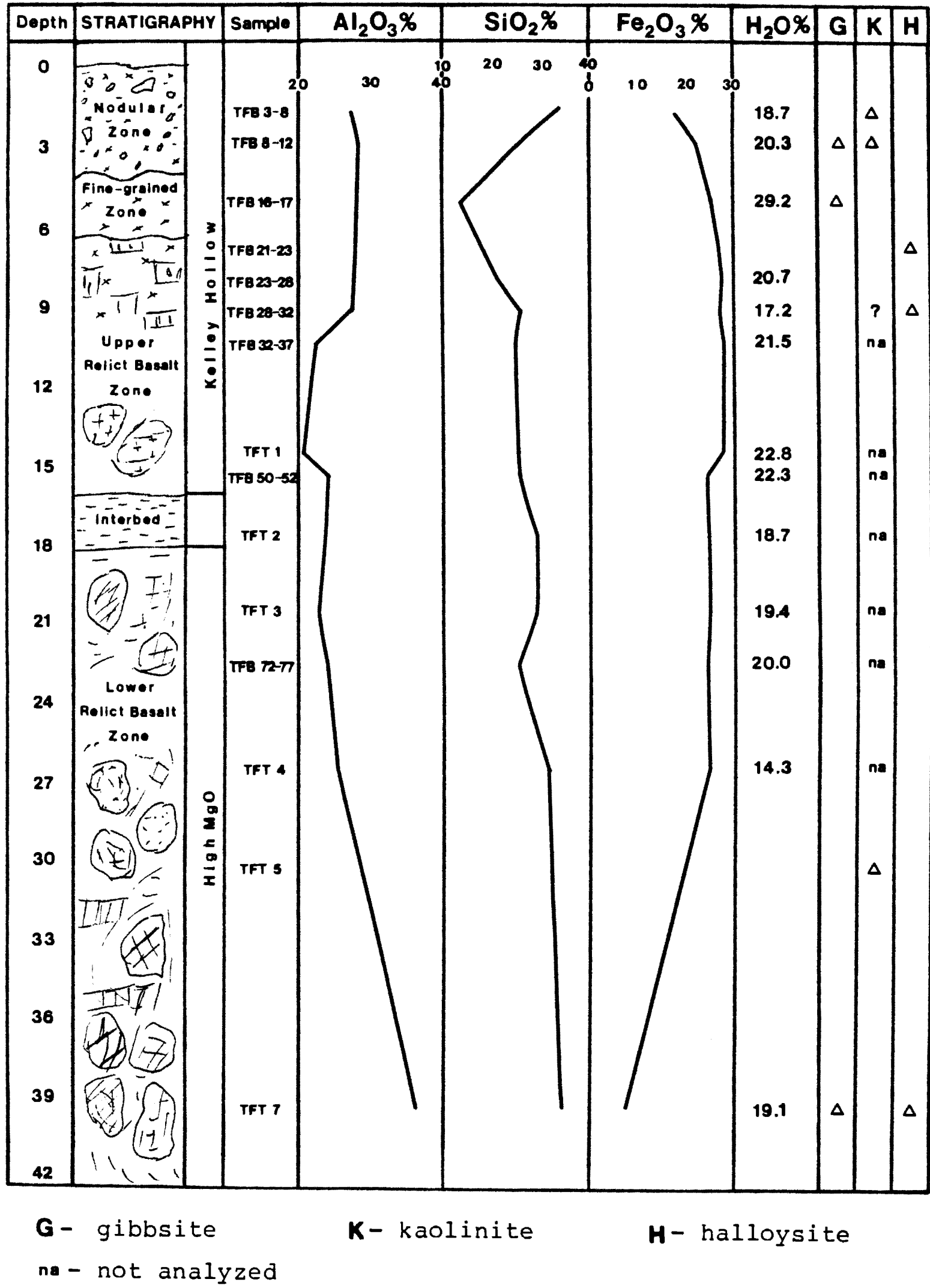

Figure 15. Turner Freeway laterite profile 
mineral. This zone is of interest because of its distinctive appearance in the fresh road cut formed during widening construction of I-5 in mid-summer of 1981. As the photographs of Figure 16 show, this zone thins along the top of the hill and thickens down slope to the north, "draping" in a manner similar to what has been reported for ferruginous bauxite horizons by nearly all previous investigators of Pacific Northwest deposits. This zone was about 4 meters thick at the top of the auger hole. Silica content decreased below the reddish zone and gibbsite is indicated by $x$-ray patterns. At 4.8 meters of depth and continuing for 2.4 meters the lithology is a moist, orangish clay which was determined to be predominately gibbsite. Analysis of a sample (TFB 16-17) from the top of this zone indicated ferruginous bauxite ore with concentrations of $\mathrm{SiO}_{2}, \mathrm{Al}_{2} \mathrm{O}_{3}$, and $\mathrm{Fe}_{2} \mathrm{O}_{3}$ as 13.6\%, 28.2\%, and 28.3\%, respectively. This zone is the fine-grained zone of the Hook profile and the overlying zone is like his nodular zone except for its high silica content. A drive core taken immediately below the ferruginous bauxite, in a moist, highsilica zone containing halloysite as the main clay mineral, displayed relict basalt texture despite the high degree of weathering. This sample represents the uppermost relict basalt zone. Very fine-grained magnetite and possibly ilmenite are abundantly distributed throughout these upper portions of the profile. 

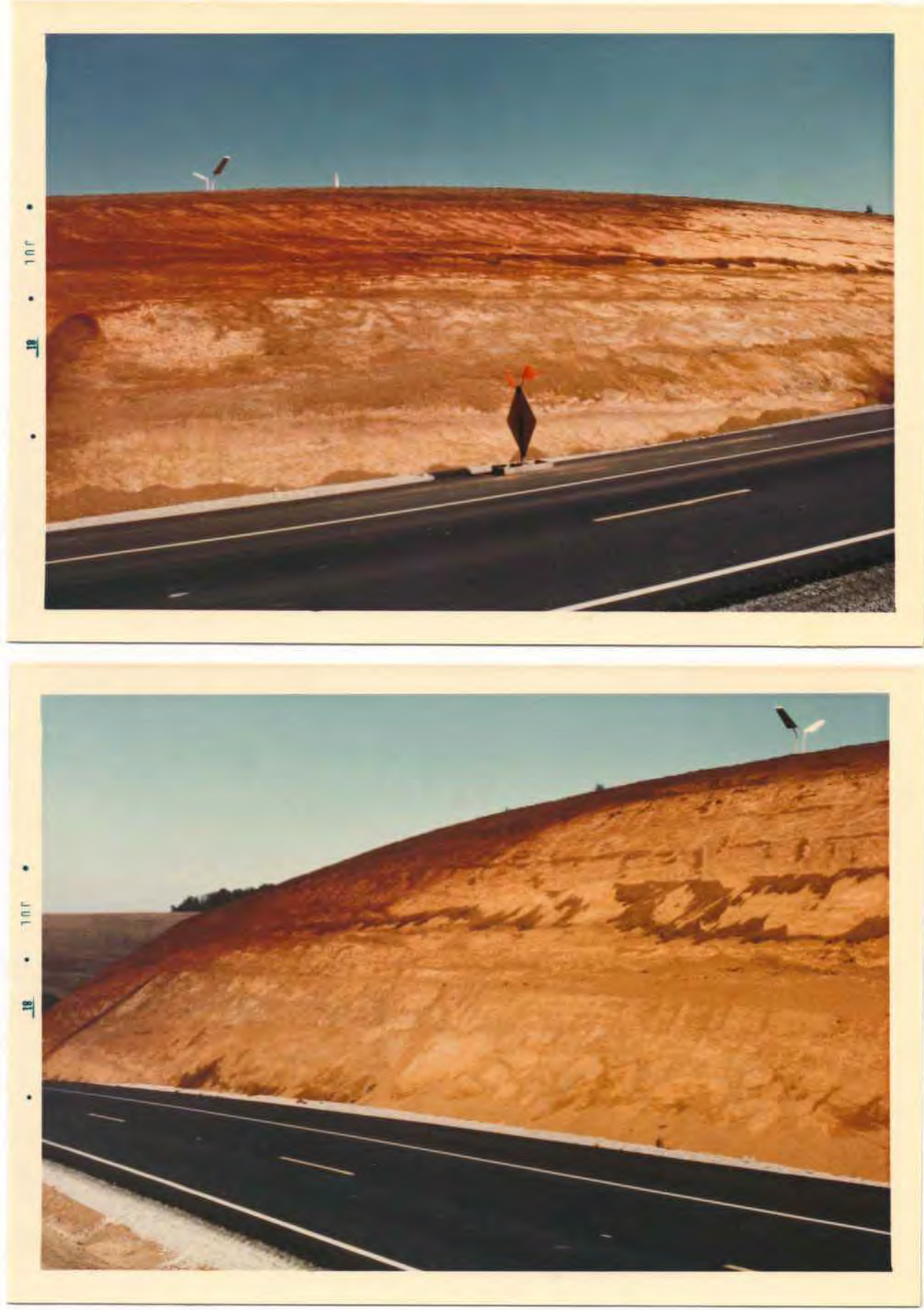

Figure 16. "Draping" of Reddish-brown Horizon in a Roadcut on the east side of I-5 just South of the Sunnyside Interchange; top view is looking southward, and bottom view is looking northward. 
Except for variable moisture content, auger cuttings reflect a relatively consistent relict basalt zone for approximately 9 meters below the thin ore horizon. At a depth of 16 meters a water-saturated zone probably at the base of the Kelley Hollow flow was penetrated. An interbed between the Kelley Hollow and high-Mgo flows apparently is an aquatard and active lateral groundwater flow has developed above it. The flow of water into the auger hole mixed with auger samples moving up the hole and produced a soft, wet mud that emanated from the hole during the next 6 meters of augering. The mud was initially light brown but it soon changed to a pinkish brown due to the influence of pink to reddish cuttings of high Mgo basalt Only one sample of the high Mgo flow, from near the bottom of the hole, was taken during the completion of augering.

A traverse from the level of the I-5 frontage road down to the level of I-5, about 20 meters of relief, supplemented the auger data. Above the interbed a polygonal pattern formed after basalt pillows was visible in the fresh smooth faces of the new road cut (Figure 17). The interbed varied from 2 - 3 meters thick and undulated markedly along the face of the road cut. Within the underlying high Mgo flow relict basalt textures and structures are better preserved than in the Kelley Hollow flow. The color of the clays is pink to white as opposed to the characteristic 


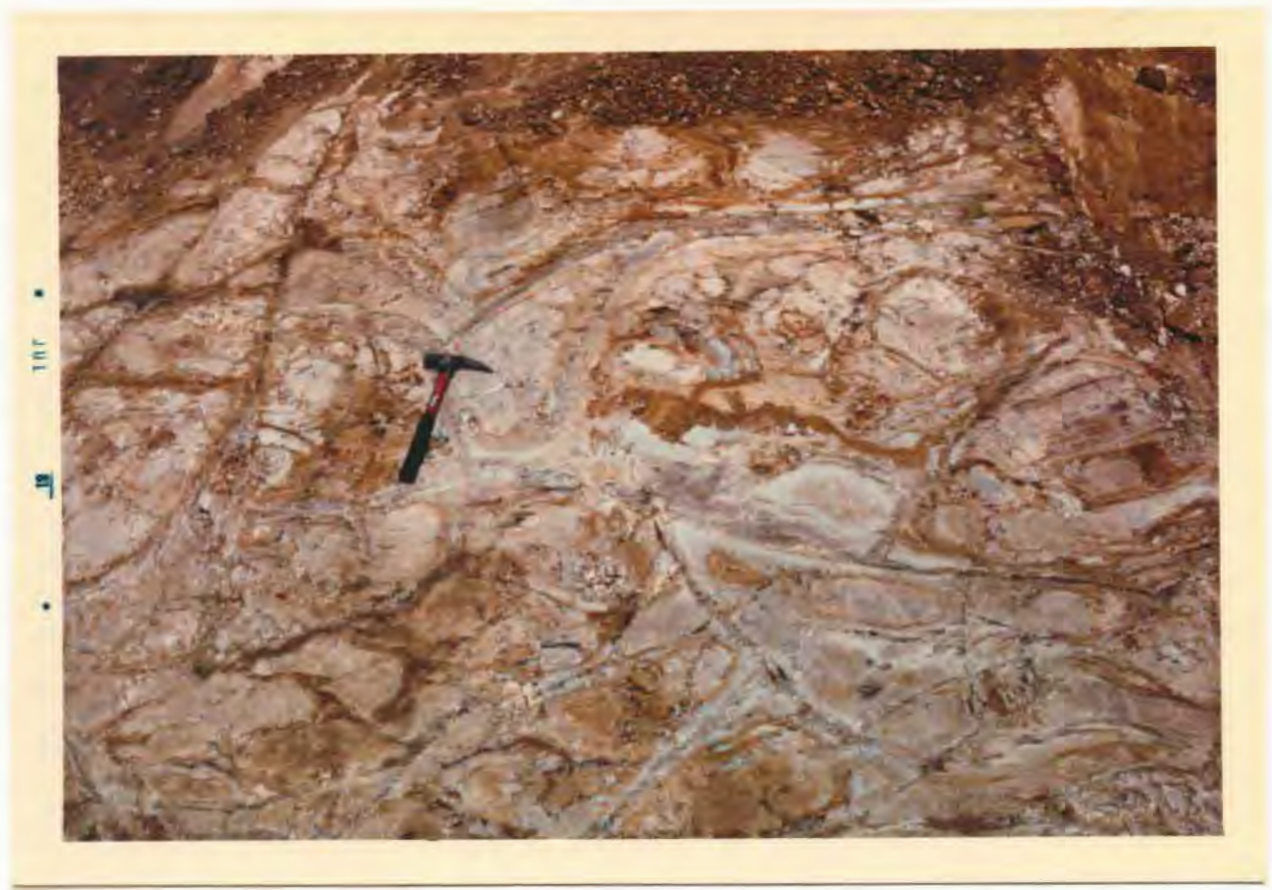

Figure 17. Weathered pillows at base of Kelley Hollow flow along I-5 frontage road just south of Sunnyside interchange.

orange color of the kelley Hollow clays. The concentration of $\mathrm{Fe}_{2} \mathrm{O}_{3}$ also changes significantly from the upper to the lower flow. This is believed to relate to an initial $3 \%$ difference in $\mathrm{Fe}_{2} \mathrm{O}_{3}$ concentration for the two flows (Table I, page 38). As the iron enrichment due to weathering nearly doubles the concentration of $\mathrm{Fe}_{2} \mathrm{O}_{3}$ the $3 \%$ initial difference becomes about $6 \%$ and the change across the boundary becomes significant. Large weathering spheroids, some of hard, gray basalt, commonly occur within several meters of the top of the high Mgo flow and continue to the base of the exposure. Many of these spheroids contain 
clay-filled fractures (Figure 18). The lowermost sample in this profile (TFT 7) was interspheroidal material consisting of halloysite and gibbsite. Chemical analysis of this sample indicates a high $\mathrm{Al}_{2} \mathrm{O}_{3}$ content, over $35 \%$, and a similar $\mathrm{SiO}_{2}$ concentration. The occurrence of gibbsite at a low stratigraphic level in the profile suggests that the same processes forming bauxite at higher levels might have operated at depth along fractures or other zones of ground water movement.

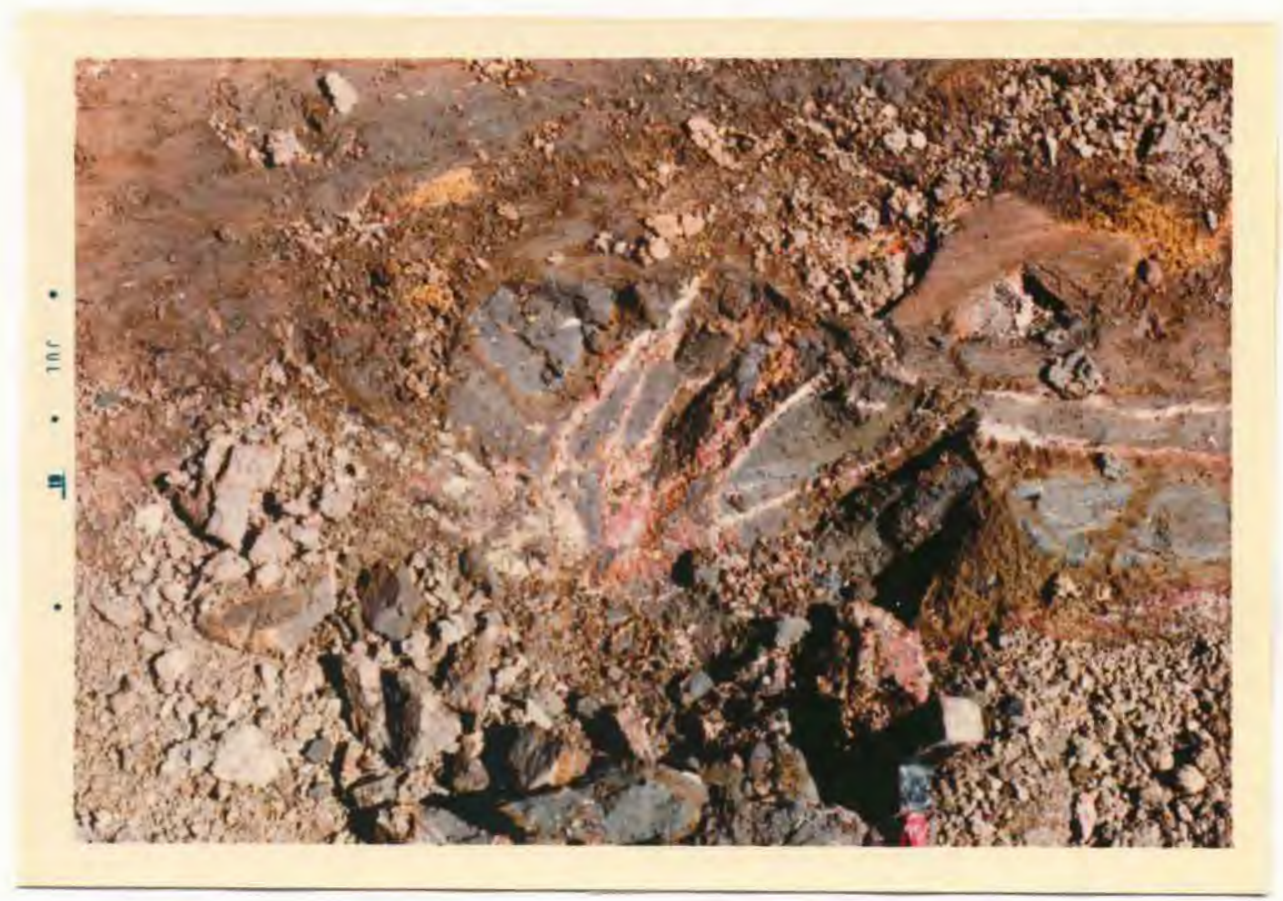

Figure 18. Clay-filled fractures in basaltic corestone from the high MgO flow of the Turner Freeway profile. 


\section{PROSPECT HILL PROFILE}

This profile, and the next one to be discussed, cannot be confirmed by observations made from outcrops. The general stratigraphic context of the hole, however, was provided by a sample of winter water flow collected from outcrop about 75 meters below the summit of Prospect Hill. As mentioned in an earlier section, one of the interests for drilling on the western margin of the Salem Hills was to determine if the Kelley Hollow flow had advanced into this area. A change in the concentration of $\mathrm{Fe}_{2} \mathrm{O}_{3}$ at the 4.6 meter depth in this profile (Figure 19) is similar to the change at the high MgO - Kelley Hollow contact in the Turner Freeway profile. In addition a coloration change in the clays from orangish to reddish tends to confirm that the Kelley Hollow-high MgO contact is present in the Prospect Hill profile. The contact zone is wet but there is no evidence for an interbed.

Mineralogical data is most complete for this profile. Gibbsite is common above the inferred contact, however, it ceases to occur below the contact and halloysite begins to occur. Kaolinite is found in association with both gibbsite and halloysite. Again metallic oxides are prevalent through most of the profile. A sample (PHN 1) of gibbsite nodules 


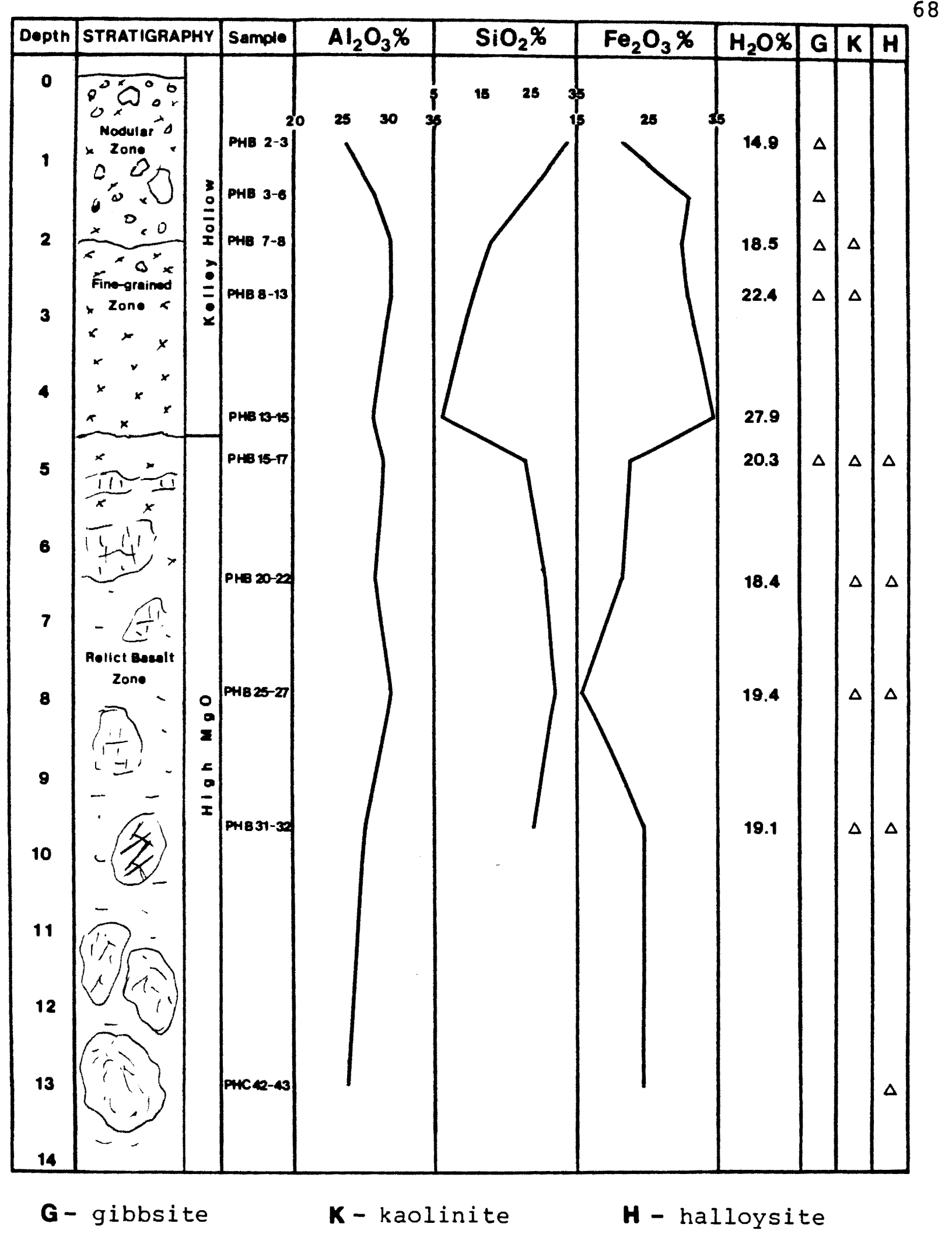

Figure 19. Prospect Hill laterite profile 
which were abundant as float on the surface around the drill site was analyzed and contained $50.08 \mathrm{Al}_{2} \mathrm{O}_{3}, 5.58$ $\mathrm{SiO}_{2}$ and $15.28 \mathrm{Fe}_{2} \mathrm{O}_{3} \cdot$ Pure gibbsite contains about $65 \%$ $\mathrm{Al}_{2} \mathrm{O}_{3}$ and about $358 \mathrm{H}_{2} \mathrm{O}$.

The analyses of the cuttings from the Prospect Hill auger hole indicate a thin ferruginous bauxite zone from 2 to about 4 meters beneath the surface. A thin reddish soil zone occurs above this orangish-red ferruginous bauxite. The underlying weathered material is brownish near the top but is mostly reddish to reddish brown. Corcoran and Libby (1956) reported a 3 -meter-deep auger hole at this location but no ore was indicated because of a $21.3 \%$ average $\mathrm{SiO}_{2}$ concentration.

\section{REESE HILL PROFILE}

As mentioned above, 7.5 meters of ferruginous bauxite ore are contained in this profile (Figure 20). The ore zone is overlain by a 5 -meter-thick reddish-brown clay-rich soil zone that is similar to zones overlying low-silica horizons in the other two profiles. Small gibbsite nodules are present in the lower portions of the reddish-brown clay-rich zone, suggesting a similarity to Hook's nodular zone. The low silica 


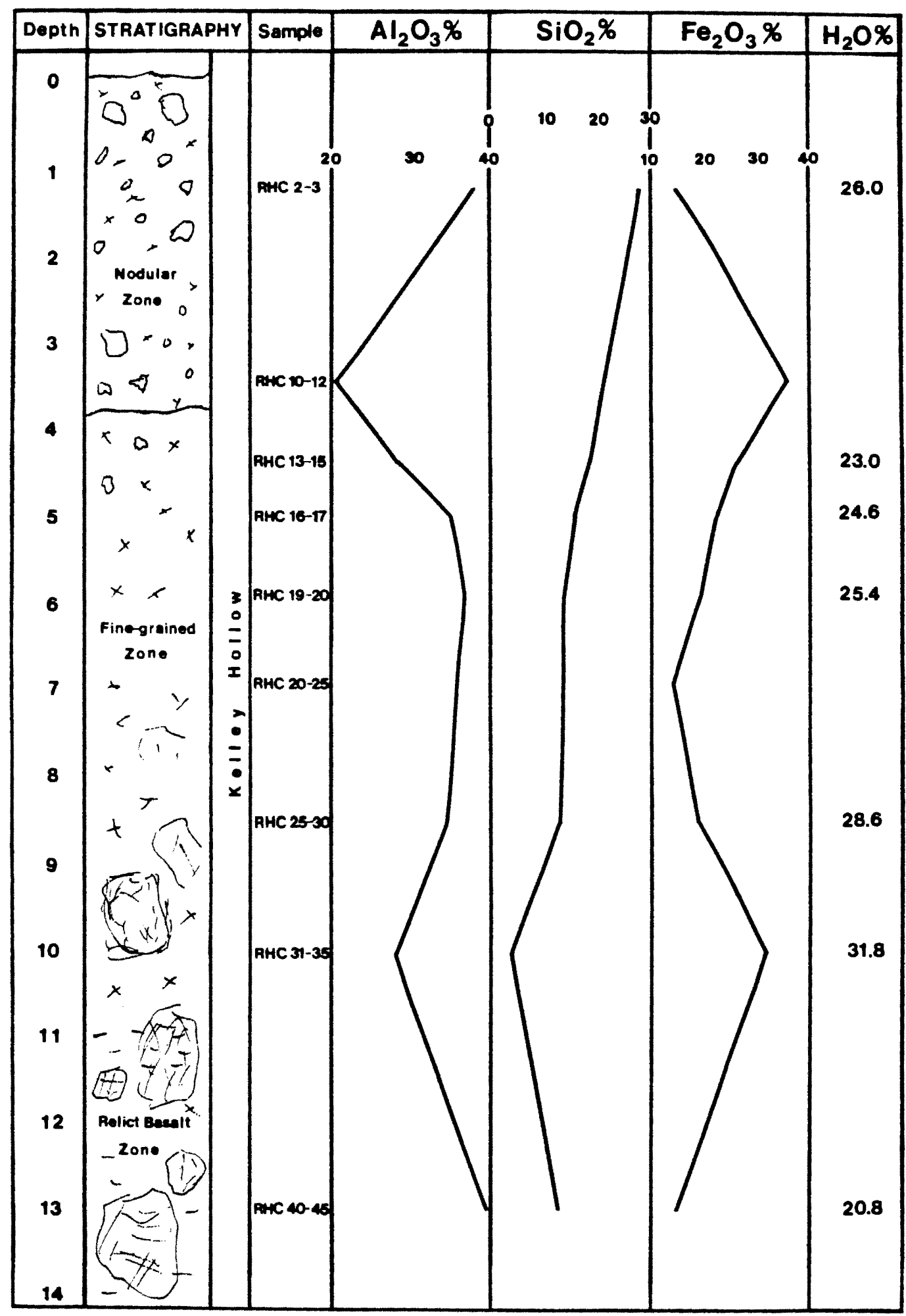

Clay Mineralogy not determined for this profile

Figure 20. Reese Hill laterite profile 
zone would then correspond to the fine-grained zone of the generalized profile.

At a depth of 9 meters the core drill cut the edge of a weathering spheroid which exhibited three distinct concentric zones. The inner zone is fresh basalt and identifiable as being of the Kelley Hollow flow on the basis of overall texture and the presences of plagioclase glomerocrysts. Ferruginous bauxite ore samples above and below this corestone suggests that its location with respect to the generalized stratigraphy is above the relict basalt zone. Hard saprolitic material occurs in the lowermost part of the profile and would represent the relict basalt zone. Neither lithologic nor geochemical evidences suggest the presence of the high Mgo flow within this profile.

\section{ENCHANTED FOREST TRAVERSE}

To test lateral variation of geochemical values within apparently consistent materials, an exposure with good lateral continuity was sampled. The location, sampling plan, and results are shown in Figure 21. A somewhat unsettling result of this experiment is the analysis of sample EFT 1. This sample is one of the highest grade ore 

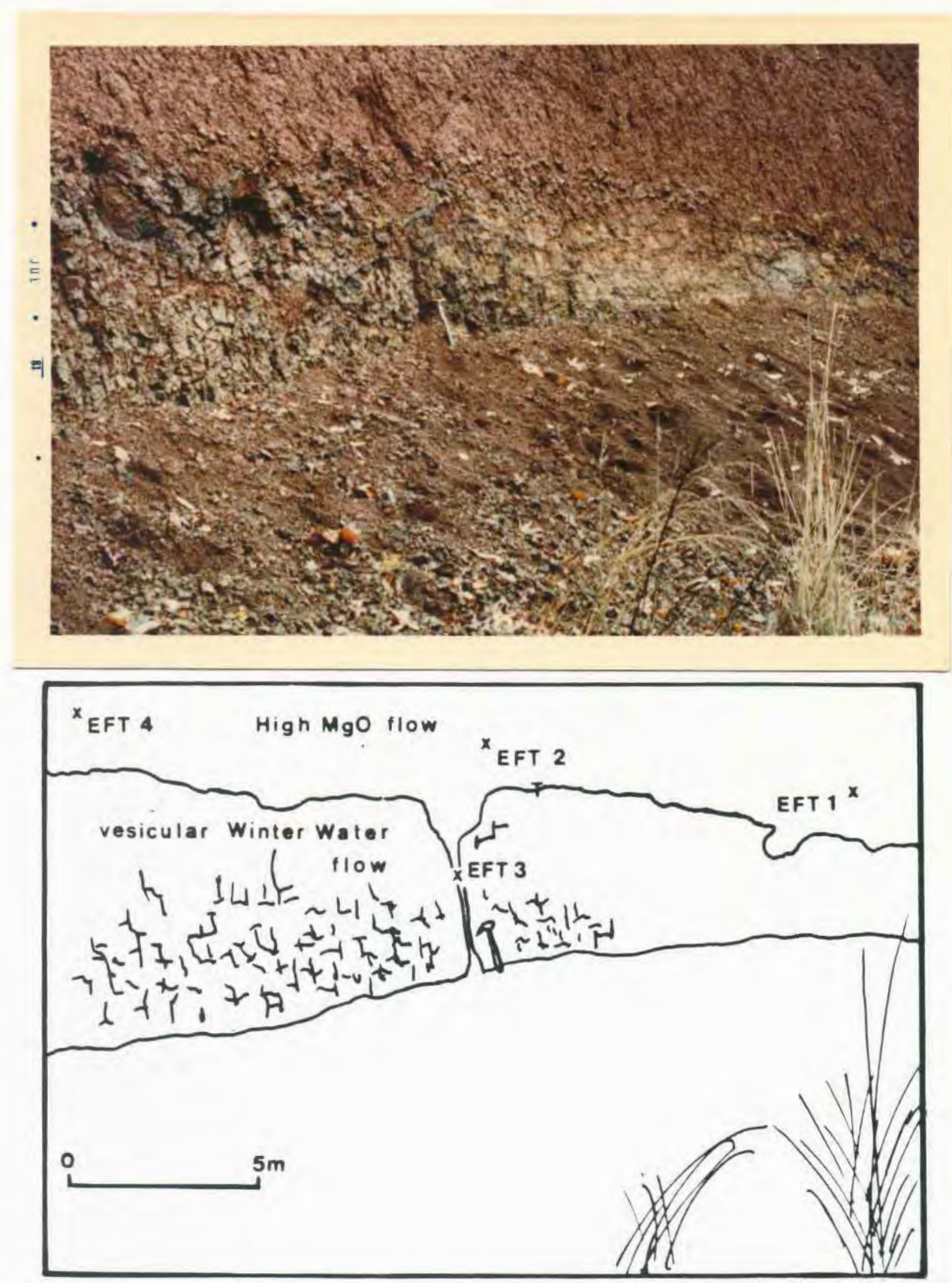

$\begin{array}{lllll} & \text { EFT } 4 & \text { EFT } 3 & \text { EFT 2 } & \text { EFT 1 } \\ \mathrm{Al}_{2} \mathrm{O}_{3} \frac{8}{8} & 24.1 & 25.7 & 30.5 & 36.6 \\ \mathrm{Fe}_{2} \mathrm{O}_{3} \text { \% } & 20.3 & 21.0 & 20.3 & 21.3 \\ \mathrm{SiO}_{2}{ }^{8} & 33.8 & 32.1 & 17.82 & 12.0\end{array}$

Figure 21. Enchanted Forest traverse sampling scheme and major oxide concentrations 
samples analyzed for the study and occurs within laterized Grande Ronde basalt; it is believed to reflect a localized effect and not a significant lack of lateral continuity. The other three samples have relatively consistent chemical compositions.

A vesicular saprolite (Figure 22 ) in the section is developed from the Winter water flow as indicated by lateral tracing of this outcrop to identifiable winter water flow. The identification of the parent basalt type of the overlying reddish-brown soil is uncertain. It may be either the high Mgo flow or the Winter Water flow. The similar chemistry of the fracture filling material to that of two of the other samples suggests that it results from the same parent material. This would, in turn, indicate that the reddish-brown soil is highly weathered winter water material and that the contact is high in the outcrop. On the other hand, if the high Mgo and Winter water flows yield very similar weathering products, the material developed along the fracture could be from the winter water flow and the overlying soil could be of high Mgo origin. Additional data is need to answer the question. 


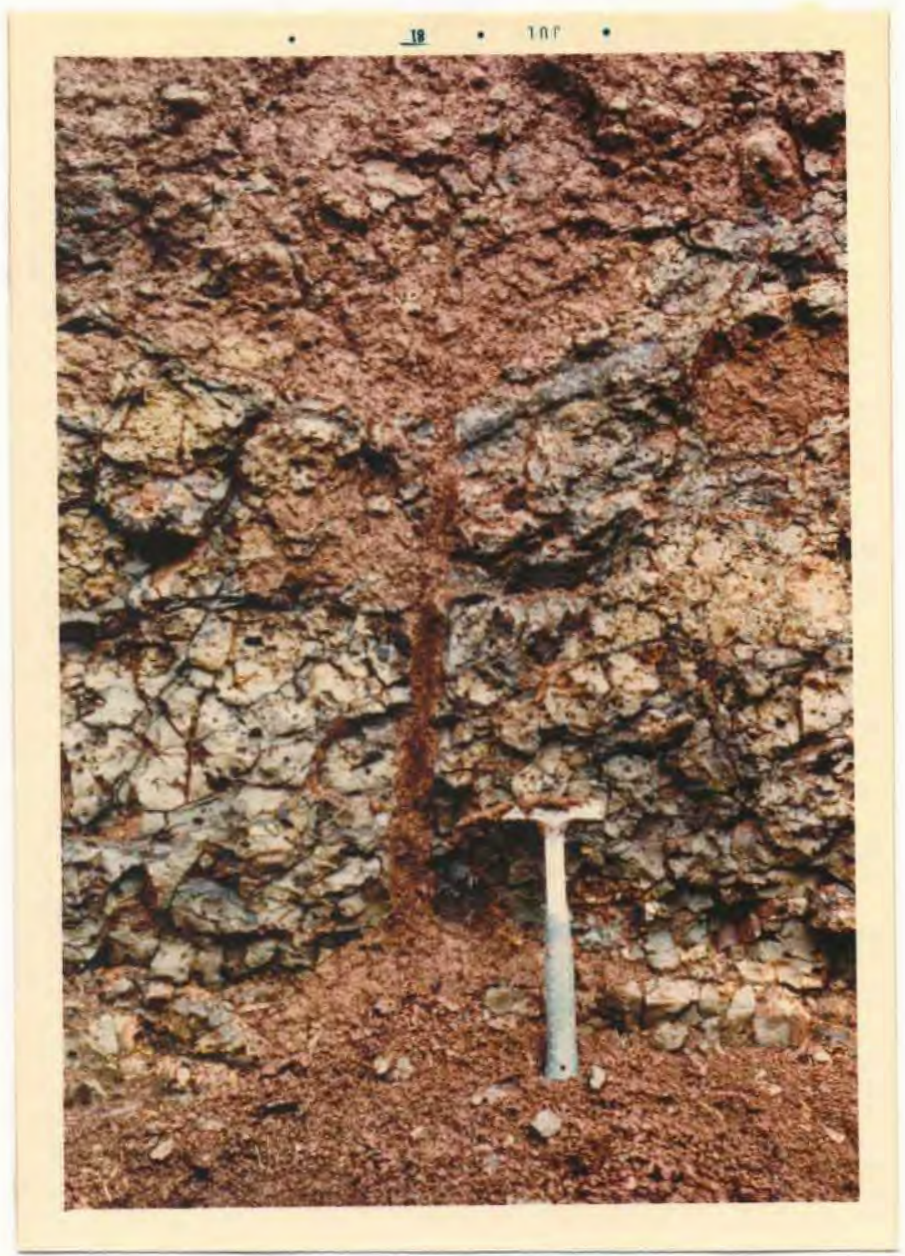

Figure 22. Vesicular saprolite of Enchanted Forest traverse. 


\section{GEOCHEMISTRY OF LATERITE PROFILES}

Twelve elements, determined by $x$-ray fluoresence (XRF) and instrumental neutron activation analysis (INAA), were considered to be of potential use in the interpretation of the processes associated with laterization of basalt. These elements tended to be significantly enriched or depleted relative to their concentrations in unweathered basalt. Some would vary from enrichment to depletion over short stratigraphic distances. Elements which were determined for all or some samples and not considered to be significant to the interpretation of the profiles were $\mathrm{Na}_{2} \mathrm{O}, \mathrm{MgO}$ and several trace elements. $\mathrm{Na}_{2} \mathrm{O}$ and $\mathrm{MgO}$ were present in concentrations on the order of $100 \mathrm{ppm}$ (as compared to several per cent in the parent material) and exhibited minimal variation. The fact that these elements are so thoroughly depleted is important to note, but this is totally expected in such environments. A very narrow range $(3.0 \pm 0.28)$ of concentrations for titania in the samples suggests analytical errors and thus these data have been disregarded (further discussion in Appendix C).

The geochemical data are plotted in Figure 23 as a ratio of element concentrations in weathered material to the average concentration for unweathered parent rock 
Ratio to parent meterial
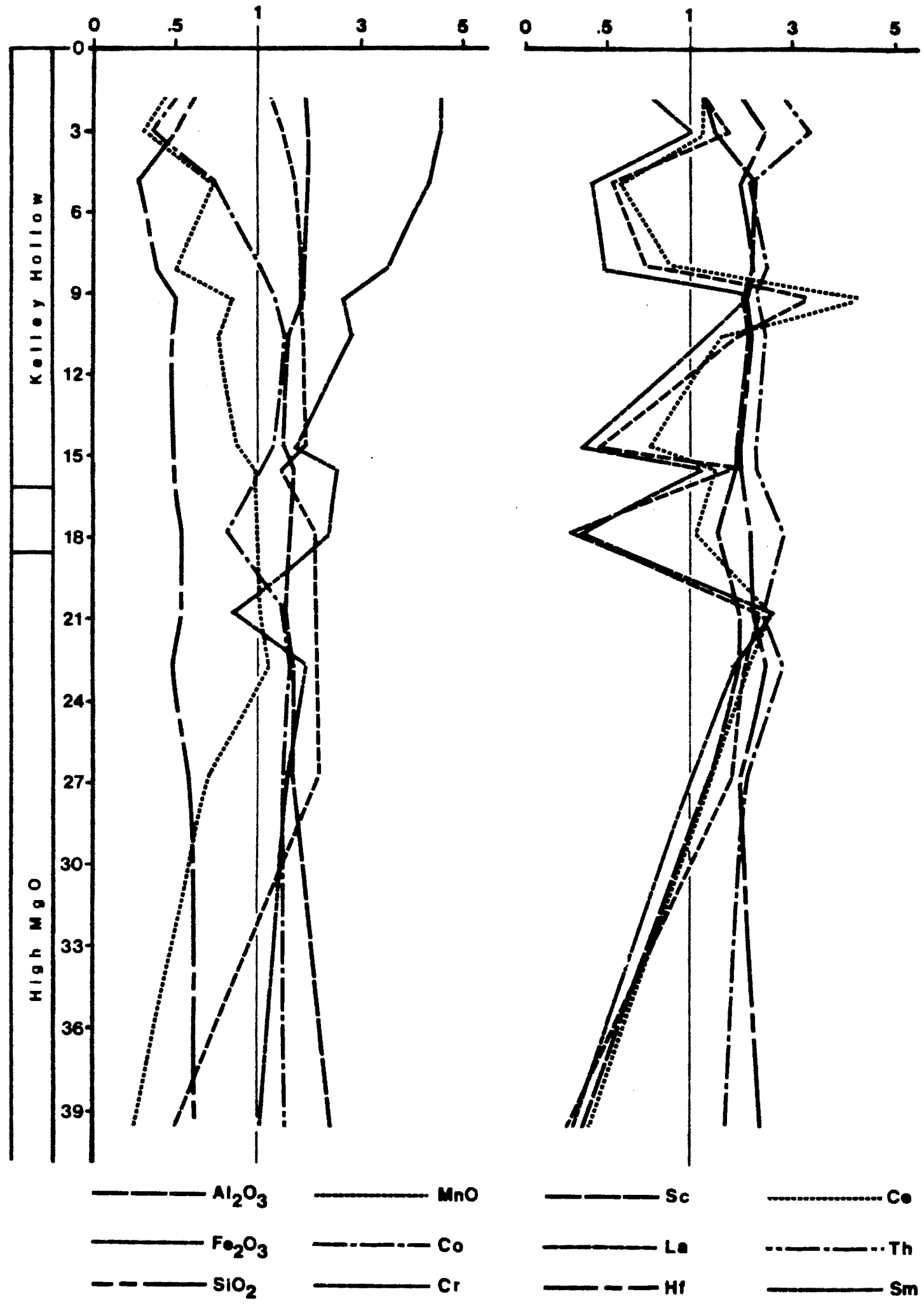

Figure 23a. Turner Freeway geochemical profile 
Ratio to parent material
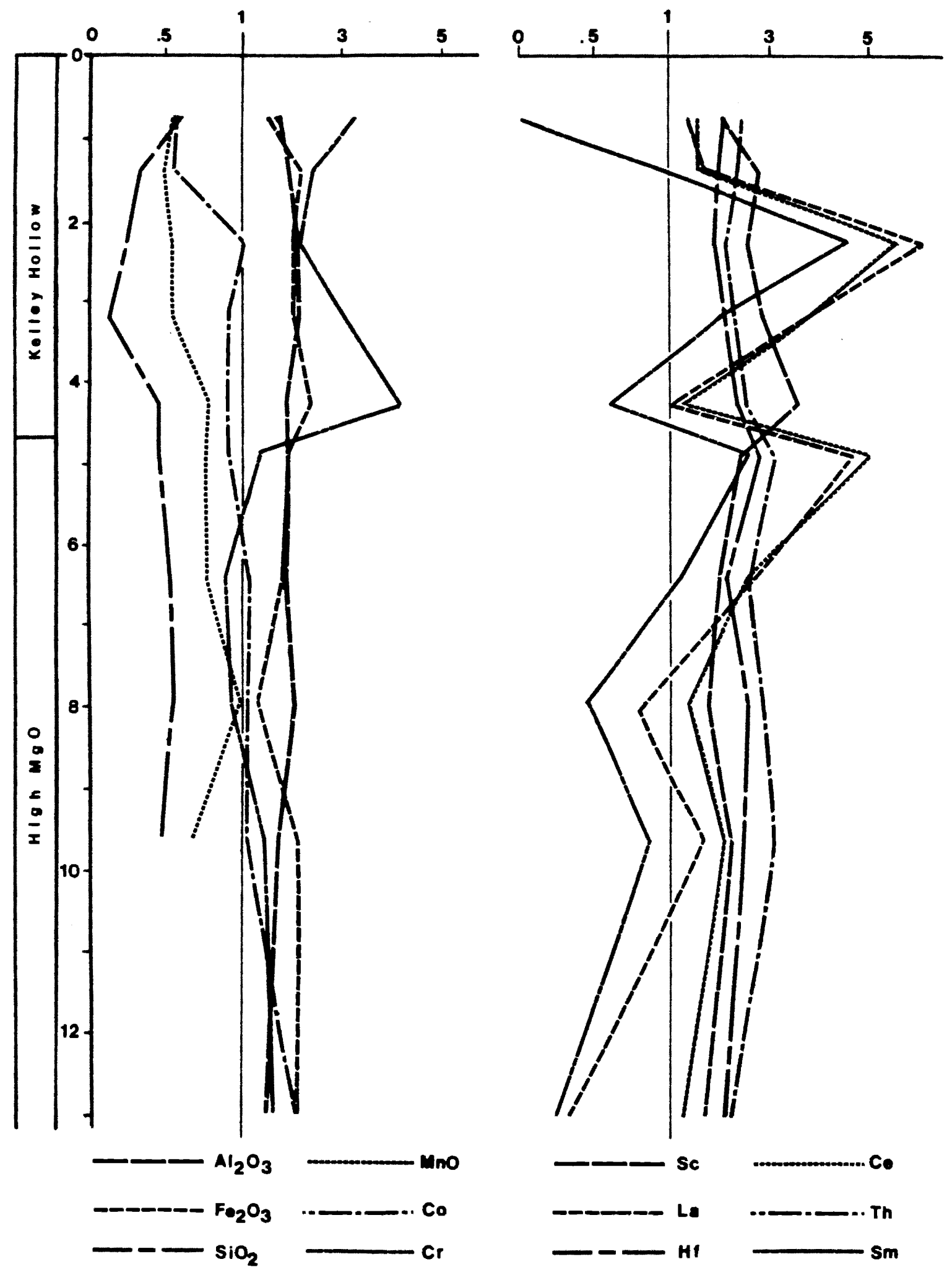

Figure 23b. Prospect Hill geochemical profile 
netio to parent material

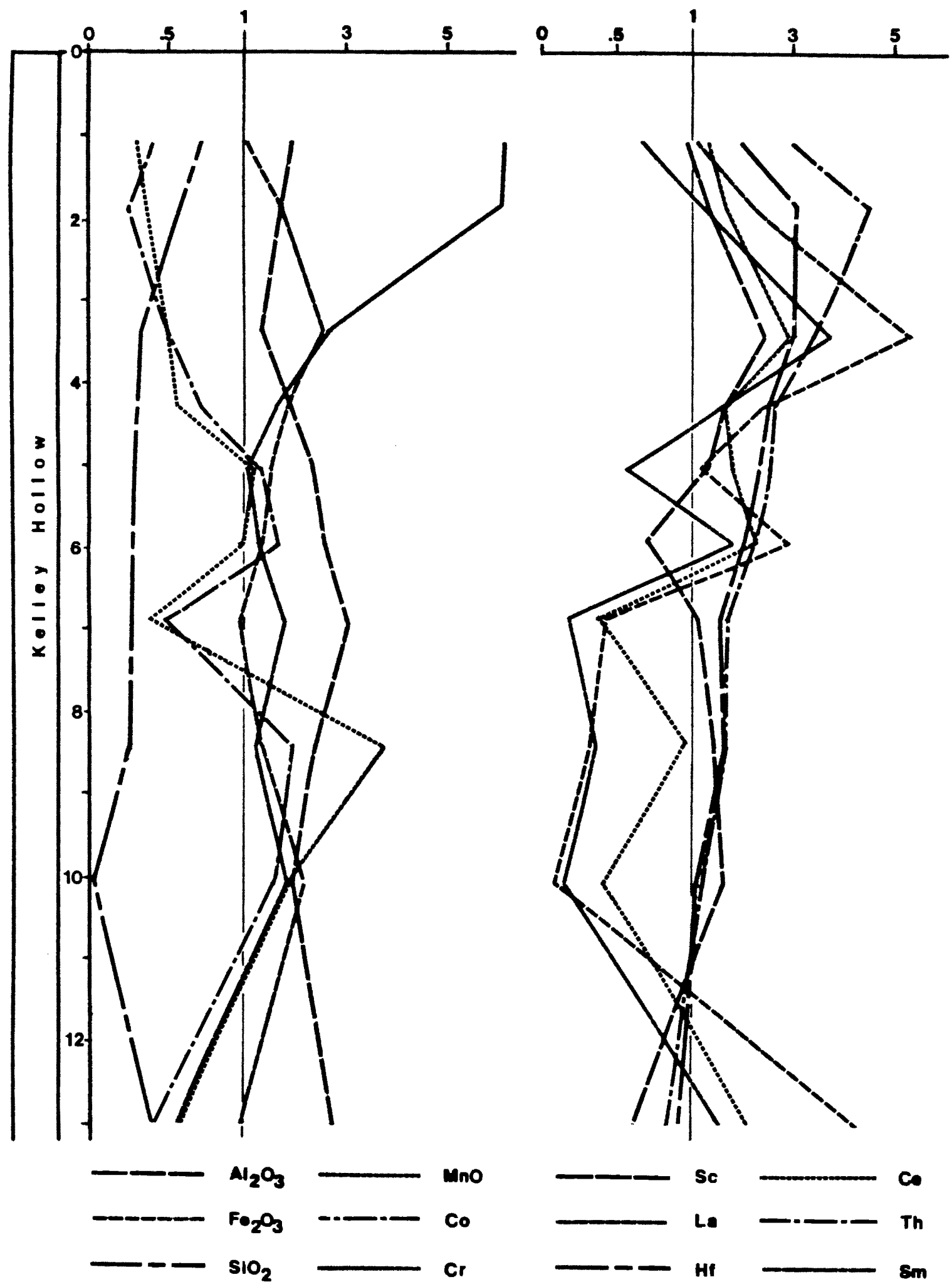

Figure 23c. Reese Hill geochemical profile 
(Basalt Geochemistry section) versus depth for the three profiles. Changes in the composition of parent basalts in the Prospect Hill and Turner Freeway profiles are included in the ratio calculations. Except for $\mathrm{Cr}$, concentration differences observed between flows are minor in comparison to the concentration differences between basalts and derivative laterites.

The reader is cautioned to bear in mind that water will comprise up to 358 of the weathered materials and average about 208. The concentrations have not been recalculated to a water-free basis as was done in a similar study by Harden and Bateson (1963). Such recalculation would seem to unduly exaggerate concentrations of the non$\mathrm{H}_{2} \mathrm{O}$ constituents of the laterites and, hence, the ratios to parent materials. For reference, the estimated $\mathrm{H}_{2} \mathrm{O}$ content is shown on the laterite profiles of the previous section. The estimated $\mathrm{H}_{2} \mathrm{O}$ is equal to 1008 minus the sum of the four major oxides plus 48 for titania and minor elements.

Several patterns are observed in the geochemical profiles. The most distinctive is the sympathetic and erratic behavior of the rare earth elements (REE) La, $\mathrm{Ce}$, and $\mathrm{Sm}$. A second sympathetic pattern can be demonstrated for Sc, Th, and $\mathrm{Hf}$, although the concentration ratio of Sc 
is sometimes variable from those of $\mathrm{Hf}$ and $\mathrm{Th}$ (usually in the near surface weathering environment). Mno and co also exhibit similar behavior. The consistency of the concentration ratios for this third group with depth is intermediate to that of the REE and the SC-Th-Hf group. Ratio curves for $\mathrm{Al}_{2} \mathrm{O}_{3}$ and $\mathrm{Fe}_{2} \mathrm{O}_{3}$ can also be considered as a pair, but from the standpoint of dissimilar behavior with depth. These two curves tend to increase and decrease out of phase, often crossing and thus developing a "weave" pattern in the profiles. Except for the progressive concentration of $\mathrm{Cr}$ in the upper parts of the profiles no behavioral patterns which relate to other elements are discernable for $\mathrm{Cr}$ or $\mathrm{SiO}_{2} \cdot$ None of the described patterns appear to be particularly related to each other or to ferruginous bauxite ore horizons.

One aspect of these data that is potentially significant is that variations are much greater in the Kelley Hollow flow than in the high MgO flow. The REE in particular demonstrate this point. There would seem to be three possible explanations for increased variability within the Kelley Hollow flow. First, since the Kelley Hollow is at the surface in all these profiles, the association of this flow and a higher degree of geochemical variation may simply be a near surface phenomenon. But the high degree of variability persists to a different depth in each 
profile, a depth that corresponds to the base of the Kelley Hollow flow. Secondly, the high degree of variability may be inherited from the parent material. The relative few Kelley Hollow samples analyzed for this study are not a sufficient number to conclusively support or deny this possibility, but analyses of Kelley Hollow flow samples from other areas offer no suggestion of such inhomogeneity. Thirdly, some physical property of the Kelley Hollow flow may control the distinctive geochemical behavior. Perhaps the coarse, blocky jointing pattern of the Kelley Hollow flow could be a factor in that ground water would tend to be channelized in this flow. A cross section would thus penetrate zones of highly variable material ranging from fresh corestones to strongly weathered basalt. Although the high Mgo also tends to develop a blocky joint structure, the longer period of weathering for this flow may have lessened the sharpness of the joint pattern. The open texture of the high Mgo flow might also be a factor in the weathering profile patterns. This texture would suggest higher porosity and perhaps higher permeability in the high Mgo flow, which could account for a greater diffusion or mixing capability for constituents in solution and for a more pervasive leaching. Grain size differences between the two flows would not be expected to relate to the higher degree of chemical variation in the Kelley Hollow flow 
although the coarse-grained nature of these two flows is probably a factor in their susceptibility to chemical weathering. 


\section{DISCUSSION}

A great many factors are involved in the development of bauxite deposits. Papers by Norton (1973), Peterson (1971), and Harder (1949) provide a comprehensive review of the subject. Generally recognized controls include parent material, climate and vegetation, topography, and time, all of which can interrelate in innumerable ways. Many potential parent materials have sufficient $\mathrm{Al}_{2} \mathrm{O}_{3}$ concentrations and a lack of iron and free silica, which are difficult to remove during weathering, but they do not weather to form bauxite deposits because other conditions are not favorable. A wet and warm climate is effective in forming bauxites, but only if 1 ) vegetative cover is heavy so as to produce organic acids in the ground water environment and 2) drainage is adequate to ensure removal of leachate from the bauxite-forming environment. Along with good drainage, erosion must be minimal, so as not to remove the potential deposit. Thus, optimum conditions for the formation of bauxite are a parent material that is high in alumina and low in iron and free silica, a humid tropical climate, lush vegetation, and a well drained but non-actively eroding topography. 
Bauxitization involves the removal of silica and iron and the residual concentration of alumina. Geochemical conditions which promote this process within the weathering environment can be best illustrated by relative solubility equilibria of silica, alumina, and iron. The concentrations of these elements relative to their concentrations in parent material will, of course, be affected by the amounts of readily soluble elements such as the alkalies and alkaline earths which are removed from the system. Analyses from this study have shown such leaching to be relatively complete within the study profiles. Thus, marked changes in the concentrations of $\mathrm{SiO}_{2}, \mathrm{Al}_{2} \mathrm{O}_{3}$, or $\mathrm{Fe}_{2} \mathrm{O}_{3}$ in the laterites must be accredited to environmental conditions which effect the solubilities of these elements. The environmental conditions of most interest in bauxite genesis are $\mathrm{pH}, \mathrm{Eh}$, and the concentration of dissolved silica.

Release of silica from silicate minerals and its leaching within the weathering enviornment is generally considered to occur at a consistent and modest rate under conditions of $\mathrm{pH}<10$. The kinetics of the reaction are dependent upon the removal of products, i.e. so long as silicic acid $\left(\mathrm{H}_{4} \mathrm{SiO}_{4}\right)$ concentrations and $\mathrm{pH}$ conditions are sufficiently low silica leaching will proceed. The fulfillment of both of these conditions is enhanced by an active ground water system. Rainwater $\mathrm{pH}$ is normally in 
the range of 5.5-6.5 (Garrels and Christ, 1965). Thus, removal of leachate will also serve to ensure that the maintenance of $\mathrm{pH}$ conditions at a sufficiently low level to promote silica depletion from the parent rocks.

Eh-pH solubility relationships for the $\mathrm{Fe}-\mathrm{H}-\mathrm{O}$ and Al-H-O systems are shown in Figure 24. The combination of these two diagrams as shown in Figure 25 (Peterson, 1971) serve to illustrate conditions during the formation of a ferruginous laterite (field $A$ ), ferruginous bauxite (field B), and bauxite (field C). Note that alumina solubility is Eh independent, with gibbsite being stable between $\mathrm{pH}$ of about $3-4$ and 10 ; and that iron is both $\mathrm{pH}$ and Eh dependent.

Within the Turner Freeway and Prospect Hill profiles (Figures 15 and 19 , pages 61 and 68) the behavior of $\mathrm{Al}_{2} \mathrm{O}_{3}$ and $\mathrm{Fe}_{2} \mathrm{O}_{3}$ is relatively simple. These profiles have apparently developed under pH-Eh conditions of field B. Eh-pH conditions throughout these profiles were primarily those of field B where iron and alumina are insoluble. The sample at the base of the Turner Freeway profile (TFT 7) suggests conditions of field C since gibbsite is present and $\mathrm{Fe}$ is depleted and conditions of field $\mathrm{A}$ maybe inferred for the lowermost sample of the Prospect 

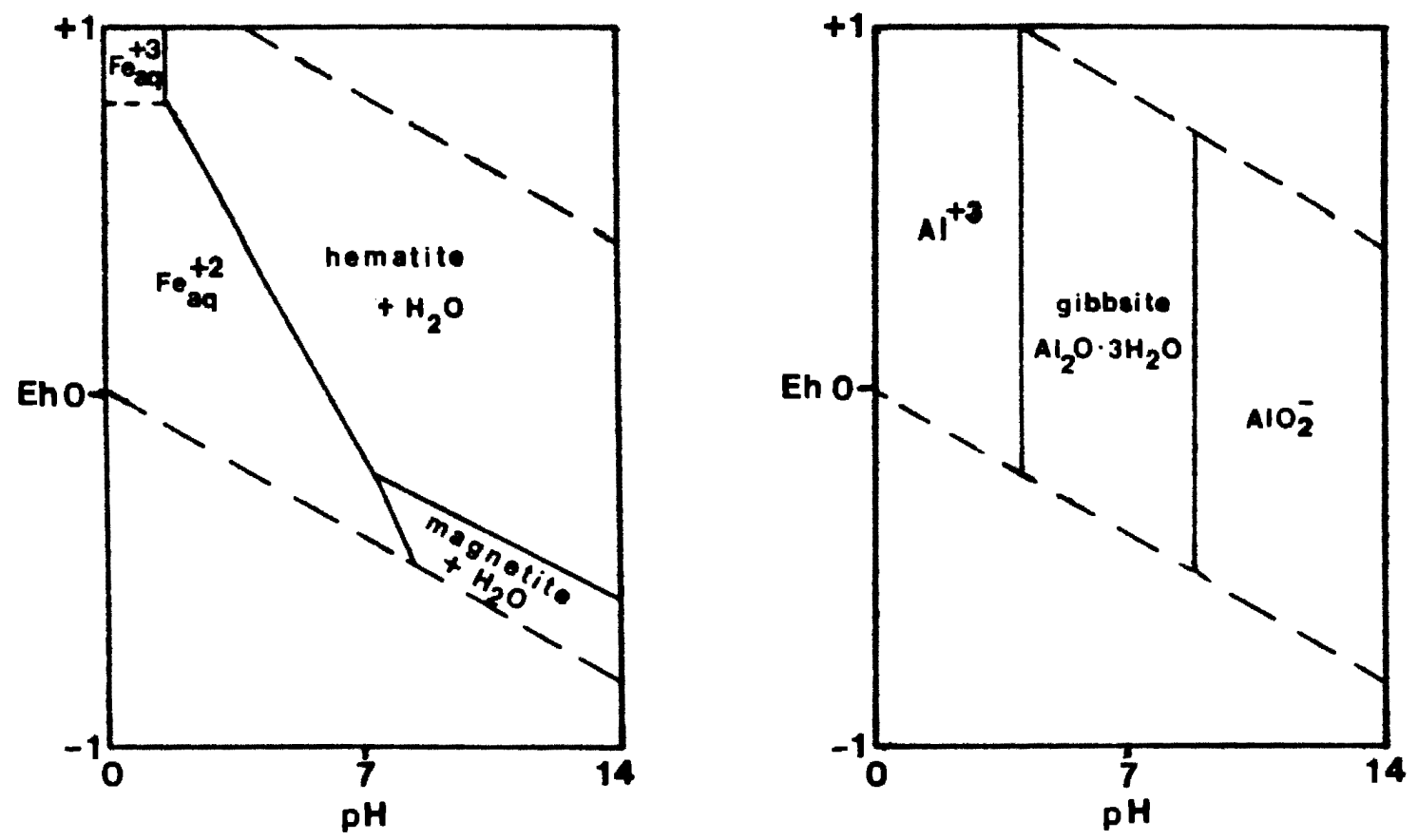

Figure 24. Eh-pH stability for the systems F-O-H (after Garrels and Christ, 1965) and Al-O-H (after Pourbaix, 1966)

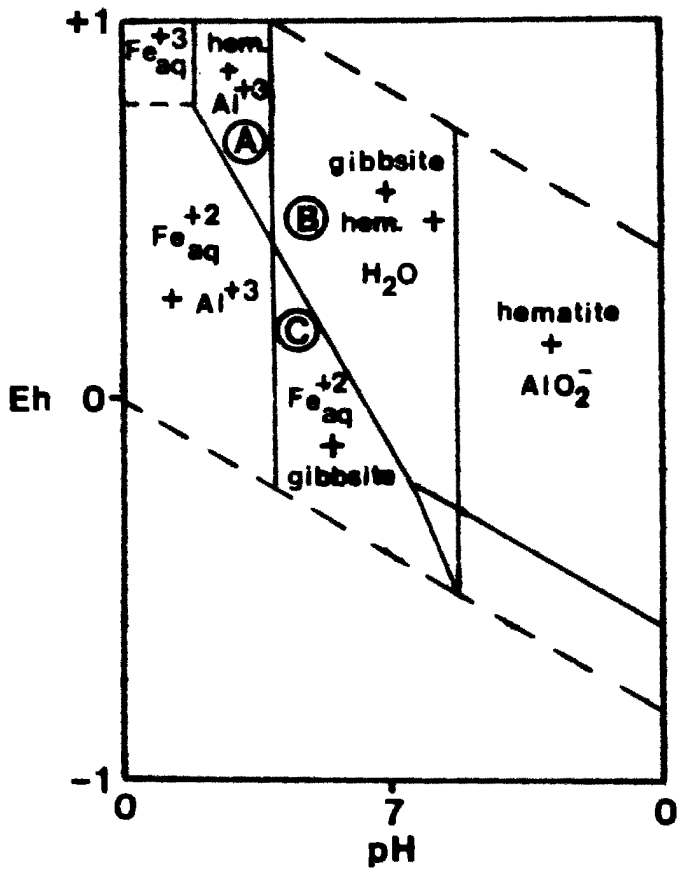

Figure 25. Combined diagrams of Figure 24 
Hill profile (PHC 42-43) because iron is somewhat enriched and aluminia is depleted.

Silica depletion is not dependent on iron and alumina solubility and cannot be related to the preceding discussion zones of decreased silica concentration are inferred to reflect increased removal of silica leachate but not necessarily changing Eh-pH conditions.

The variations in iron and alumina concentrations in the Reese Hill profile (Figure 20, page 71) imply significant variation of $\mathrm{Eh}$ and $\mathrm{pH}$ conditions during the formation of laterite. The iron-alumina relationships of the middle and lower portions of the profile indicate that conditions shown by field $C$ were present in these zones. Between these zones the profile is characterized by weathering conditions represented by field B.

Equilibria data relating to the solubility of other elements of the laterite profiles within the weathering environment are sparse in the literature. The REE pattern is perhaps the most intriging of those in the profiles. It does not appear to relate to the $\mathrm{pH}-\mathrm{Eh}$ solubility fields of iron and alumina, but this does not exclude $\mathrm{pH}-\mathrm{Eh}$ changes from being responsible for variations in the REE. The possibility that the REE are more sensitive than other 
elements to environmental changes and that this may account for their erratic behavior cannot be ruled out. Hf, Th, and Sc, which generally exhibit a slight increase in concentration toward the surface tend to show the least variation in concentration through the profiles. These elements are apparently relatively unaffected by variations in $\mathrm{Eh}$ and $\mathrm{pH}$.

$\mathrm{Cr}$ is generally considered to be quite resistant to weathering and thus would be expected to exhibit the same type profile as Hf, Th, and Sc. But it does show considerable variation in concentration, increasing significantly in the upper portions of the profiles.

Detailed quantitative mineralogical data would seem to be the best approach to the problem of trace and minor element distribution through the laterite profiles. The minerals which are hosting these elements must be considered so the stability equilibria may be examined. Even then existing experimental data may still be insufficient to provide adequate insight to the problem.

Considerable experimental work has been done on the dissolution of feldspar in the weathering process and on how it relates to the formation of bauxite (Berner and Holdren, 1977; Parham, 1969; Wollast, 1967). The first formed weathering product is an amorphous alumina-silica gel 
known as allophane. Wollast (1967) showed that allophane will alter to either kaolinite or a bauxite mineral, boehmite, depending on whether the dissolved silica content in the external solution is greater or less than about 5 mg/l, respectively. A study by Parham (1969) suggests that halloysite rather than kaolinite might be the product formed after allophane. Both halloysite and kaolinite can alter to gibbsite with removal of silica from their structure. Thus, two processes are recognized in the development of bauxite; one involves the development of an alumino-silicate mineral(s) as an intermediate product between the allophane and bauxite mineral and the other does not.

Siefferman and Millot (1969) studied the genesis of soils over basaltic rocks in three different climatic zones of equatorial western Africa. Zone 1 was an always humid equatorial climate on a mountain flank. Zone 2 was a moderate equatorial climate with a dry season and also on a mountain flank, and zone 3 was a tropical climate with a well marked dry season located on a plateau. The authors were able to discern two weathering mineralogical sequences:

1) parent material $\rightarrow$ allophane $\rightarrow$ kaolinite $\rightarrow$ gibbsite (Zone 1)

2) parent material $\rightarrow$ allophane $\rightarrow$ halloysite $\rightarrow$ kaolinite $\rightarrow$ gibbsite (Zones 2 and 3 ). 
The conclusions that may be drawn from their results are that 1) the formation of halloysite requires a dry season and, 2) dissolved silica content less than $5 \mathrm{mg} / \mathrm{l}$ is not likely during the weathering of basaltic materials, even in the wettest and best drained natural conditions, because there is a product intermediate to allophane and gibbsite in all cases.

The presence of halloysite in the Salem Hills laterite profiles suggests that a dry season was part of the typical climatic condition for the area during the development of bauxite. The Prospect Hill profile, in particular, demonstrates the halloysite $\rightarrow$ kaolinite $\rightarrow$ gibbsite pattern which is expected with increasing weathering (Figure 19).

The blanket hypothesis for the development of Pacific Northwest ferruginous bauxites as it was articulated by Libbey, Lowry, and Mason (1945) would thus appear to be incompatible with a generalized model developed from experimental and investigative evidences. Their concept of a low-elevation basalt plain, lacking in structural or erosional relief is in contradiction to both the general bauxite model and the current knowledge of CRBG history in western Oregon. However, the suggestion that the deposits may have been more extensive than they are now cannot be ruled out on the basis of evidence from the Salem Hills. 
The association of ferruginous bauxite with the Kelley Hollow flow throughout the Salem Hills supports the idea of a formerly more extensive deposit. This flow was originally a continuous sheet over most of the area and, although ferruginous bauxite probably did not form until erosion had removed some of this flow, the deposits could certainly have been more extensive than they are now.

Evidence which supports Hook's model of bauxite formation in response to drainage includes the fact that structural relief was developing in the basalt flows during deposition, the draping of deposits over hilltops, and Hook's observations of increasing laterization adjacent to more youthful valleys. Detailed investigations of these factors was beyond the scope of this study but some data applicable to this model have been collected. The angular unconformities between the marine sedimentary rocks and the winter water flow and between the high MgO and the Kelley Hollow flows indicate the onset of structural development before and during basalt deposition. The amount of structural relief, though, appears to be slight compared to what has developed since basalt deposition.

The amount of topographic relief required for adequate drainage to promote bauxite formation cannot be assessed. Thus the question of whether relief was sufficient for 
bauxitization to be an active process soon after the Kelley Hollow flow was deposited or if it was some period of time after final basalt deposition before bauxitization began in the Salem Hills cannot be determined. The deep weathering horizon and baked contact zone between the winter water and high MgO flows implies that climatic conditions, at least, were favorable for intense weathering prior to Kelley Hollow deposition and that this would probably not be a constraint on the bauxitization process.

Bauxite draping would seem to imply a topographic rather than a stratigraphic control because the draping is discordant to the attitude of the basalt. If topographic undulations were related to structure such draping would be considered stratigraphically controlled, but such is not the case in the Salem Hills. In other cases downslope thickening may have resulted from mass movement of a formerly thicker zone from the top of the hill. The draped reddish zone of the Turner Freeway profile does not appear to be of this type. Drilling in this thicker portion at the Turner Freeway profile would be interesting from the standpoint of observing if the thin ore zone exhibits a similar geometry. The hypothesis that the pisolitic zone common to other Pacific Northwest ferruginous bauxite deposits is absent from the Salem Hills deposits because of erosion or downslope movement is suggested from such thinking. 
Hook's observations of downslope thickening of ferruginous bauxite deposits in southwestern washington may tie to the above ideas but this is difficult to determine without knowing the stratigraphic context of his observations. An intensification of silica leaching due to better drainage is not inconsistent with his observations and model.

Another aspect of the Salem Hills ferruginous bauxite deposits that warrants discussion is their localization to the Salem Hills within the Salem area. Seemingly favorable conditions for ferruginous bauxite development exist in the adjacent Eola Hills and Waldo Hills but in neither area does weathering approach the intensity found in the Salem Hills. The key here is that geologic and topographic settings of the Salem Hills are not both duplicated in either of the adjacent areas. Thus, the deep weathering in the salem Hills may not be so enigmatic as it may seem to be.

In the Eola Hills the topographic setting is very similar to that of the Salem Hills; but the basalt stratigraphy consists of an overthickened accumulation of the dense, fine-grained Winter Water flow as opposed to the relatively thin, coarse-grained, and open textured high MgO and Kelley Hollow flows that cap the Salem Hills. 
Despite good drainage the Winter Water flow would not be expected to weather like its counterparts in the Salem Hills.

In parts of the Waldo Hills the Kelley Hollow flow is exposed as the uppermost flow and, based on the correlation established between ferruginous bauxite and this flow, deposits would be expected here. But, again, there are differences from the Salem Hills. In the Waldo Hills, the Kelley Hollow flow rests on the winter water flow instead of on the high Mgo flow, and, probably of more importance, topographic relief is considerably more subdued.

The question of why ferruginous bauxite deposits are confined to the Kelley Hollow flow within the Salem Hills is also of interest. Bauxitization has certainly reached depths within the Kelley Hollow flow at some locations which would penetrate into the high Mgo flow at other locations. The very strong ground water flow above the interbed in the Turner Freeway profile suggests a possible explanation. The interbed may actually act as a barrier to surface water penetration, diverting flow externally, and thus promote sluggish ground water conditions within the high MgO flow. Under such conditions silica removal would be greatly retarded and the lack of ferruginous bauxite would not be surprising. Even in the case where an interbed 
does not exist, lateral flow would be expected to develop along flow contacts or in the vesicular zones of flow tops. In effect, such flow is not appreciably different than what would be expected in the case of an interbed and similar influences on ferruginous bauxite development would be reasonable to assume. 


\section{CONCLUSIONS}

Ferruginous bauxite deposits within the Salem Hills are very closely associated with the informally named Kelley Hollow flow of the Frenchman Springs Member of the Wanapum Basalt of the Columbia River Basalt Group. A map (Plate 2) which combines basalt distribution with the distribution of laterized areas defined by Corcoran and Libbey (1956) demonstrates this association. Additionally, thickening of the Salem Hills ferruginous bauxite deposits to the northeast corresponds to a thickening of the Kelley Hollow flow.

Twelve major, minor, and trace elements reveal patterns within the three geochemical profiles. The REE, $\mathrm{La}, \mathrm{Ce}$, and Sm; Hf, Th, and Sc; and $\mathrm{MnO}$ and Co form three groups of elements which exhibit sympathetic geochemical behavior. $\mathrm{SiO}_{2}$ and $\mathrm{Cr}$ act individually and $\mathrm{Fe}_{2} \mathrm{O}_{3}$ and $\mathrm{Al}_{2} \mathrm{O}_{3}$ behave variably throughout the profiles. None of the patterns are apparently related to each other or to the development of ferruginous bauxite zones, except for the depletion of $\mathrm{SiO}_{2}$ and the concentration of $\mathrm{Al}_{2} \mathrm{O}_{3}$ as required by the chemical definition of ferruginous bauxite. 
Geochemical variation is markedly greater within the Kelley Hollow flow than in the underlying high Mgo flow and is believed to be related to physical characteristics of the two flows. The coarse, blocky jointing of the Kelley Hollow flow may promote ground water circulation that is more channelized in this flow than in the open-textured high Mgo flow.

Environmental conditions within the laterite profiles are generally a pH above $3-4$ and an Eh greater than 0 . When the pH drops to below $3-4 \mathrm{Al}_{2} \mathrm{O}_{3}$ is depleted from the system and when the Eh drops to below about 0, Fe is depleted from the system. Both of these conditions existing simultaneously are rare in the laterite profiles. Significant depletions of silica requires an active ground water system so that leachate is continually removed from the system.

The bauxite forming process is most likely one that involves the formation of allophane, halloysite, and kaolinite during the alteration of parent material to bauxite minerals. A climate with alternating wet and dry seasons is implied by such a mineralogical sequence.

Hook's hypothesis of ferruginous bauxite forming as a result of the development of youthful topography is best 
supported by the findings of this study. However, an aspect of the blanket hypothesis which should be included in a new model is that the deposits may have been more extensive than they presently are.

Ferruginous bauxite deposits have developed after deposition of the Kelley Hollow flow and after the development of sufficient topographic relief so that ground water circulation within the weathering environment was adequate to maintain a $\mathrm{pH}$ level between about $3-4$ and 10 and to effectively remove silica leachate. In the Salem area such conditions developed in the Salem Hills and the Eola Hills. Ferruginous bauxite deposits developed only in the Salem Hills because the parent material was more susceptible to chemical weathering. Physical characteristics, namely the coarse grainsize, the open texture, and the blocky joint patterns of the Kelley Hollow and high MgO flows had a major influence on the preferential nature of laterization within the Salem area. Compositional variation between the different CRBG flows found in the study area do not appear to be an important factor in the development or composition of the laterite.

The confinement of ferruginous bauxite to the Kelley Hollow flow is believed to be related to lateral ground water flow that developed along flow contacts, especially 
when a clay-rich interbed of the type found in the Turner Freeway profile was present. Such lateral flow retarded the influx of relatively fresh groundwater into the underlying high Mgo flow and thus the leaching of soluble constituents from the high Mgo flow was not as effective as in the Kelley Hollow flow. 


\section{REFERENCES}

Additon, M.K., and Seil, R.O., 1979, Columbia River Basalt Reference Sample: Richland, Washington, Rockwell Hanford Operations Energy Systems Group, 25 p.

Allen, Victor T., 1948, Formation of bauxite from basaltic rocks in Oregon: Economic Geology, v. 43, p. 619-626.

Anderson, J.L., 1978, The structure and stratigraphy of the Columbia River basalt in the clackamas River drainage: Portland, Or., Portland State University M.S. thesis, $136 \mathrm{p}$.

Anderson, J.L., 1980, Pomona member of the Columbia River Basalt Group: an intracanyon flow in the Columbia River Gorge, Oregon: Oregon Geology, v. 42, p. 195199 .

Baldwin, E.M., 1981, Geology of Oregon: Dubuque, Iowa, Kendall/Hunt Company, p. 45-60.

Balster, C.A., and Parson, R.B., 1968, Geomorphology and soils, Willamette Valley, Oregon: Agriculture Experiment Station, Oregon State University, Special Report 265 , p. 1-6.

Beeson, M.H., and Moran, M.R., 1979, Columbia River Basalt Group Stratigraphy in western Oregon: Oregon Geology, v. 41 , p. 11-14.

Bentley, R.D., 1977, Stratigraphy of the Yakima Basalts and structural evolution of the Yakima ridges in the western Columbia Plateau, in Brown, E.H., and Ellis, R.C., eds., Geological Excursions in the Pacific Northwest: Bellingham, Western Washington University Press, p. 339-389.

Bentley, R., Anderson, J., Campbell, N., and Swanson, D., 1980, Stratigraphy and structure of the Yakima Indian Reservation with emphasis on the Columbia River Basalt Group: U.S.G.S. Open-File Report 80-200, 76 p.

Berner, Robert A., and Holdren, George R., Jr., 1977, Mechanism of feldspar weathering: some observational evidence: Geology v. 5, p. 369-372. 
Chaney, Ralph w., 1948, The ancient forests of Oregon: Condon Lectures, Oregon State System of Higher Education, $56 \mathrm{p}$.

Corcoran, R.E., and Libbey, F.W., 1956, Ferruginous bauxite deposits in the Salem Hills, Marion County, Oregon: Oregon Department of Geology and Mineral Industries Bulletin, n. 46,53 p.

Dennen, W.H., and Norton, H.A., 1977, Geology and geochemistry of bauxite deposits in the lower Amazon basin: Economic Geology, v. 72 , p. 82-89.

Durham, J.W., 1950, Cenozoic marine climates of the Pacific coast: Geological Society of America Bulletin, v. 61, p. 1243-1263.

Flannigan, F.J., 1973, 1972 values for international geochemical reference samples: Geochimica et Cosmochimica Acta, v. 37, p. 1189-1200.

Garrels, R.M., and Christ, C.L., 1965, Solutions, Minerals, and Equilibria: New York, Harper and Row, p. 178-211.

Goodwin, Clinton John, 1973, Stratigraphy and sedimentation of the Yaquina Formation, Lincoln County, Oregon: Corvallis, Or., Oregon State University M.M. thesis, $102 \mathrm{p}$.

Gordon, G.E., Randle, K., Goles, G.G., Corliss, J.B., Beeson, M.H., and Oxley, S.S.,1968, Instrumental activation analysis of standard rocks with highresolution gamma ray detectors: Geochimica et Cosmochimica Acta, v. 32, p. 369-396.

Grim, Ralph E., 1953, Clay Mineralogy: New York, McGrawHill Book Company, Inc., 384 p.

Hammond, P.E., Bentley, R.D., Brown, J.C., Ellingson, J.A., and Swanson, D.A., 1977, Volcanic stratigraphy and structure of the southern Cascade Range, washington, in Brown, E.H.; and Ellis, R.C., eds., Geological Excursions in the Pacific Northwest: Bellingham, Western Washington University Press, p. 127-169.

Harden, G., and Batheson, J.H., 1963, A geochemical approach to the problem of bauxite genesis in British Guiana: Economic Geology, v. 58, p. 1301-1308. 
Harder, E.C., 1949, Stratigraphy and origin of bauxite deposits: Geological Society of America Bulletin, v. 60 , p. 887-907.

Hickman, C.J.S., 1969, The Oligocene molluscan fauna of the Eugene Formation in Oregon: University of Oregon Museum of Natural History Bulletin, n. 16, 112 p.

Hook, John W., 1976, Ferruginous bauxites of the Pacific Northwest: Oregon Department of Geology and Mineral Industries Open-File Report 0-76-3, $26 \mathrm{p}$. $26 \mathrm{p}$.

Jackson, R.L., 1971, Description of the ferruginous bauxite ore profile in Columbia County, Oregon: The Ore Bin, v. 33, p. 223-229.

Jackson, R.L., 1974, A mineralogical and geochemical study of the ferruginous bauxite deposits in Columbia County, Oregon, and Wahkiakum County, Washington: Portland, Oregon, Portland State University M.S. thesis, $87 \mathrm{p}$.

Libbey, F.W., Lowry, W.D., and Mason, R.M., 1945, Ferruginous bauxite deposits in northwestern Oregon: Oregon

Department of Geology and Mineral Industries Bulletin, n. 29,93 p.

Lindstrom, M.M., and Haskin, L.A., 1981, Compositional inhomogeneities in a single Icelandic tholeiite flow: Geochimica et Cosmochimica Acta, v. 45, p. 15-31.

Livingston, V.E., 1966, Geology and mineral resources of the Kelso-Cathlamet area, Cowlitz and Wahkiakum Counties, Washington: Washington Division of Mines and Geology Bulletin, n. 54, 110 p.

Mackin, J.H., 1961, A stratigraphic section in the Yakima Basalt and the Ellensburg Formation in south-central Washington: Washington Division of Mines and Geology Report of Investigations, n. 19, $45 \mathrm{p}$.

McKee, Bates, 1972, Cascadia, the Geologic Evolution of the Pacific Northwest: New York, McGraw-Hill Book Company, p. 290-292.

McKee, E.H., Swanson, D.A., and Wright, T.L., 1977, Duration and volume of Columbia River Basalt volcanism, Washington, Oregon, and Idaho: Geological Society of America Abstracts with Programs, v. 9, n. 4, p. 463-464. 
Nathan, S., and Fruchter, J.S., 1974, Geochemical and paleomagnetic stratigraphy of the Picture Gorge and Yakima Basalts (Columbia River Group) in central Oregon: Geological Society of America Bulletin, v. 85, p. 63-67.

National Oceanographic and Atmospheric Administration, 1979, Local climatological data, annual summary with comparative data, Salem, Oregon, 3 p.

Norman, Elizabeth Storm, 1980, Geology of the Columbia River basalt in Silver Falls State Park, Oregon: Portland, Oregon, Portland State University, B.S. thesis, $43 \mathrm{p}$.

Norton, S.A., 1973, Laterite and bauxite formation: Economic Geology, v. 68, p. 353-361.

Parham, walter E., 1969, Formation of halloysite from feldspar: low temperature, artificial weathering vs. natural weathering: Clays and Clay Minerals, v. 17, p. $13-20$.

Patterson, S.H., 1971, Investigations of ferruginous bauxite and other mineral resources on Kauai and a reconnaissance of ferruginous bauxite deposits on Maui, Hawaii: U.S.G.S. Professional Paper 656, 74 p.

Peterson, Ulrich, 1971, Laterite and bauxite formation: Economic Geology, v. 66, p. 1070-1071.

Pourbaix, Marcel, 1966, Atlas of Electrochemical Equilibria in Aqueous Solutions: Oxford, Pergammon Press, p. 171-173 and 461-462.

Powell, L.V., 1978, The structure, stratigraphy, and correlation of the Grande Ronde Basalt on Tygh Ridge, Wasco County, Oregon: Moscow, Id., Idaho University M.S. thesis, $57 \mathrm{p}$.

Schlicker, H.G., 1977, Geologic restraints to development in selected areas of Marion County, Oregon: Oregon Department of Geology and Mineral Industries OpenFile Report 0-77-4, p. 35-37.

Schlicker, H.G., and Deacon, R.J., 1968, Engineering geology for Marion County, Oregon: a water and sewage study: Oregon Department of Geology and Mineral Industries unpublished report, 35 p. map scale 1:84,000, 4 sheets. 
Sherman, D.G., 1949, Factors influencing the development of lateritic and laterite soils in the Hawaiian Islands: Pacific Science, v. 3, p. 307-314.

Siefferman, G., and Millot, G., 1969, Equatorial and tropical weathering of recent basalts from Cameroon: allophane, halloysite, metahalloysite, kaolinite, and gibbsite: in Hell er, Lisa, ed., Proceedings of the International Clay Conference 1969, Israel Universities Press, p. 417430 .

Snavely, P.D., Jr., and Baldwin, E.M., 1948, Siletz river volcanic series, northwestern Oregon: American Association of Petroleum Geologists Bulletin, v. 32 , p. 806-812.

Snavely, P.D., Jr., and Wagner, H.C., 1963, Tertiary geologic history of western Oregon and Washington: Washington Division of Mines Report of Investigations, v. 22, 25 p.

Swanson, D.A., and Wright, T.L., 1981, Guide to geologic field trip between Lewiston, Idaho, and Kimberly, Oregon, emphasizing the Columbia River Basalt Group, in Johnston, D.A., and Donnelly-Nolan, J., eds., Geological Survey Circular 838, p. 1-14.

Swanson, D.A., Wright, T.L., Hooper, P.R., and Bentley, R.D., 1979, Revisions in stratigraphic nomenclature of the Columbia River Basalt Group: U.S.G.S. Bulletin 1457-G, $59 \mathrm{p}$.

Thayer, T.P., 1939, Geology of the Salem Hills and the North Santiam River basin, Oregon: Oregon Dept. of Geology and Mineral Industries Bulletin, n.15, 40 p.

Valeton, Ida, 1972, Bauxites: Amsterdam, Elseiver, 226 p.

waters, A.C., 1961, Stratigraphic and lithologic variations in the Columbia River basalt: American Journal of Science, v. 259, p. 583-611.

Watkins, N.D., and Baski, A.K., 1974, Magnetostratigraphy and oroclinal folding of the Columbia River, Steens, and Owyhee basalts in Oregon, Washington, and Idaho: American Journal of Science, v. 274, p. 148-189.

Watkins, N.D., Gunn, B.M., and Coy-yll, R., 1970, Major and trace element variations during the initial cooling of an Icelandic lava: American Journal of Science, v. 268 , p. $24-29$. 
Wells, F.G., and Peck, D.L., 1961, Geologic map of Oregon west of the 12lst Meridian: U.S.G.S. Miscellaneous Geologic Investigations, Map I-325.

White, A.H., 1976, Genesis of low-iron bauxites, northeastern Cape York, Queensland, Austrailia: Economic Geology, v. 71, p. 1526-1532.

Wollast, R., 1967, Kinetics of the alteration of K-feldspar in buffered solu tions at low temperature: Geochimica et Cosmochimica Acta, v. 31, p. 635-638.

Wright, T.L., Groiler, M.J., and Swanson, D.A., 1973, Chemical variation related to the stratigraphy of the Columbia River basalt: Geological Society of America Bulletin, v. 84, p. 371-386. 
MAJOR ELEMENT ANALYSES OF CRBG SAMPLES FROM THE SALEM HILLS (VALUES IN 8 )

Sample \# $\quad \mathrm{SiO}_{2} \quad \mathrm{Al}_{2} \mathrm{O}_{3} \quad \mathrm{TiO}_{2} \quad \mathrm{Fe}_{2} \mathrm{O}_{3} \quad \mathrm{FeO} \quad \mathrm{MnO} \quad \mathrm{CaO} \quad \mathrm{MgO} \quad \mathrm{K}_{2} \mathrm{O} \quad \mathrm{Na}_{2} \mathrm{O} \quad \mathrm{P}_{2} \mathrm{O}_{5}$

\section{LOW MgO CHEMICAL TYPE}

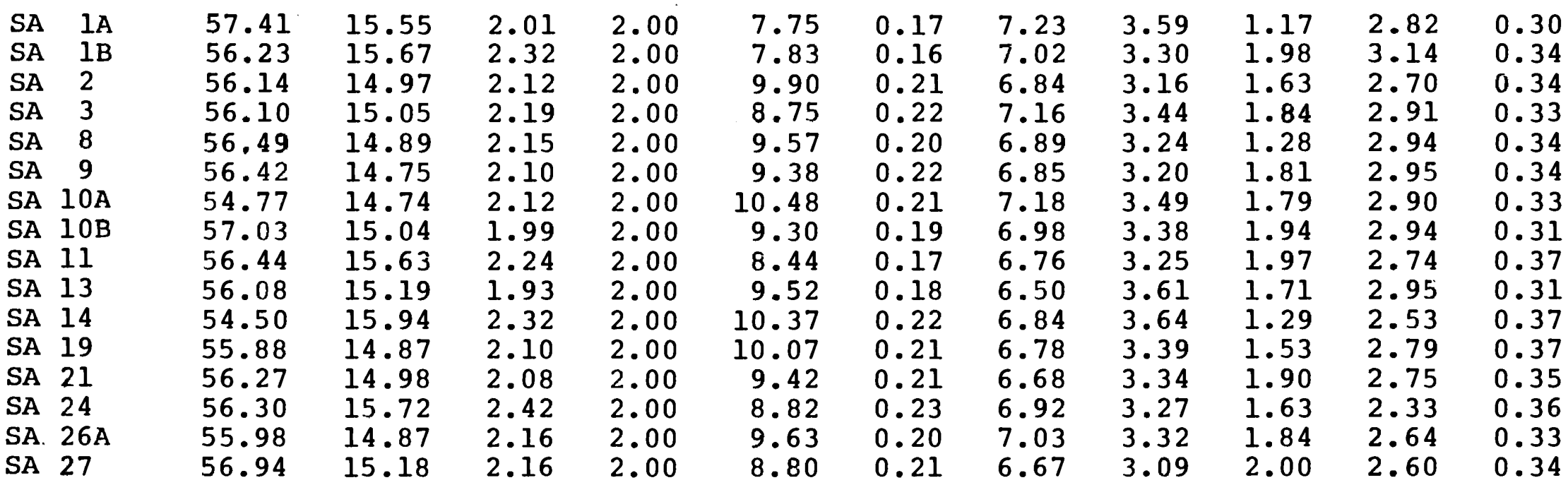

HIGH MgO CHEMICAL TYPE

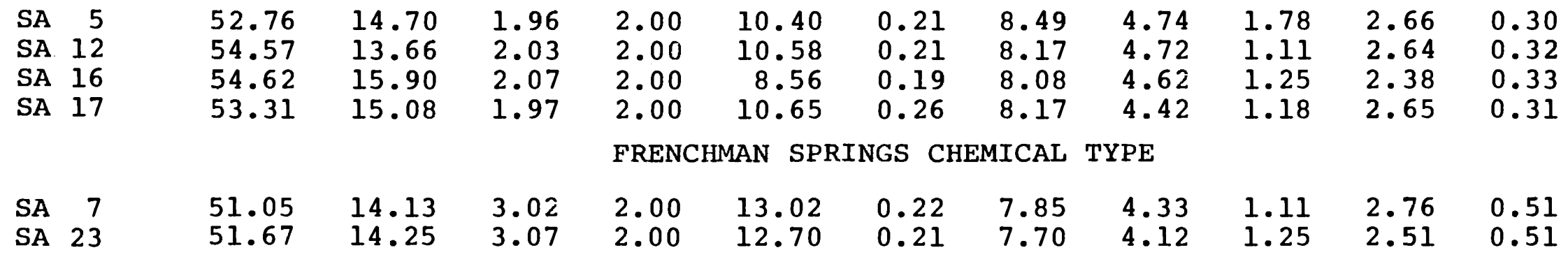




\section{APPENDIX B}

\section{INAA DATA ANALYSIS}

Clay-rich samples for geochemical analysis were first dried in a convective oven at $90^{\circ} \mathrm{C}$ for 12 - 18 hours. They were then ground in a high carbon steel mortar and pestle to less than $1 \mathrm{~mm}$ size. At this point a split of the sample was removed for $x$-ray fluoresence preparation. Rock samples were prepared similarly except that no drying was required.

Approximately one gram of sample was placed in a one dram size polyvinyl vial, two of which were placed into larger polyvinyl vials for irradiation. Irradiation was for 60 minutes at $235 \mathrm{KW}$ in the "lazy-susan" assemblage of a TRIGA Mark I nuclear reactor housed at Reed College in Portland. The thermal flux was approximately $2 \times 10^{12}$ $\mathrm{n}-\mathrm{cm}^{-2}-\mathrm{sec}^{-1}$ and the epithermal-to-thermal flux ratio was about 5.0 .

Detection was accomplished on the Portland State University Earth Science department's high resolution Ge(Li) detector which is part of a Tracor-Northern 4000 system. The samples were counted for 1000 seconds $(2500$ seconds for 
standards) about 5 - 6 days after irradiation and again for 2500 seconds (4000 - 5000 seconds for standards) at 4 - 6 weeks after irradiation. Concentration calculations were made by the comparative method utilizing peak information supplied by a Tracor-Northern 4000 routine.

The samples were part of three separate irradiation runs labeled as $7 \mathrm{C}, 7 \mathrm{D}$, and $7 \mathrm{E}$. Whenever possible, the same reference standard was used for a given photopeak determination for each run. The complete results of the three runs are given in Table III. Sample TFB 72-77 was included in runs $7 \mathrm{C}$ and $7 \mathrm{D}$, and sample TFT 1 was included in runs $7 \mathrm{C}$ and $7 \mathrm{E}$. Additional evaluation of data validity can be made from the secondary standards analyses. Tables IV and $V$ summarize the standards and duplicates results, respectively.

The errors from run to run do not follow any systematic pattern and thus are difficult to evaluate. Possible sources of error include sample splitting, reactor geometry effects, and effects related to position with respect to other samples during irradiation, e.g. a duplicate sample being closely associated with one rock type on one run and with a completely different rock type on the next run. Another and a probable source of error was discovered during a subsequent irradiation by other 
members of the Portland State University Earth Sciences department. During this run it was noticed that the large polyvinyl vials were randomly loaded into the reactor with respect to top and bottom, i.e. the workers at Reed College had not systematically placed the vials into the reactor's lazy susan. A $10 \%$ difference in flux between the top and bottom samples has been estimated by analyses of standards which are duplicated in the top and bottom of certain large vials. 
EXP 7C 1ST COUNT (TOF) HOFFMAN

SAMPLE

$0.50 \quad 60.10$ TFN

TFN 1 $8-12$

TFE1 6-17

13.30

41.20

12.70

TFB $28-32$

5.06

TFT 2

TFB 23-28
TFB 3-B

16.80
30.50

38.90

TFE $72-77$

44.80

10.50

34.10

42.40
24.50

24.50
25.40

25.40
18.20

22.70

27.60

28.10

$0.20 \quad 5.60$

$0.50 \quad 49.90$

$0.20 \quad 76.00$

$0.14 \quad 47.60$

$0.30 \quad 70.70$

$0.40 \quad 40.90$

$0.50 \quad 61.30$

61.30
68.00

$0.20 \quad 61.30$

$0.40 \quad 44.70$

$0.50 \quad 63.20$

$0.50 \quad 30.40$

$0.50 \quad 29.80$

$0.40 \quad 32.50$

$0.50 \quad 33.00$

$\begin{array}{ll}0.50 & 29.90 \\ 0.50 & 33.70\end{array}$

SA-11

25.00

$0.40 \quad 32.90$

$\begin{array}{llll}\text { ACR1 STD } & 25.00 & 0.40 & 32.90 \\ \text { ARC1 STD } & 45.80 & 0.50 & 25.60 \\ W-1 \text { STD } & 11.20 & 0.20 & 34.80\end{array}$

$\begin{array}{lrl}\text { EXP 7C } & \text { 2ND COUNT (TOP) HOFFMAN } \\ \text { SAMPLE } & \text { FE }\end{array}$

$\begin{array}{llll}\text { TFB50-52 } & 16.09 & 0.13 & 57.30\end{array}$

TFN 1

TFF16-17 16.92

$\begin{array}{ll}0.01 & 5.34 \\ 0.12 & 7.15\end{array}$

0.1471 .80

0.1563 .00

TFT 2

$\begin{array}{ll}\text { TFT } 2 & 16.62\end{array}$

$\begin{array}{ll}\text { TFB } 3-8 & 18.75 \\ \text { TFE } & 11.63\end{array}$

TFE 72-77 17.05

0.1445 .97

$0.15 \quad 67.60$

0.1459 .30

0.1565 .80

TFT 1

18.52

0.1558 .80

$0.14 \quad 43.30$

$0.14 \quad 59.90$

$0.07 \quad 26.26$

$0.07 \quad 31.33$

SA-13

SA- 8

7.63

0.07

SA- 9

SA- 5
SA- 7

SA-11

7.85

$0.07 \quad 31.13$

$0.07 \quad 31.66$

$0.06 \quad 29.97$

$\begin{array}{ll}0.06 & 29.97 \\ 0.07 & 33.65\end{array}$

$0.07 \quad 34.80$

$\begin{array}{ll}0.07 & 34.80 \\ 0.09 & 26.47 \\ 0.10 & 30.79\end{array}$
FE

SM

NA

LIJ

$0.40 \quad 16.80$

$0.09 \quad 0.70$

$\begin{array}{ll}0.09 & 14.90 \\ 0.50 & 17.50\end{array}$

$0.40 \quad 17.10$

$0.50 \quad 19.40$

$\begin{array}{ll}.30 & 12.50\end{array}$

$0.40 \quad 17.40$

0.50

19.00

$0.40 \quad 19.20$

$0.40 \quad 17.80$

$0.40 \quad 17.50$

\begin{tabular}{ll}
$0.30 \quad 7.90$ \\
\hline
\end{tabular}

$0.30 \quad 7.60$

0.30

0.30
0.30

0.30

7.90
10.30

6.62

6.40

$0.30 \quad 9.60$

$\begin{array}{ll}0.20 & 9.00 \\ 0.20 & 7.50\end{array}$

$0.30 \quad 8.36 \quad 0.09$

$\begin{array}{lll}0.04 & 0.63 & 0.01\end{array}$

$0.30 \quad 7.17$

$0.30 \quad 2.80$

0.40

16.62

$0.30 \quad 1.76$

$\begin{array}{ll}0.40 & 3.33 \\ 0.30 & 5.57\end{array}$

$0.30 \quad 10.56$

0.40

10.56
9.70

$0.40 \quad 2.54$

$0.40 \quad 6.79$

$0.30 \quad 14.75$

$0.20 \quad 6.36$

$0.20 \quad 6.79$

$0.20 \quad 5.56$

$0.30 \quad 7.18$

$\begin{array}{ll}0.19 & 7.05 \\ 0.20 & 7.59\end{array}$

0.207 .46

$\begin{array}{rrr}0.20 & 10.35 & 0.15 \\ 0.18 & 3.60 & 0.05\end{array}$

CE

$0.20 \quad 7.70$

$\begin{array}{ll}0.04 & 7.20 \\ 0.17 & 9.30\end{array}$

$0.30 \quad 7.60$

$0.20 \quad 7.80$

\section{$0.17 \quad 7.10$}

$0.20 \quad 8.50$

$0.14 \quad 7.80$

$0.20 \quad 8.00$

$0.20 \quad 7.40$

0.20

0.1

7.40
7.40

7.20
4.10

4.10
4.80

$0.12 \quad 4.50$

$0.13 \quad 3.48$

$\begin{array}{ll}0.12 & 4.20 \\ 0.11 & 4.12\end{array}$

$\begin{array}{ll}0.11 & 4.12 \\ 0.14 & 5.00\end{array}$

$0.15 \quad 2.51$

$\begin{array}{ll}0.15 & 9.51 \\ 0.11 & 9.80 \\ 0.15 & 4.50\end{array}$

0.

0.30

0.20
0.32

55.30

$\begin{array}{rr}0.30 & 25.60 \\ 0.30 & 189.00\end{array}$

$0.30 \quad 35.70$

$0.30 \quad 38.70$

0.30

0.30

32.40

0.20

42.40
48.90

$0.20 \quad 45.20$

0.18

$0.18 \quad 33.30$

$0.19 \quad 38.10$

0.2050 .30

0.1920 .00

$\begin{array}{ll}0.30 & 88.00 \\ 0.30 & 47.00\end{array}$
$0.30 \quad 62.50$
0.04

0.17

0.03

0.04

0.11

0.11

0.04

0.16

0.09

0.10

0.10

0.08
0.10

0.10

0.11

0.11

0.020

0.010.

0.020.

$\begin{array}{ll}0.01 & 0 \\ 0.02 & 0\end{array}$

0.02

0.01

0.02

0.01

0.02

0.02

2.42

2.29

2.06

2.06

2.35

2.60

2.35
1.68$$
1.90
$$

1.90

0.70

1.60
4.00

1.70

1.90
1.90

1.60
2.00

1.70

1.70

2.00
1.40

1.50

1.40

1.30
1.50

2.00

1.60

1.50

2.00
3.00

TH$$
0 .
$$

7.70
8.00

11.30

7.40
7.50

7.50

8.40
9.60

7.50

8.20

7.70

5.70

6.30

4.90
5.60

5.90

2.80
3.70

3.70
5.30

6.10

2.20

6. 80

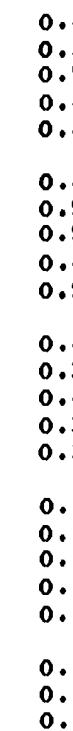

0.40
0.30

0.50

0.40
0.40

40.00

$0.50 \quad 53.00$

0.5070 .00

$\begin{array}{ll}0.40 & 53.00 \\ 0.50 & 44.00\end{array}$

$0.40 \quad 27.00$

.40
0.30

0.300

$0.20 \quad 29.55$

$0.30 \quad 15.34$

0.30 
Table III (cont'd)

FXP 70 15T COUNT HOFFHAN SAMFIE

$\begin{array}{lr}0.40 & 66.30 \\ 0.40 & 89.30 \\ 1.10 & 82.00 \\ 0.60 & 92.40 \\ 0.30 & 114.70 \\ & \\ 0.80 & 75.90 \\ 0.60 & 63.30 \\ 0.30 & 55.70 \\ 0.40 & 70.90 \\ 0.15 & 53.40 \\ 0.30 & 51.20 \\ 0.40 & 48.50 \\ 0.30 & 50.60 \\ 0.40 & 50.50 \\ 0.40 & 61.10 \\ 0.70 & 61.70 \\ 0.10 & 34.36 \\ 0.18 & 27.60 \\ 0.40 & 0.18 \\ 0.18 & 34.40 \\ 0.50 & 28.69\end{array}$

$0.50 \quad 21.60$

$0.50 \quad 20.40$

$0.50 \quad 21.10$

0.60

$0.40 \quad 15.80$

$0.40 \quad 15.00$

$0.40 \quad 10.90$

$\begin{array}{ll}0.50 & 17.20 \\ 0.30 & 16.90\end{array}$

$0.30 \quad 14.88$

$0.30 \quad 14.20$

$\begin{array}{ll}0.30 & 14.70 \\ 0.30 & 14.20\end{array}$

$\begin{array}{ll}0.30 & 14.20 \\ 0.40 & 17.50\end{array}$

$0.40 \quad 18.20$

0.19

0.20

0.20

9.82

7.50
9.97
FE

0.

$0.20 \quad 0.55$

$0.30 \quad 6.69$

$0.30 \quad 14.29$

0.30

$0.20 \quad 14.59$

0.20

0.16

0.30

6.91

2.63
4.79

0.195 .49

$\begin{array}{ll}0.19 & 5.49 \\ 0.20 & 5.85\end{array}$

0.20

0.20

5.85

5.04
9.64

9.64
10.49

0.3016 .06

0.14

3.63
11.48
$0.12 \quad 3.60$
EXP 7D 2ND COUNT HOFFMAN

SAHPLE FE

SC

$\begin{array}{llll}\text { PHB } 2-3 & 15.22 & 0.09 & 66.77\end{array}$

PHA 3- 6. 20.93 $0.11 \quad 87.90$

PHP 7- 19.660 .10

$\begin{array}{llll}\text { PHF 8-13 20.54 } & 0.10 & 90.20\end{array}$

$\begin{array}{llll}\text { PHB13-15 } 23.73 & 0.12 & 112.00\end{array}$

FHB15-17 15.47

PHB20-22 14.35

PHH25-27 10.63

PHA31-32 17.26

FHB42-43 16.42

EFT $1 \quad 14.29$

EFT 2 14.28

$\begin{array}{ll}\text { EFT } 3 & 14.94 \\ \text { EFT } 4 & 14.16\end{array}$

TFB72-77 17.10

0.12112 .00

0.0975 .10

$\begin{array}{ll}0.08 & 59.87 \\ 0.07 & 54.45\end{array}$

$0.07 \quad 54.45$

$0.09 \quad 51.86$

$0.08 \quad 49.84$

$0.08 \quad 48.36$

$0.08 \quad 50.19$

$0.08 \quad 50.10$

0.1059 .67

$0.09 \quad 61.47$

$\begin{array}{ll}0.04 & 34.80 \\ 0.06 & 28.55\end{array}$

$\begin{array}{ll}\text { W STI } & 7.50\end{array}$

ARC 1 ST 10.06

28.55
HF

0.19

0.20

0.18

0.30

0.20

0.17

0.20

0.14

0.147 .20

$\begin{array}{ll}0.14 & 7.30 \\ 0.14 & 6.90\end{array}$

$0.17 \quad 7.10$

0.176 .30

$\begin{array}{ll}0.10 & 2.09 \\ 0.08 & 9.80\end{array}$
M

0.01
0.06
0.20

0.20

0.10

0.05

0.11

0.03

0.05

0.03

0.05

0.05
0.05

0.08

0.06

0.12

0.04
0.13

0.13
0.03

0.08
NA $0.08 \quad 0$ 0.210 .04 $\begin{array}{llll}0.01 & 0 . & 0.28 & 0.04 \\ 0.01 & 0 . & 0.21 & 0.04\end{array}$ $\begin{array}{llll}0.01 & 0 . & 0.18 & 0.04\end{array}$

$\begin{array}{llll}0.01 & 0 . & 0.15 & 0.04\end{array}$ $\begin{array}{llll}0.01 & 0 . & 0.19 & 0.04\end{array}$ 0.03 0. 0.000 .0 $\begin{array}{llll}0.02 & 0 . & 0.15 & 0.03 \\ 0.01 & 0 . & 0.0 & 0.0\end{array}$

$\begin{array}{llll}0.04 & 0.00 & 0.23 & 0.03\end{array}$

$0.05 \quad 0.0 .000 .03$

0.040 .0 .040 .03

0.050 .0040 .31

$\begin{array}{llll}0.05 & 0 . & 0.38 & 0.04 \\ 0.02 & 0 . & 0.47 & 0.04\end{array}$

$\begin{array}{llll}0.02 & 0 . & 0.24 & 0.04\end{array}$ $\begin{array}{llll}1.67 & 0.01 & 0.21 & 0.03\end{array}$ $2.56 \quad 0.01 \quad 0.41 \quad 0.04$ $\begin{array}{llll}1.68 & 0.01 & 0.22 & 0.02 \\ 2.62 & 0.01 & 0.44 & 0.03\end{array}$

$\begin{array}{rr}0.20 & 67.00 \\ 0.30 & 69.30 \\ 0.20 & 266.00 \\ 0.30 & 166.00 \\ 0.30 & 53.70 \\ 0.30 & 164.00 \\ 0.20 & 82.90 \\ 0.20 & 14.30 \\ 0.30 & 68.50 \\ 0.20 & 39.50 \\ 0.20 & 75.60 \\ 0.20 & 76.90 \\ 0.20 & 64.90 \\ 0.20 & 100.20 \\ 0.20 & 65.80 \\ 0.20 & 119.00 \\ 0.11 & 14.00 \\ 0.19 & 88.00\end{array}$

TH

1.60
1.60
3.00
3.00
1.90
3.00
1.80
1.40
1.80
1.40
1.60
1.60
1.60
1.80
1.60
2.00
2.00
1.40

B.30

8.00

7.10
7.70

B.50

Q. 20

6.80

7.60

8. 30

6.00

8.50

9.00

9.00
8.90

8.90
6.90

6.50

1.80
6.80
CR
0.30

$0.30 \quad 37.00$

$0.30 \quad 33.00$

$0.30 \quad 46.00$

0.3036 .00

$0.30 \quad 25.00$

$0.30 \quad 26.00$

$0.30 \quad 41.00$

$0.30 \quad 99.00$

$0.30 \quad 69.00$

$0.30 \quad 76.00$
$0.30 \quad 71.00$

$\begin{array}{ll}0.30 & 70.00 \\ 0.20 & 48.00\end{array}$

$0.20 \quad 36.00$

$\begin{array}{lc}0.20 & 36.00 \\ 0.11 & 114.00 \\ 0.19 & 0 .\end{array}$
1.60

3.00
3.00

3.00
3.00

3.00

3.00

2.00
3.00

3.00

3.00

3.00

3.00
3.00

$3.00 \quad 36.00$

$3.00 \quad 31.90$

$3.00 \quad 63.40$

$2.00 \quad 46.00$

2. co

$23.70 \quad 0.40$ 0.50
2.40 $37.90 \quad 0.50$ 0.70

$1.40 \quad 0.60$
.400 0.60
.80 $2.40 \quad 0.60$

0.50 0.50 0.50

0.50
0.70

0.70

0.50
0.40 
Table III (cont'd)

EXP TE $15 T$ COUNT HOFFHAN SAMPLE

$\begin{array}{lll}\text { RHC } & 2-5 & 25.10 \\ \text { RHC } 5-7 & 51.30\end{array}$

RHC10-12 $122.00 \quad 0.60$

$\begin{array}{lll}52.00 & 1.20 \quad 77.50\end{array}$

$\begin{array}{llll}\text { RHC13-15 } & 54.60 & 0.60 & 50.60 \\ \text { RHC16-17 } & 27.20 & 0.40 & 41.70\end{array}$

$\begin{array}{llll}\text { RHC 19-20 } & 67.10 & 0.70 & 45.20\end{array}$

$\begin{array}{llll}\text { RHC 20-25 } & 10.37 & 0.18 & 36.40\end{array}$

$\begin{array}{llll}\text { RHC25-30 } & 7.18 & 0.15 & 45.90 \\ \text { RH30-31C } & 9.50 & 0.19 & 60.40 \\ \text { RHC 31-35 } & 2.63 & 0.08 & 52.00\end{array}$

RHC 40-45 $\quad 97.30$

TFT $7 \quad 4.69$

TFE72-77 $32.00 \quad 0.40 \quad 50.60$

9.19

$0-16$ 5TD 38.60

G-2 STR $91.50 \quad 1.10 \quad 3.68$

$45.80 \quad 0.60 \quad 26.90$

H-1 STR 10.90

$0.60 \quad 26.90$

EXP 7E 15T COUNT HOFFMAN

sc

$\begin{array}{llll}\text { RH3O-31A } & 25.50 & 0.70 & 33.00 \\ \text { RH30-31R } & 23.70 & 0.60 & 32.40 \\ \text { SA- 7 } & 24.40 & 0.70 & 33.00 \\ \text { SA-23 } & 22.10 & 0.70 & 30.60 \\ \text { SA-12 } & 19.60 & 0.60 & 32.60 \\ & & & \\ \text { SA-17 } & 18.50 & 0.60 & 30.70 \\ \text { SA-2AB } & 26.00 & 0.70 & 31.10 \\ \text { SA-10B } & 22.30 & 0.70 & 27.50 \\ \text { ARC1 STD } & 45.40 & 0.80 & 36.50 \\ W-1 \text { STI } & 11.10 & 0.40 & 34.40\end{array}$

$F$

$0.30 \quad 15.10$

$0.40 \quad 13.50$

9.37

$0.30 \quad 13.40$

$0.40 \quad 23.50$

$0.19 \quad 9.35$

0.30

0.40

0.06

0.14

0.20

0.20

17.30

1.87
9.70

9.70
7.50
$0.30 \quad 17.30$

$0.40 \quad 14.50$
0.20

0.30
0.50

0.50

0.30
0.30

0.30

0.20

0.30

0.40
0.40

0.20

0.20
0.12

0.16

0.30

0.30

0.14

$0.14 \quad 6.4$

4.58
1.17

11.01

11.01
1.64
8.89

$0.20 \quad 11.15$
SH

FE

$\begin{array}{rr}0.50 & 9.60 \\ 0.50 & 11.30 \\ 0.50 & 10.50\end{array}$

$0.50 \quad 10.50$

$\begin{array}{ll}0.50 & 9.40 \\ 0.50 & 9.50\end{array}$

0.50

0.50
0.50

0.50

0.40
0.40

\subsection{10}

7.60

9.40

0.40
0.40
0.50
0.40
0.40
0.40
0.40
0.40
0.00

$\begin{array}{ll}4.98 & 0.04 \\ 8.54 & 0.07\end{array}$

$\begin{array}{rr}8.54 & 0.07 \\ 26.37 & 0.19\end{array}$

26.370 .19

$\begin{array}{ll}4.24 & 0.04\end{array}$

12.66

1.42
2.63

8.89
2.23

6.41

11.15
3.60

NA

0.1

0.02

0 .

0.01

0.10

0.02
0.02

0.05

0.02

0.01

0.

0.01

0.09

0 .

0.08

$0.02 \quad 0.01$

0.01

0.07

0.01

0.06

0.07

0.09

3.26
3.22

$2.4 \mathrm{~B}$

SH

7.32
7.04

0.13

$\begin{array}{lll}0.13 & 1.66 & 0.01\end{array}$

$\begin{array}{rrrr}7.43 & 0.14 & 2.12 & 0.01 \\ 6.57 & 0.12 & 1.94 & 0.01\end{array}$

$\begin{array}{llll}6.57 & 0.12 & 1.94 & 0.01\end{array}$

5.28

6.39

ธ.ค.

0.10

0.12

0.12
$2.01 \quad 0.01$

$2.46 \quad 0.01$ $\begin{array}{ll}0.01 \\ .40 & 0.01\end{array}$ $\begin{array}{rrrrr}0.40 & 10.77 & 0.17 & 7.40 & 0.01 \\ 0.30 & 3.60 & 0.07 & 1.68 & 0.01\end{array}$

$\begin{array}{rrrrr}0.40 & 10.77 & 0.17 & 7.40 & 0.01 \\ 0.30 & 3.60 & 0.07 & 1.68 & 0.01\end{array}$

LU

$0.16 \quad 0.03$

0.150 .03

0.210 .04

$0.16 \quad 0.03$

0.22

0.090 .02

$0.18 \quad 0.03$

$0.27 \quad 0.04$

0.110 .02 o. 0 .

$0.14 \quad 0.02$

0.120 .03

0.390 .04

0 . 0 .

$0.46 \quad 0.05$

$\begin{array}{ll}0.44 & 0.05 \\ 0.21 & 0.03\end{array}$
0.0 
Table III (cont'd)

FXP 7E 2NII COUNT HOFFMAN SAMPLE

\begin{tabular}{|c|c|c|c|c|c|}
\hline $\begin{array}{l}R H C 2-5 \\
R H C, 5-7 \\
R H C 10-12\end{array}$ & $\begin{array}{r}9.05 \\
15.76 \\
23.14\end{array}$ & $\begin{array}{l}0.06 \\
0.09 \\
0.13\end{array}$ & $\begin{array}{l}27.13 \\
38.25 \\
72.30\end{array}$ & $\begin{array}{l}0.08 \\
0.11 \\
0.20\end{array}$ & $\begin{array}{r}7.66 \\
11.70 \\
11.70\end{array}$ \\
\hline $\begin{array}{l}\text { RHC 13-15 } \\
\text { RHC16-17 }\end{array}$ & $\begin{array}{l}16.81 \\
14.09\end{array}$ & $\begin{array}{l}0.10 \\
0.09\end{array}$ & $\begin{array}{l}46.90 \\
39.36\end{array}$ & $\begin{array}{l}0.13 \\
0.11\end{array}$ & $\begin{array}{l}9.60 \\
8.90\end{array}$ \\
\hline $\begin{array}{l}R H C 19-20 \\
R H C 20-25 \\
R H C 25-30\end{array}$ & $\begin{array}{r}12.41 \\
8.76 \\
12.21\end{array}$ & $\begin{array}{l}0.08 \\
0.06 \\
0.08\end{array}$ & $\begin{array}{l}42.01 \\
34.12 \\
42.44\end{array}$ & $\begin{array}{l}0.12 \\
0.10 \\
0.12\end{array}$ & $\begin{array}{l}7.80 \\
6.06 \\
6.39\end{array}$ \\
\hline $\begin{array}{l}\text { RH30-31A } \\
\text { RH30-31B }\end{array}$ & $\begin{array}{l}9.37 \\
8.75\end{array}$ & $\begin{array}{l}0.06 \\
0.06\end{array}$ & $\begin{array}{l}31.99 \\
30.14\end{array}$ & $\begin{array}{l}0.09 \\
0.09\end{array}$ & $\begin{array}{l}4.16 \\
3.87\end{array}$ \\
\hline $\begin{array}{l}\text { RH30-31C } \\
\text { RHC 31-35 } \\
\text { RHC } 40-45\end{array}$ & $\begin{array}{r}21.25 \\
19.76 \\
8.39\end{array}$ & $\begin{array}{l}0.12 \\
0.12 \\
0.05\end{array}$ & $\begin{array}{l}55.08 \\
47.10 \\
18.34\end{array}$ & $\begin{array}{l}0.16 \\
0.1 .3 \\
0.05\end{array}$ & $\begin{array}{l}8.20 \\
4.42 \\
3.52\end{array}$ \\
\hline $\begin{array}{l}\text { TFT } 7 \\
\text { PHN } 1\end{array}$ & $\begin{array}{l}4.54 \\
6.86\end{array}$ & $\begin{array}{l}0.04 \\
0.05\end{array}$ & $\begin{array}{l}33.64 \\
39.62\end{array}$ & $\begin{array}{l}0.09 \\
0.11\end{array}$ & $\begin{array}{l}7.70 \\
7.80\end{array}$ \\
\hline $\begin{array}{l}\text { TFB72-77 } \\
\text { TFT } 1 \\
\text { SA- } 7\end{array}$ & $\begin{array}{r}13.30 \\
15.80 \\
9.52\end{array}$ & $\begin{array}{l}0.08 \\
0.10 \\
0.07\end{array}$ & $\begin{array}{l}46.55 \\
49.97 \\
31.40\end{array}$ & $\begin{array}{l}0.13 \\
0.14 \\
0.09\end{array}$ & $\begin{array}{l}6.30 \\
6.40 \\
3.85\end{array}$ \\
\hline $\begin{array}{l}5 A-23 \\
S A-12\end{array}$ & $\begin{array}{l}8.61 \\
7.66\end{array}$ & $\begin{array}{l}0.06 \\
0.05\end{array}$ & $\begin{array}{l}28.08 \\
30.40\end{array}$ & $\begin{array}{l}0.08 \\
0.09\end{array}$ & $\begin{array}{l}3.46 \\
3.30\end{array}$ \\
\hline $\begin{array}{l}S A-17 \\
5 A-26 B \\
5 A-10 B\end{array}$ & $\begin{array}{l}6.94 \\
7.82 \\
7.06\end{array}$ & $\begin{array}{l}0.05 \\
0.05 \\
0.05\end{array}$ & $\begin{array}{l}27.44 \\
29.59 \\
25.69\end{array}$ & $\begin{array}{l}0.08 \\
0.08 \\
0.07\end{array}$ & $\begin{array}{l}2.95 \\
3.93 \\
3.54\end{array}$ \\
\hline $\begin{array}{l}0-16 \text { GTD } \\
0-2 \text { 5TD }\end{array}$ & $\begin{array}{l}1.08 \\
1.74\end{array}$ & $\begin{array}{l}0.02 \\
0.03\end{array}$ & $\begin{array}{l}3.48 \\
3.24\end{array}$ & $\begin{array}{l}0.03 \\
0.03\end{array}$ & $\begin{array}{l}6.59 \\
7.49\end{array}$ \\
\hline $\begin{array}{l}\text { ARC1 STD } \\
W-1 \text { STD }\end{array}$ & $\begin{array}{l}9.12 \\
7.50\end{array}$ & $\begin{array}{l}0.06 \\
0.05\end{array}$ & $\begin{array}{l}25.57 \\
34.80\end{array}$ & $\begin{array}{l}0.07 \\
0.10\end{array}$ & $\begin{array}{l}9.80 \\
2.21\end{array}$ \\
\hline
\end{tabular}

CE

$0.19 \quad 58.00$ $\begin{array}{ll}0.19 & 58.00 \\ 0.30 \quad 73.90\end{array}$ 0.30128 .00 $0.30 \quad 70.50$ $0.20 \quad 77.90$

$0.20 \quad 99.30$ $0.18 \quad 16.40$ $0.16 \quad 47.90$ 0.1544 .10

$0.30 \quad 19.70$ $0.19 \quad 18.00$ $0.13 \quad 95.50$ $\begin{array}{rr}0.20 & 13.60 \\ 0.20 & 132.50\end{array}$

$0.20 \quad 58.10$ $0.20 \quad 31.60$ $0.17 \quad 45.80$ $0.15 \quad 41.00$

\section{$0.13 \quad 31.00$} $\begin{array}{ll}0.13 & 31.00 \\ 0.15 & 46.50\end{array}$ 0.1539 .50 $0.20 \quad 156.00$ $\begin{array}{ll}0.20 & 89.00 \\ 0.13 & 23.10\end{array}$
$1.20 \quad 10.00$ $1.50 \quad 15.10$ $\begin{array}{rr}1.50 & 0.90\end{array}$ $1.60 \quad 8.70$

1.80 0.90 1.10 1.10
1.10

1.40 $1.10 \quad 4.01$ $1.50 \quad 2.84$ $\begin{array}{ll}0.90 & 4.57 \\ 1.90 & 7.40\end{array}$

\section{$1.50 \quad 5.80$} $1.30 \quad 6.00$ $1.20 \quad 3.29$ $\begin{array}{ll}1.10 & 3.16 \\ 1.00 & 2.73\end{array}$

$0.90 \quad 2.51$ $\begin{array}{ll}1.10 & 4.88\end{array}$ $1.30 \quad 9.50$ $2.00 \quad 23.70$

$1.50 \quad 6.80$
TH $0.30 \quad 94.00$ $0.40 \quad 93.00$ $0.30 \quad 25.90$ 25.90 16.90 $0.30 \quad 19.50$ 0.19
0.20 $0.15 \quad 15.80$ 0.1515 .80 0.15

$0.30 \quad 48.00$ 0.1929 .00 $0.13 \quad 0.90$ $\begin{array}{ll}0.18 & 28.10 \\ 0.20 & 21.80\end{array}$

$0.20 \quad 39.00$ $0.20 \quad 22.00$ $0.17 \quad 16.10$ $\begin{array}{ll}0.15 & 14.50 \\ 0.14 & 28.00\end{array}$

\subsection{5 .10} $\begin{array}{ll}0.13 & 25.10 \\ 0.18 & 10.40\end{array}$ $0.30 \quad 0$. $0.30 \quad 0.40$

0.49

$\begin{array}{ll}0.20 & 0 . \\ 0.14 & 114.00\end{array}$
CR

$\begin{array}{lll}2.00 & 17.00 \quad 0.30\end{array}$ $\begin{array}{lll}3.00 & 10.70 & 0.30\end{array}$ $2.00 \quad 29.80-0.50$ $\begin{array}{lll}1.00 & 29.80 & 0.50\end{array}$

$2.00 \quad 69.40 \quad 0.80$ $1.70 \quad 20.50 \quad 0.40$ $1.50 \quad 40.40 \quad 0.50$ $\begin{array}{lll}1.50 & 40.40 & 0.50\end{array}$

$2.0024 .20 \quad 0.40$ $2.00 \quad 46.70$ $1.20 \quad 16.80$ $1.80 \quad 59.20=0.70$ $1.80 \quad 59.20 \quad 0.70$ $\begin{array}{lll}2.00 & 55.40 & 0.70\end{array}$ $\begin{array}{lll}2.00 & 55.40 & 0.70 \\ 2.00 & 49.30 & 0.70\end{array}$ $\begin{array}{lll}1.70 & 43.10 & 0.60 \\ 1.50 & 37.10 & 0.50\end{array}$ $1.60 \quad 40.80 \quad 0.50$

$1.50 \quad 32.80 \quad 0.40$ $\begin{array}{lll}1.50 & 36.20 & 0.50\end{array}$ $0.60 \quad 41.20 \quad 0.60$ $\begin{array}{lll}0.9 & 0.74 & 0.09 \\ 0.99 & 4.60 & 0.18\end{array}$ $\begin{array}{lll}0 . & 29.30 & 0.40 \\ 2.74 & 46.00 & 0.60\end{array}$ 


\section{TABLE IV}

\section{INAA STANDARDS ANALYSES}

$7 C$

\begin{tabular}{|c|c|c|c|c|c|c|c|c|c|}
\hline & & & & & & & & & \\
\hline & $w-1$ & ARHCO-1 & w-1 & ARHCO-1 & W-1 & ARHCO-1 & 1 & 2 & tave \\
\hline $\mathrm{Fe}(1)$ & $7.50 \pm 0.18$ & $9.00 \pm 0.20$ & $7.50 \pm 0.12$ & $9.97 \pm 0.15$ & $7.50 \pm 0.18$ & $9.80 \pm 0.20$ & $7.5 \pm 0.3$ & 7.76 & $9.83 \pm 0.15$ \\
\hline $\mathrm{Fe}(2)$ & $7.50 \pm 0.07$ & $9.45 \pm 0.09$ & $7.50 \pm 0.04$ & $10.12 \pm 0.06$ & $7.50 \pm 0.05$ & $9.12 \pm 0.06$ & $7.5 \pm 0.3$ & 7.76 & $9.83 \pm 0.15$ \\
\hline $\mathbf{L a}$ & $11.20 \pm 0.20$ & $45.80 \pm 0.50$ & $10.54 \pm 0.18$ & $45.80 \pm 0.50$ & $4.00 \pm 0.20$ & $45.80 \pm 0.60$ & $12.0 \pm 2.0$ & 9.80 & $46.00 \pm 1.50$ \\
\hline $\mathbf{S m}$ & $3.60 \pm 0.05$ & $10.35 \pm 0.15$ & $3.60 \pm 0.03$ & $11.64 \pm 0.04$ & $3.60 \pm 0.04$ & $11.15 \pm 0.09$ & $2.8 \pm 0.2$ & 3.60 & $10.10 \pm 0.20$ \\
\hline Sc (1) & $34.80 \pm 0.20$ & $25.60 \pm 0.20$ & $34.80 \pm 0.20$ & $28.69 \pm 0.18$ & $34.80 \pm 0.20$ & $26.90 \pm 0.20$ & $34.8 \pm 0.8$ & 35.10 & $26.30 \pm 0.20$ \\
\hline $\operatorname{Sc}(2)$ & $34.80 \pm 0.15$ & $26.47 \pm 0.11$ & $34.80 \pm 0.10$ & $28.55 \pm 0.08$ & $34.80 \pm 0.10$ & $25.57 \pm 0.07$ & $34.8 \pm 0.8$ & 35.10 & $26.30 \pm 0.20$ \\
\hline Th & $2.20 \pm 0.30$ & $6.80 \pm 0.40$ & $1.88 \pm 0.11$ & $6.80 \pm 0.19$ & $2.20 \pm 0.14$ & $6.80 \pm 0.20$ & $2.6 \pm 0.2$ & 2.42 & $6.80 \pm 0.30$ \\
\hline Co & $46.00 \pm 0.80$ & $30.20 \pm 0.60$ & $46.00 \pm 0.50$ & $32.00 \pm 0.40$ & $46.00 \pm 0.60$ & $29.30 \pm 0.40$ & $46.0 \pm 2.0$ & 47.00 & $27.80 \pm 0.40$ \\
\hline Cr & $114.00 \pm 4.68$ & nd & $114.00 \pm 2.00$ & nd & $114.00 \pm 2.74$ & nd & $99.0 \pm 5.0$ & 114.00 & nd \\
\hline $\mathbf{H F}$ & $2.51 \pm 0.19$ & $9.80 \pm 0.30$ & $2.09 \pm 0.11$ & $9.80 \pm 0.19$ & $2.21 \pm 0.13$ & $9.80 \pm 0.20$ & $3.0 \pm 0.2$ & 2.67 & $9.80 \pm 0.20$ \\
\hline & $20.00 \pm 1.50$ & $88.00 \pm 2.00$ & $14.00 \pm 2.00$ & $88.00 \pm 1.40$ & $23.10 \pm 0.90$ & $88.00 \pm 1.50$ & $21.0 \pm 2.0$ & 23.00 & $88.00 \pm 0.50$ \\
\hline
\end{tabular}

$1_{\text {ARHCO-1 values from Additon and Seil, } 1979}$

W-1 values from 1) Gordon and others, 1968 and 2) Flannigan, 1973

( ) First count or second count value

nd not detected

values in PPM except Fe which is in 8 


\section{TABLE V}

INAA DUPLICATE SAMPLES

TFB $72-77$

7D

$7 E$

$\mathrm{FE}(1) \quad 17.4 \pm 0.3 \quad 17.5 \pm 0.2 \quad 14.7 \pm 0.3$

FE (2)

LA

SM

$\mathrm{sc}(1)$

$\mathrm{SC}(2)$

$\mathrm{TH}$

co

CR

$\mathrm{HF}$

CE

$17.1 \pm 0.1$

$17.1 \pm 0.1$

$13.3 \pm 0.1$

\begin{abstract}
$38.8 \pm 0$.
\end{abstract}
$10.6+0.110 .5 \pm 0.1$

$32.3 \pm 0.4$

$8.4 \pm 0$.

$61.3 \pm 0.461 .1 \pm 0.4$

$51.0 \pm 0.4$

$59.3 \pm 0.259 .7 \pm 0.2$

$7.5 \pm 0.46 .9 \pm 0.2$

$46.6 \pm 0.1$

$63.7 \pm 1$.

$47.1 \pm 0.5$

$5.8 \pm 0.2$

$53.0 \pm 4$.

$48.0 \pm 3.0$

$55.4 \pm 0.7$

$39.0 \pm 2.0$

$8.0 \pm 0.37 .1 \pm 0.2$
$18.5 \pm 0.215 .8 \pm 0.1$

$9.3 \pm 0.2$

$68.0 \pm 2.065 .8 \pm 1.6$

( ) first count or second count value

values in PPM except Fe which is in $\%$
TFB $28-32$

7D

$18.3 \pm 0.418 .2 \pm 0.3 \quad 19.2 \pm 0.4 \quad 17.6 \pm 0.3$

$18.1 \pm 0.2$

$17.9 \pm 0.1$

$76.5 \pm 0$.

$16.6 \pm 0.2$

$70.0 \pm 0$.

$16.7 \pm 0.1$

$10.5 \pm 0.2$

$64.5 \pm 0.5$

$61.7 \pm 0.4$

$2.5 \pm 0.1$

$2.2 \pm 0.1$

$63.0 \pm 0$.

$61.5 \pm 0$.

$7.5 \pm 0.4$

$6.5 \pm 0.2$

$61.3 \pm 0.4$

$55.0 \pm 0.4$

$57.6 \pm 0.9$

$63.4 \pm 0$.

$40.0 \pm 3.0$

$36.0 \pm 3.0$

$6.3 \pm 0.27 .8 \pm 0.3$

$6.3 \pm 0$.

TFT 1

$7 \mathrm{E}$

$58.8 \pm 0.250 .0 \pm 0.1$

$7.7 \pm 0.46 .0 \pm 0.2$

$53.4 \pm 0.849 .3 \pm 0.7$

$27.0 \pm 3.022 .0 \pm 2.0$

$58.1 \pm 1.5189 .0 \pm 4.0119 .0 \pm 2.032 .4 \pm 1.731 .6 \pm 1.3$ 


\section{APPENDIX C}

\section{X-RAY FLUORESENCE DATA ANALYSIS}

$\mathrm{X}$-ray fluoresence analyses were made at the oregon Graduate Center, Beaverton, Oregon. Samples were prepared by the author. After drying, grinding to less than $1 \mathrm{~mm}$, and splitting as described in Appendix B, the samples were ground in an aluminum oxide disk micropulverizer. The pulverized samples were then diluted to $97-98 \%$ with reagent grade boric acid $\left(\mathrm{H}_{3} \mathrm{BO}_{3}\right)$ and pressed at $7000-9000$ psi into pellets with a boric acid shell.

Two analyzed standards, VL-1, a Venezuelan ferruginous bauxite, and NSB 69, a bauxite, were prepared in a similar manner. Reference concentrations for the two standards are given in Table VI. Additional $\mathrm{Al}_{2} \mathrm{O}_{3}$ and MnO values for XRF reference were determined for 12 samples by atomic absorption spectrophotometry (AAS). These were intended to be primary reference values for XRF, but the bauxite standards became available shortly before the XRF analyses were made. Thus both sets of standards were available. 
TABLE VI

REFERENCE VALUES FOR BAUXITE STANDARDS
$\mathrm{Al}_{2} \mathrm{O}$
$\mathrm{Fe}_{2} \mathrm{O}_{3}$
$\mathrm{SiO}_{2}$
$\mathrm{TiO}_{2}$
MnO

$V L-1 \quad 37.38$

35.83

1.21

3.15

NSB $-69 \quad 55.06$

5.66

6.30

3.07

0.55

Four XRF runs of 9 unknowns and 3 standards each were made. The peak information and concentration calculations are given in Table VI, along with applicable AAS and INAA results for comparison. Standard values from run-to-run, and two duplicate samples in runs 2 and 4 suggest a good internal consistency to the XRF data and the comparisons to INAA and AAS results suggest a good methodto-method consistency.

As mentioned in the text, a question arose concerning the accuracy of the results, particularly for $\mathrm{SiO}_{2}$. The $\mathrm{SiO}_{2}$ concentration in the Reese Hill ore horizon is more than twice as great as the $\mathrm{SiO}_{2}$ concentration in ore horizons within nearby auger holes made by Corcoran and Libbey (1956). The analytical methods used for determination of a comparison of the techniques is not possible here. Their results are in agreement with generally reported silica values in other ore horizons of the Salem Hills as well as 
other Pacific Northwest bauxite areas so they are assumed to be reasonable values. Problems are likely in the XRF results of this report because only two or three standards were used to compute intensity versus concentration curves and, in the case of $\mathrm{SiO}_{2}$ and $\mathrm{TiO}_{2}$, the range in the concentration in the two standards was much less than that of the unknowns. Thus, curvature of the standard curve to which unknowns are compared, beyond the range of the standards concentration, was not properly considered in the data reduction. This could most certainly be a major source of error. $\mathrm{Fe}_{2} \mathrm{O}_{3}, \mathrm{Al}_{2} \mathrm{O}_{3}$ and $\mathrm{MnO}$ determinations were all based on three points with a relatively broad range of values, so error is expected to be less in these results.

One consideration that must now be raised is the fact that if the previously reported values are accurate and if similar materials were encountered in the three separate holes on Reese Hill, then $\mathrm{SiO}_{2}$ values should fall within the concentrations range of the standards used for this study. But, having ruled out this explanation, the most likely cause becomes matrix effects. The degree to which the XRF software used in these analyses deals with this problem is not known. 


\section{TABLE VII}

$X-R A Y$ FLUORESENCE DATA WITH COMPARISONS TO RESULTS OF OTHER ANALYTICAL METHODS

$$
\text { RUN \# } 1
$$

\begin{tabular}{|c|c|c|c|c|}
\hline $\mathrm{V} 1-\mathrm{l}$ & $\begin{array}{l}\text { Intensity } \\
\text { (CPS) }\end{array}$ & $\begin{array}{l}\text { Background } \\
\text { (CPS) }\end{array}$ & Concentration & INAA \\
\hline $\mathrm{Al}_{2} \mathrm{O}_{3}$ & 76.65 & 7.15 & $32.65 \pm 0.40$ & \\
\hline $\mathrm{SiO}_{2}$ & 3.78 & 8.06 & $1.21 \pm 0.08$ & \\
\hline $\mathrm{MnO}$ & 0.43 & 13.93 & $0.035 \pm 0.01$ & \\
\hline $\mathrm{Fe}_{2} \mathrm{O}_{3}$ & 1546.24 & 32.65 & $36.71 \pm 0.11$ & \\
\hline
\end{tabular}

EFT3

$\begin{array}{lrrrr}\mathrm{Al}_{2} \mathrm{O}_{3} & 61.49 & 7.86 & 25.70 \pm 0.37 & 21.48 \\ \mathrm{SiO}_{2} & 171.87 & 8.93 & 32.14 \pm 0.25 & \\ \mathrm{MnO} & 4.89 & 11.70 & 0.130 \pm 0.01 & \\ \mathrm{Fe}_{2} \mathrm{O}_{3} & 995.25 & 24.82 & 22.12 \pm 0.09 & 21.0 \pm .28\end{array}$

NBS 69

$\begin{array}{lrrr}\mathrm{Al}_{2} \mathrm{O}_{3} & 134.17 & 10.56 & 56.17 \pm 0.52 \\ \mathrm{SiO}_{2} & 31.45 & 11.09 & 6.30 \pm 0.13 \\ \mathrm{MnO} & 24.72 & 12.74 & 0.55 \pm 0.02 \\ \mathrm{Fe}_{2} \mathrm{O}_{3} & 360.62 & 22.12 & 5.31 \pm 0.05\end{array}$

TFB 23-28

$\begin{array}{lrrrr}\mathrm{Al}_{2} \mathrm{O}_{3} & 64.70 & 6.35 & 27.04 \pm 0.37 \\ \mathrm{SiO}_{2} & 109.04 & 7.80 & 20.575 \pm 0.21 \\ \mathrm{MnO} & 4.07 & 13.70 & 0.113 \pm 0.01 & \\ \mathrm{Fe}_{2} \mathrm{O}_{3} & 1185.78 & 29.58 & 27.16 \pm 0.09 & 27.7 \pm .57\end{array}$


Table VII (cont'd)

RHC Intensity Background

25-30 (CPS) (CPS)

Concentration INAA AAS

$\begin{array}{lrrrr}\mathrm{Al}_{2} \mathrm{O}_{3} & 82.08 & 6.93 & 34.33 \pm 0.41 \\ \mathrm{SiO}_{2} & 71.49 & 8.02 & 13.67 \pm 0.17 & \\ \mathrm{MnO} & 38.00 & 15.45 & 0.831 \pm 0.02 & \\ \mathrm{Fe}_{2} \mathrm{O}_{3} & 988.66 & 28.05 & 21.94 \pm 0.09 & 19.4 \pm .57\end{array}$

$\mathrm{RHC}$

$\underline{16-17}$

$\mathrm{Al}_{2} \mathrm{O}_{3}$

81.92

8.07

$34.26 \pm 0.42$

$\mathrm{SiO}_{2} \quad 78.84$

9.23

$15.02 \pm 0.18$

MnO 11.10

13.25

$0.262 \pm 0.01$

$\mathrm{Fe}_{2} \mathrm{O}_{3} \quad 971.24$

26.19

$21.48 \pm 0.08 \quad 22.0 \pm .43$

RHC

30-31B

$\mathrm{Al}_{2} \mathrm{O}_{3} \quad 37.15$

6.03

$15.49 \pm 0.29$

$\mathrm{SiO}_{2} \quad 205.35$

7.89

$38.30 \pm 0.27$

$\mathrm{MnO}$

2.91

9.33

$0.088 \pm 0.01$

$\mathrm{Fe}_{2} \mathrm{O}_{3} \quad 617.53$

19.41

$12.11 \pm 0.07$

- RHC

$31-35$

$\begin{array}{lrrr}\mathrm{Al}_{2} \mathrm{O}_{3} & 67.58 & 7.18 & 28.25 \pm 0.38 \\ \mathrm{SiO}_{2} & 19.43 & 8.88 & 4.09 \pm 0.11 \\ \mathrm{MnO} & 18.50 & 17.32 & 0.418 \pm 0.02 \\ \mathrm{Fe}_{2} \mathrm{O}_{3} 1408.73 & 33.52 & 33.06 \pm 0.10 & 31.9 \pm .57\end{array}$


Table VII (cont'd)

RHC Intensity Background

30-31C (CPS)

(CPS)

Concentration INAA AAS

$\begin{array}{llll}\mathrm{Al}_{2} \mathrm{O}_{3} & 42.58 & 5.86 & 17.71 \pm 0.31\end{array}$

$\mathrm{SiO}_{2} \quad 98.93 \quad 8.88 \quad 18.72 \pm 0.20$

Mno $\quad 1.77 \quad 11.98 \quad 0.064 \pm 0.01$

$\mathrm{Fe}_{2} \mathrm{O}_{3} \quad 1377.05 \quad 27.71 \quad 32.23 \pm 0.10 \quad 34.2 \pm .57$

RHC

$19-20$

$\begin{array}{lrrrr}\mathrm{Al}_{2} \mathrm{O}_{3} & 88.81 & 8.85 & 37.15 \pm 0.43 \\ \mathrm{SiO}_{2} & 72.95 & 10.10 & 13.94 \pm 0.18 & \\ \mathrm{MnO} & 8.59 & 12.47 & 0.208 \pm 0.01 & \\ \mathrm{Fe}_{2} \mathrm{O}_{3} & 890.65 & 26.51 & 19.35 \pm 0.08 & 19.6 \pm .43\end{array}$

RHC

$\underline{13-15}$

$\begin{array}{lrrrr}\mathrm{Al}_{2} \mathrm{O}_{3} & 67.24 & 6.97 & 28.11 \pm 0.38 \\ \mathrm{SiO}_{2} & 96.29 & 8.19 & 18.23 \pm 0.20 \\ \mathrm{MnO} & 4.52 & 12.12 & 0.122 \pm 0.01 & \\ \mathrm{Fe}_{2} \mathrm{O}_{3} & 1163.75 & 26.32 & 26.58 \pm 0.09 & 26.7 \pm .43\end{array}$

RHC 2-5

$\begin{array}{lrrrr}\mathrm{Al}_{2} \mathrm{O}_{3} & 66.16 & 7.66 & 27.65 \pm 0.38 \\ \mathrm{SiO}_{2} & 201.46 & 8.41 & 37.58 \pm 0.27 \\ \mathrm{MnO} & 2.59 & 10.71 & 0.081 \pm 0.01 & \\ \mathrm{Fe}_{2} \mathrm{O}_{3} & 739.42 & 22.99 & 15.34 \pm 0.07 & 14.6 \pm .28\end{array}$


Table VII (cont'd)

RUN \#2

$\begin{array}{lcccc}\text { VL-1 } & \begin{array}{l}\text { Intensity } \\ \text { (CPS) }\end{array} & \begin{array}{l}\text { Background } \\ \text { (CPS) }\end{array} & \text { Concentration } & \text { INAA }\end{array}$ AAS

EFT 3

$\begin{array}{lrrrr}\mathrm{Al}_{2} \mathrm{O}_{3} & 65.92 & 7.13 & 25.38 \pm 0.36 & 21.48 \\ \mathrm{SiO}_{2} & 183.35 & 7.97 & 32.51 \pm 0.25 & \\ \mathrm{MnO} & 4.86 & 11.31 & 0.130 \pm 0.01 & \\ \mathrm{Fe}_{2} \mathrm{O}_{3} & 976.88 & 26.91 & 22.08 \pm 0.09 & 21.0 \pm .28\end{array}$

NBS 69

$\begin{array}{lrrr}\mathrm{Al}_{2} \mathrm{O}_{3} & 143.23 & 11.07 & 56.20 \pm 0.51 \\ \mathrm{SiO}_{2} & 32.96 & 11.31 & 6.30 \pm 0.13 \\ \mathrm{MnO} & 24.92 & 12.42 & 0.550 \pm 0.01 \\ \mathrm{Fe}_{2} \mathrm{O}_{3} & 361.45 & 22.40 & 5.32 \pm 0.05\end{array}$

TFT 7
$\mathrm{Al}_{2} \mathrm{O}_{3}$
91.68
9.21
$35.65 \pm 0.42$
$\mathrm{SiO}_{2}$
192.05
9.75
$34.02 \pm 0.25$
MnO
1.22
9.51
$0.054 \pm 0.01$
$\mathrm{Fe}_{2} \mathrm{O}_{3} \quad 464.44 \quad 22.19$
$8.13 \pm 0.067 .3 \pm .76$ 
Table VII (cont'd)

TFB Intensity Background

$\begin{array}{llll}3-8 & \text { (CPS) } & \text { (CPS) } & \text { Concentraton } \\ \mathrm{Al}_{2} \mathrm{O}_{3} & 70.50 & 7.95 & 27.20 \pm 0.37\end{array}$

$\begin{array}{llll}\mathrm{SiO}_{2} & 181.35 & 8.62 & 32.16 \pm 0.25\end{array}$

Mno $\quad 3.30 \quad 11.59 \quad 0.097 \pm 0.01$

$\mathrm{Fe}_{2} \mathrm{O}_{3} \quad 903.32 \quad 26.94 \quad 20.08 \pm 0.08 \quad 17.9 \pm .43$

TFB

$\underline{16-17}$

$\begin{array}{lrrrr}\mathrm{Al}_{2} \mathrm{O}_{3} & 73.09 & 7.54 & 28.24 \pm 0.37 \\ \mathrm{SiO}_{2} & 74.71 & 9.32 & 13.58 \pm 0.17 \\ \mathrm{MnO} & 6.23 & 12.89 & 0.159 \pm 0.01 & \\ \mathrm{Fe}_{2} \mathrm{O}_{3} & 1206.41 & 28.71 & 28.33 \pm 0.10 & 25.0 \pm .43\end{array}$

TFB

$\underline{28-32}$

$\begin{array}{lrrrr}\mathrm{Al}_{2} \mathrm{O}_{3} & 69.55 & 7.67 & 26.82 \pm 0.37 \\ \mathrm{SiO}_{2} & 144.67 & 9.27 & 25.77 \pm 0.22 & \\ \mathrm{MnO} & 7.48 & 12.54 & 0.185 \pm 0.01 & \\ \mathrm{Fe}_{2} \mathrm{O}_{3} & 111.97 & 27.75 & 25.76 \pm 0.09 & 26.2 \pm .57\end{array}$

TFB

$\underline{32-37}$

$\begin{array}{lrrrr}\mathrm{Al}_{2} \mathrm{O}_{3} & 59.69 & 7.55 & 22.89 \pm 0.34 \\ \mathrm{SiO}_{2} & 136.62 & 8.67 & 24.36 \pm 0.22 \\ \mathrm{MnO} & 6.77 & 12.93 & 0.270 \pm 0.01 & \\ \mathrm{Fe}_{2} \mathrm{O}_{3} & 1120.25 & 24.44 & 25.99 \pm 0.09 & 27.2 \pm .57\end{array}$


Table VII (cont'd)

TFB Intensity Background

$\frac{50-52}{\mathrm{Al}_{2} \mathrm{O}_{3}} \frac{\text { (CPS) }}{63.69} \frac{\text { (CPS) }}{6.52} \frac{\text { Concentration }}{24.49 \pm 0.35}$

$\mathrm{SiO}_{3} \quad 141.34 \quad 7.76 \quad 25.19 \pm 0.22$

MnO $9.03 \quad 12.43 \quad 0.217 \pm 0.01$

$\mathrm{Fe}_{2} \mathrm{O}_{3} \quad 1078.11 \quad 26.37 \quad 24.84 \pm 0.09 \quad 24.0 \pm .43$

TFT 1

$\begin{array}{lrrrr}\mathrm{Al}_{2} \mathrm{O}_{3} & 54.29 & 5.53 & 20.74 \pm 0.32 \\ \mathrm{SiO}_{2} & 139.99 & 6.89 & 24.95 \pm 0.22 \\ \mathrm{MnO} & 7.99 & 12.45 & 0.195 \pm 0.01 \\ \mathrm{Fe}_{2} \mathrm{O}_{3} & 1213.99 & 27.16 & 28.54 \pm 0.10 & 27.5 \pm .57\end{array}$

TFT 2

$\mathrm{Al}_{2} \mathrm{O}_{3} \quad 61.73 \quad 6.26 \quad 23.70 \pm 0.34$

$\begin{array}{llll}\mathrm{SiO}_{3} & 164.28 & 7.58 & 29.18 \pm 0.23\end{array}$

Mno $\quad 8.49 \quad 11.96 \quad 0.206 \pm 0.01$

$\mathrm{Fe}_{2} \mathrm{O}_{3} \quad 1061.05 \quad 26.10 \quad 24.37 \pm 0.09 \quad 24.4 \pm .43$

TFT 3

$\begin{array}{lrrrr}\mathrm{Al}_{2} \mathrm{O}_{3} & 58.57 & 6.36 & 22.45 \pm 0.34 \\ \mathrm{SiO}_{2} & 164.38 & 7.54 & 29.20 \pm 0.23 \\ \mathrm{MnO} & 8.76 & 12.36 & 0.212 \pm 0.01 & \\ \mathrm{Fe}_{2} \mathrm{O}_{3} & 1096.24 & 28.24 & 25.33 \pm 0.09 & 25.0 \pm .43\end{array}$


Table VII (cont'd)

\section{RUN \#3}

\begin{tabular}{lrrr}
$\mathrm{VL}-1$ & $\begin{array}{l}\text { Intensity } \\
\text { (CPS) }\end{array}$ & $\begin{array}{l}\text { Background } \\
\text { (CPS) }\end{array}$ & $\frac{\text { Concentration INAA }}{32.06 \pm 0.40}$ \\
\cline { 1 - 2 } $\mathrm{Al}_{2} \mathrm{O}_{3}$ & 77.92 & 7.77 & AAS \\
$\mathrm{SiO}_{2}$ & 2.43 & 9.01 & $1.21 \pm 0.09$ \\
$\mathrm{MnO}$ & 0.00 & 14.95 & $0.050 \pm 0.01$ \\
$\mathrm{Fe}_{2} \mathrm{O}_{3}$ & 1451.16 & 33.12 & $36.52 \pm 0.11$
\end{tabular}

EFT 3

$\begin{array}{lrrrr}\mathrm{Al}_{2} \mathrm{O}_{3} & 62.71 & 7.05 & 25.69 \pm 0.37 & 21.48 \\ \mathrm{SiO}_{2} & 176.96 & 8.62 & 34.74 \pm 0.27 & \\ \mathrm{MnO} & 3.92 & 11.24 & 0.130 \pm 0.01 & \\ \mathrm{Fe}_{2} \mathrm{O}_{3} & 957.18 & 25.58 & 22.44 \pm 0.09 & 21.0 \pm .28\end{array}$

NBS 69

$\begin{array}{lrrr}\mathrm{Al}_{2} \mathrm{O}_{3} & 135.56 & 13.28 & 56.17 \pm 0.53 \\ \mathrm{SiO}_{2} & 28.92 & 13.61 & 6.30 \pm 0.14 \\ \mathrm{MnO} & 24.45 & 12.38 & 0.550 \pm 0.01 \\ \mathrm{Fe}_{2} \mathrm{O}_{3} & 351.54 & 20.91 & 5.18 \pm 0.06\end{array}$

PHB

15-17

$\begin{array}{lrrrr}\mathrm{Al}_{2} \mathrm{O}_{3} & 70.25 & 7.43 & 28.85 \pm 0.39 \\ \mathrm{SiO}_{2} & 122.86 & 9.01 & 24.35 \pm 0.23 \\ \mathrm{MnO} & 5.39 & 11.89 & 0.160 \pm 0.01 & \\ \mathrm{Fe}_{2} \mathrm{O}_{3} & 955.67 & 26.58 & 22.39 \pm 0.09 & 22.6 \pm .28\end{array}$


Table VII (cont'd)

PHB Intensity Background

$\frac{8-13}{\mathrm{Al}_{2} \mathrm{O}_{3}} \frac{\text { (CPS) }}{74.35} \frac{\text { (CPS) }}{6.31} \frac{\text { Concentration }}{30.56 \pm 0.39}$

$\begin{array}{llll}\mathrm{SiO}_{2} & 63.18 & 8.32 & 12.88 \pm 0.17\end{array}$

Mno $\quad 3.44 \quad 12.62 \quad 0.120 \pm 0.01$

$\mathrm{Fe}_{2} \mathrm{O}_{3} \quad 1238.20 \quad 26.99 \quad 30.45 \pm 0.10 \quad 21.4 \pm .28$

PHB

$\underline{20-22}$

$\begin{array}{llll}\mathrm{Al}_{2} \mathrm{O}_{3} & 67.15 & 7.90 & 27.55 \pm 0.38\end{array}$

$\mathrm{SiO}_{2} \quad 145.34 \quad 8.84 \quad 28.66 \pm 0.25$

MnO $\quad 5.68 \quad 11.74 \quad 0.166 \pm 0.01$

$\mathrm{Fe}_{2} \mathrm{O}_{3} \quad 944.72 \quad 25.28 \quad 22.08 \pm 0.09 \quad 21.4 \pm .28$

PHB

$\underline{25-27}$

$\begin{array}{lrrrr}\mathrm{Al}_{2} \mathrm{O}_{3} & 74.13 & 7.85 & 30.47 \pm 0.40 \\ \mathrm{SiO}_{2} & 154.90 & 8.62 & 30.50 \pm 0.25 & \\ \mathrm{MnO} & 7.70 & 10.65 & 0.207 \pm 0.01 & \\ \mathrm{Fe}_{2} \mathrm{O}_{3} & 721.22 & 21.45 & 15.71 \pm 0.08 & 15.6 \pm .26\end{array}$

\section{PHB}

$\underline{31-32}$

$\begin{array}{lrrrr}\mathrm{Al}_{2} \mathrm{O}_{3} & 63.37 & 6.80 & 25.97 \pm 0.37 \\ \mathrm{SiO}_{2} & 132.95 & 8.06 & 26.28 \pm 0.23 & \\ \mathrm{MnO} & 4.65 & 11.62 & 0.145 \pm 0.01 & \\ \mathrm{Fe}_{2} \mathrm{O}_{3} & 1014.27 & 26.86 & 24.06 \pm 0.09 & 24.6 \pm .28\end{array}$


Table VII (cont'd)

\begin{tabular}{|c|c|c|c|c|}
\hline PHN 1 & $\begin{array}{l}\text { Intensity } \\
\text { (CPS) }\end{array}$ & $\begin{array}{l}\text { Background } \\
\text { (CPS) }\end{array}$ & Concentration & INAA \\
\hline $\mathrm{Al}_{2} \mathrm{O}_{3}$ & 120.97 & 10.80 & $50.07 \pm 0.50$ & \\
\hline $\mathrm{SiO}_{2}$ & 5.51 & 11.74 & $1.80 \pm 0.10$ & \\
\hline MnO & 2.96 & 11.80 & $0.110 \pm 0.01$ & \\
\hline $\mathrm{Fe}_{2} \mathrm{O}_{3}$ & 703.96 & 23.75 & $15.22 \pm 0.08$ & $10.7 \pm .23$ \\
\hline \multicolumn{5}{|c|}{ PHB 2-3 } \\
\hline $\mathrm{Al}_{2} \mathrm{O}_{3}$ & 63.18 & 6.51 & $25.89 \pm 0.37$ & \\
\hline $\mathrm{SiO}_{2}$ & 170.75 & 7.71 & $33.54 \pm 0.26$ & \\
\hline MnO & 3.63 & 12.29 & $0.124 \pm 0.01$ & \\
\hline $\mathrm{Fe}_{2} \mathrm{O}_{3}$ & 916.32 & 27.39 & $21.27 \pm 0.09$ & $21.7 \pm .28$ \\
\hline
\end{tabular}

EFT 1

$\begin{array}{lrrrr}\mathrm{Al}_{2} \mathrm{O}_{3} & 88.79 & 9.23 & 36.60 \pm 0.43 \\ \mathrm{SiO}_{2} & 58.76 & 9.97 & 12.03 \pm 0.17 \\ \mathrm{MnO} & 2.23 & 12.08 & 0.095 \pm 0.01 & \\ \mathrm{Fe}_{2} \mathrm{O}_{3} & 956.43 & 27.42 & 22.30 \pm 0.09 & 21.3 \pm .26\end{array}$

EFT 4

$\begin{array}{lrrrr}\mathrm{Al}_{2} \mathrm{O}_{3} & 59.01 & 7.44 & 24.14 \pm 0.36 \\ \mathrm{SiO}_{2} & 171.80 & 8.54 & 33.75 \pm 0.26 \\ \mathrm{MnO} & 3.24 & 11.67 & 0.116 \pm 0.01 & \\ \mathrm{Fe}_{2} \mathrm{O}_{3} & 905.35 & 25.46 & 20.96 \pm 0.09 & 20.3 \pm .28\end{array}$


Table VII (cont'd)

$$
\text { RUN \#4 }
$$

\begin{tabular}{|c|c|c|c|c|}
\hline$\underline{V L-1}$ & $\begin{array}{l}\text { Intensity } \\
\text { (CPS) }\end{array}$ & $\begin{array}{l}\text { Backqround } \\
\text { (CPS) }\end{array}$ & Concentration & INAA \\
\hline $\mathrm{Al}_{2} \mathrm{O}_{3}$ & 80.77 & 7.59 & $31.83 \pm 0.40$ & \\
\hline $\mathrm{SiO}_{2}$ & 2.76 & 8.71 & $1.21 \pm 0.08$ & \\
\hline MnO & 0.00 & 13.32 & $0.066 \pm 0.01$ & \\
\hline $\mathrm{Fe}_{2} \mathrm{O}_{3}$ & 1489.14 & 32.36 & $36.73 \pm 0.11$ & \\
\hline
\end{tabular}

EFT 3

\begin{tabular}{|c|c|c|c|c|}
\hline $\mathrm{Al}_{2} \mathrm{O}_{3}$ & 66.54 & 6.94 & $25.95 \pm 0.37$ & 21.48 \\
\hline $\mathrm{SiO}_{2}$ & 182.16 & 8.06 & $31.40 \pm 0.24$ & \\
\hline MnO & 3.19 & 12.51 & $0.13 \pm 0.01$ & 0.13 \\
\hline $\mathrm{Fe}_{2} \mathrm{O}_{3}$ & 957.27 & 27.69 & $22.07 \pm 0.09$ & $21.0+.28$ \\
\hline
\end{tabular}

NBS 69

$\begin{array}{lrrr}\mathrm{Al}_{2} \mathrm{O}_{3} & 138.57 & 11.47 & 56.14 \pm 0.53 \\ \mathrm{SiO}_{2} & 33.00 & 11.66 & 6.30 \pm 0.13 \\ \mathrm{MnO} & 24.26 & 13.31 & 0.55 \pm 0.01 \\ \mathrm{Fe}_{2} \mathrm{O}_{3} & 349.67 & 21.96 & 5.33 \pm 0.05\end{array}$

TFB

72-77

\begin{tabular}{|c|c|c|c|c|}
\hline $\mathrm{Al}_{2} \mathrm{O}_{3}$ & 63.75 & 7.14 & $24.79 \pm 0.37$ & 23.64 \\
\hline $\mathrm{SiO}_{2}$ & 151.70 & 8.28 & $26.28 \pm 0.22$ & \\
\hline Mno & 9.41 & 12.15 & $0.254 \pm 0.01$ & 0.27 \\
\hline $\mathrm{Fe}_{2} \mathrm{O}_{3}$ & 1021.35 & 26.11 & $23.84 \pm 0.09$ & $24.9 \pm .43$ \\
\hline
\end{tabular}


Table VII (cont'd)

\begin{tabular}{|c|c|c|c|c|c|}
\hline $\begin{array}{l}\text { TFB } \\
8-12 \\
\end{array}$ & $\begin{array}{l}\text { Intensity } \\
\text { (CPS) }\end{array}$ & $\begin{array}{l}\text { Background } \\
\text { (CPS) }\end{array}$ & Concentration & INAA & $\underline{\text { AAS }}$ \\
\hline $\mathrm{Al}_{2} \mathrm{O}_{3}$ & 72.68 & 7.41 & $28.49 \pm 0.39$ & & 27.0 \\
\hline $\mathrm{SiO}_{2}$ & 149.45 & 8.41 & $25.90 \pm 0.22$ & & \\
\hline MnO & 0.00 & 11.58 & $0.066 \pm 0.01$ & & 0.07 \\
\hline $\mathrm{Fe}_{2} \mathrm{O}_{3}$ & 949.23 & 25.56 & $21.85 \pm 0.09$ & $21.3 \pm .28$ & \\
\hline
\end{tabular}

PHB

$\underline{13-15}$

$\begin{array}{lrrrr}\mathrm{Al}_{2} \mathrm{O}_{3} & 68.74 & 7.89 & 28.49 \pm 0.39 \\ \mathrm{SiO}_{2} & 36.49 & 9.88 & 25.90 \pm 0.22 & \\ \mathrm{MnO} & 5.40 & 13.55 & 0.066 \pm 0.01 & \\ \mathrm{Fe}_{2} \mathrm{O}_{3} & 1335.69 & 29.77 & 21.85 \pm 0.09 & 34.3 \pm .43\end{array}$

PHB

7-8

$\mathrm{Al}_{2} \mathrm{O}_{3} \quad 77.42 \quad 8.06 \quad 26.86 \pm 0.38$

$\mathrm{SiO}_{2} \quad 101.43 \quad 9.45 \quad 6.89 \pm 0.13$

MnO $2.86 \quad 12.96 \quad 0.174 \pm 0.01$

$\mathrm{Fe}_{2} \mathrm{O}_{3} 1152.81 \quad 27.82 \quad 32.50 \pm 0.10 \quad 29.2 \pm .28$

EFT 2

$\begin{array}{lrrrr}\mathrm{Al}_{2} \mathrm{O}_{3} & 63.43 & 7.33 & 30.45 \pm 0.40 \\ \mathrm{SiO}_{2} & 180.48 & 8.49 & 17.82 \pm 0.18 & \\ \mathrm{MnO} & 5.27 & 12.21 & 0.123 \pm 0.01 & \\ \mathrm{Fe}_{2} \mathrm{O}_{3} & 917.47 & 27.86 & 27.46 \pm 0.10 & 20.3 \pm .24\end{array}$


Table VII (cont'd)

\begin{tabular}{|c|c|c|c|c|c|}
\hline $\begin{array}{l}\text { RHC } \\
40-45 \\
\end{array}$ & $\begin{array}{l}\text { Intensity } \\
\text { (CPS) }\end{array}$ & $\begin{array}{l}\text { Background } \\
\text { (CPS) }\end{array}$ & Concentration & INAA & AAS \\
\hline $\mathrm{Al}_{2} \mathrm{O}_{3}$ & 98.87 & 9.50 & $39.32 \pm 0.45$ & & 33.56 \\
\hline $\mathrm{SiO}_{2}$ & 127.92 & 10.18 & $22.27 \pm 0.20$ & & \\
\hline Mno & 3.12 & 10.43 & $0.128 \pm 0.01$ & & 0.09 \\
\hline $\mathrm{Fe}_{2} \mathrm{O}_{3}$ & 719.18 & 24.64 & $15.51 \pm 0.08$ & $13.6 \pm .14$ & \\
\hline
\end{tabular}

TFT 4

$\begin{array}{lrrrr}\mathrm{Al}_{2} \mathrm{O}_{3} & 64.47 & 6.49 & 25.09 \pm 0.36 \\ \mathrm{SiO}_{2} & 181.18 & 7.37 & 31.24 \pm 0.24 & \\ \mathrm{MnO} & 4.24 & 12.35 & 0.151 \pm 0.01 & \\ \mathrm{Fe}_{2} \mathrm{O}_{3} & 996.81 & 27.44 & 23.16 \pm 0.09 & 25.4 \pm .57\end{array}$

TFT 2

$\begin{array}{lrrrr}\mathrm{Al}_{2} \mathrm{O}_{3} & 61.85 & 6.26 & 24.01 \pm 0.36 \\ \mathrm{SiO}_{2} & 163.43 & 7.28 & 28.25 \pm 0.22 \\ \mathrm{MnO} & 6.93 & 11.83 & 0.204 \pm 0.01 & \\ \mathrm{Fe}_{2} \mathrm{O}_{3} & 1021.52 & 27.31 & 23.84 \pm 0.09 & 24.4 \pm .43\end{array}$

TFT 1
$\mathrm{Al}_{2} \mathrm{O}_{3} \quad 50.12$
7.52
$19.16 \pm 0.33$
$\mathrm{SiO}_{2} \quad 134.68$
9.23
$23.41 \pm 0.21$
Mno
8.78
12.31
$0.241 \pm 0.01$
$\mathrm{Fe}_{2} \mathrm{O}_{3} 1172.60$
26.71
$28.01 \pm 0.10 \quad 27.5 \pm .57$ 